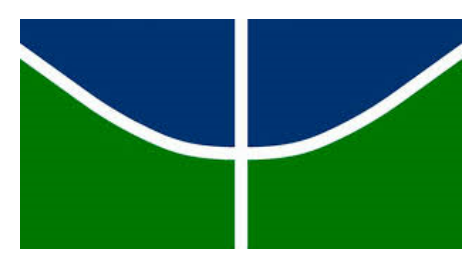

UNIVERSIDADE DE BRASÍLIA

Faculdade de Agronomia e Medicina Veterinária Programa de Pós Graduação em Saúde Animal

\title{
ALTERAÇÕES NEOPLÁSICAS E NÃO NEOPLÁSICAS DAS MÃOS E DOS PÉS DE CÃES (2003-2016)
}

\author{
LORENA FERREIRA SILVA
}

DISSERTAÇÃO DE MESTRADO EM SAÚDE ANIMAL

BRASÍLIA/DF

FEVEREIRO/2017 


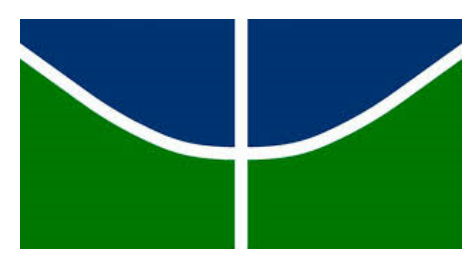

UNIVERSIDADE DE BRASÍLIA

Faculdade de Agronomia e Medicina Veterinária Programa de Pós Graduação em Saúde Animal

\title{
ALTERAÇÕES NEOPLÁSICAS E NÃO NEOPLÁSICAS DAS MÃOS E DOS PÉS DE CÃES (2003-2016)
}

\author{
LORENA FERREIRA SILVA
}

ORIENTADOR: FABIANO JOSÉ FERREIRA DE SANT'ANA

DISSERTAÇÃO DE MESTRADO EM SAÚDE ANIMAL

PUBLICAÇÃO: 135/2017

BRASÍLIA/DF

FEVEREIRO/2017 


\title{
ALTERAÇÕES NEOPLÁSICAS E NÃO NEOPLÁSICAS DAS MÃOS E DOS PÉS DE CÃES (2003-2016).
}

\author{
LORENA FERREIRA SILVA
}

DISSERTAÇÃO DE MESTRADO SUBMETIDA AO PROGRAMA DE PÓS-GRAdUAÇÃo EM SAÚde ANIMAL, COMO PARTE DOS REQUISITOS NECESSÁRIOS À OBTENÇÃo DO GRAU DE MESTRE EM SAÚDE ANIMAL.

APROVADA POR:

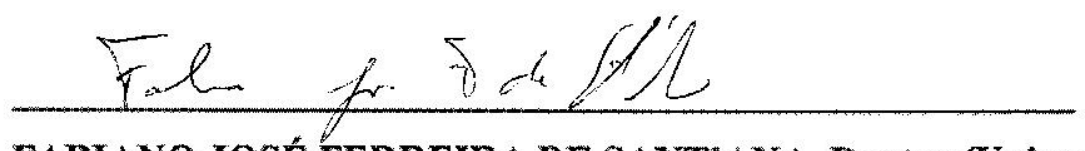

FABIANO JOSÉ FERREIRA DE SANT'ANA, Doutor (Universidade de Brasilia) (ORIENTADOR)

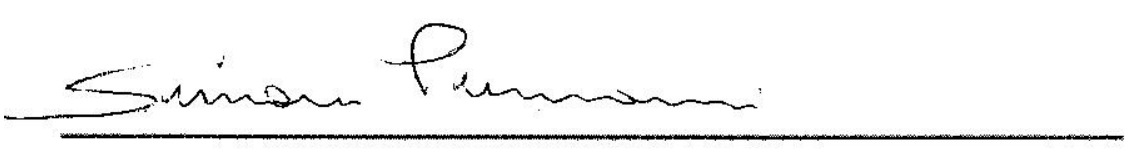

SIMONE PERECMANIS, Doutora (Universidade de Brasília) (EXAMINADOR INTERNO)

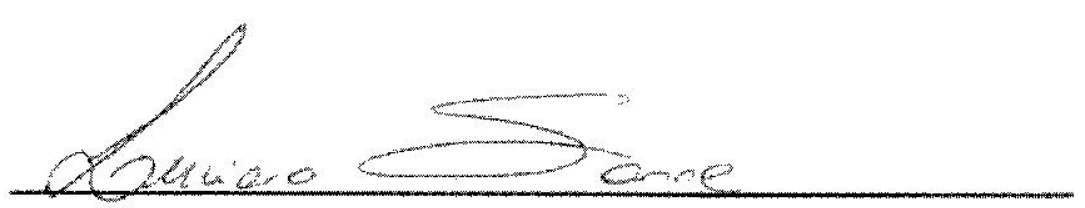

LUCIANA SONNE, Doutora (Universidade Federal do Rio Grande do Sul) (EXAMINADOR EXTERNO)

BRASÍLIA/DF, 17 de FEVEREIRO de 2017 


\section{REFERÊNCIA BIBLIOGRÁFICA E CATALOGAÇÃO}

SILVA, L.F. Alterações neoplásicas e não neoplásicas das mãos e dos pés de cães (2003-2016). Brasília: Faculdade de Agronomia e Medicina Veterinária, Universidade de Brasília, 2017, 118p. Dissertação de Mestrado.

Documento formal, autorizando reprodução desta dissertação de Mestrado para empréstimo ou comercialização, exclusivamente para fins acadêmicos; foi passado pelo autor à Universidade de Brasília e acha-se arquivado na secretaria do Programa. O autor reserva para si os outros direitos autorais, de publicação. Nenhuma parte desta dissertação de mestrado pode ser reproduzida sem a autorização por escrito do autor. Citações são estimuladas, desde que citada a fonte.

\section{FICHA CATALOGRÁFICA}

Silva, Lorena Ferreira

Alterações neoplásicas e não neoplásicas das mãos e dos pés de cães (2003-2016). / Lorena Ferreira Silva; orientação de Fabiano José Ferreira de Sant'Ana - Brasília, 2017. 115p. : il.

Dissertação de Mestrado (M) - Universidade de Brasília / Faculdade de Agronomia e Medicina Veterinária, 2017.

1. Doenças de cães. 2. Dermatopatologia. 3. Podologia. 4. Pododermatite. 5. Carcinoma de células escamosas. I. Sant'Ana, F.J.F. II. Estudo retrospectivo de alterações neoplásicas e não neoplásicas das mãos e dos pés de cães (2003-2016). 


\section{RESUMO}

As mãos e os pés são alvos frequentes de lesões em cães, incluindo lesões neoplásicas e não neoplásicas. Embora alguns estudos detalhem a prevalência e a caracterização clínicopatológica de alterações digitais em cães em alguns países, trabalhos similares não tem sido realizado no Brasil. O objetivo do presente trabalho foi realizar estudo retrospectivo para caracterizar as alterações tumoriformes que afetam as mãos e os pés de cães. Foram analisados 105 alterações tumoriformes desta região em cães no período de 2003 a 2016. As lesões mais comuns foram neoplasmas (62,9\%), seguidos de processos inflamatórios $(19 \%)$ e de outras alterações $(18,1 \%)$. Dentre os neoplasmas, $40,9 \%$ eram mesenquimais, $39,4 \%$ eram epiteliais e 19,7\% de células redondas. Todos os neoplasmas de células redondas e a maioria dos neoplasmas epiteliais e mesenquimais foram malignos. Fêmeas e machos foram acometidos similarmente. As raças mais afetadas foram Labrador Retriever, Schnauzer, Teckel, sem raça definida, Pastor Alemão, Rottweiler e Pit Bull. Fila, Pit Bull e Schnauzer foram as raças mais afetadas por neoplasmas mesenquimais, epiteliais e de células redondas, respectivamente. Labrador Retriever foi a raça mais diagnosticada com inflamações e Teckel, Labrador Retriever e SRD os que mais tiveram outras alterações. A idade e o peso médio foram de 8,4 anos e $28,5 \mathrm{~kg}$, respectivamente. O diâmetro médio das tumorações foi de $2,5 \mathrm{~cm}$, e os neoplasmas apresentavam as maiores médias. A pelagem com o maior número de alterações foi a amarela. A maioria das biópsias eram incisionais e a maior parte das amostras provenientes de amputação era neoplásica. $\mathrm{O}$ membro torácico direito foi o mais afetado, enquanto que o dígito foi a principal estrutura anatômica lesada. Os neoplasmas mais comuns foram o carcinoma de células escamosas, seguido do mastocitoma, melanoma e sarcoma indiferenciado. Dos casos de inflamação, metade afetava o folículo piloso e adjacências e o infiltrado era predominantemente piogranulomatoso ou linfoplasmocítico. Cisto folicular, calcinose circunscrita, acrocordoma e hiperqueratose foram as principais alterações não neoplásicas e não inflamatórias diagnosticadas.

Palavras-chave: Doenças de cães. Dermatopatologia. Podologia. Pododermatite. Carcinoma de células escamosas. 


\begin{abstract}
Despite the fact that neoplastic and non-neoplastic lesions commonly affect hands and feet of dogs, there are few studies regarding these lesions in Brazil. The objective of this manuscript was to do a retrospective study to characterize the tumoriform changes that affect these areas in dogs. One-hundred-five cases of dogs, from 2003 to 2016, with tumoriform lesions in hands and feet were analyzed on histopathology. The lesions frequently found were neoplasms (62.9\%), followed by inflammation (19\%) and other changes (no inflammatory and no neoplastic) (18.1\%). The neoplactic changes were $40.9 \%$ mesenchymal, 39.4\% epithelial, and $19.7 \%$ round cells. All round cells neoplasia and the most of the epithelial and mesenchymal tumors were malignant. Female and male dogs were similarly affected. Labrador Retriever (11.9\%), Schnauzer (9.9\%), Teckel (8.9\%), mongrel (8.9\%), German Shepherd (8.9\%), Rottweiler (8.9\%), and Pit Bull (8.9\%) were more frequently affected. Fila Brasileiro (aka Brazilian mastiff), Pit Bull and Schnauzer were the main breeds injured by mesenchymal, epithelial, and round cells neoplasms, respectively. Labrador Retriever was more frequently diagnosed with inflammation. Other no inflammatory and no neoplastic changes were observed more commonly in Teckel, Labrador Retriever, and mongrel dogs. Medium age and weight were 8.4 years and 28.5 $\mathrm{kg}$, respectively. Medium diameter of the tumoriform lesions was $2.5 \mathrm{~cm}$ and neoplasms represented higher averages. Lesions were noted mainly in dogs with yellow coat (24\%). Most biopsies samples (56.4\%) were incisional, and amputations (85.3\%) were mostly from cases with neoplastic changes. Right forelimb was the most affected limb, and digits were the main injured anatomic structures. Squamous cell carcinoma was the most (14.2\%) commonly diagnosed neoplasm, followed by mastocytoma (7.6\%), melanoma (7.6\%), and undifferentiated sarcoma (7.6\%). In half of the inflammatory cases, the lesion was centered in hair follicle and surrounding dermis. The inflammatory infiltrate was predominantly piogranulomatous or lymphoplasmacytic. Follicular cyst, calcinosis circumscripta, acrochordons and hyperkeratosis were the main non neoplastic and non-inflammatory changes.
\end{abstract}

Keywords: Diseases of dogs. Dermatopathology. Podology. Pododermatitis. Squamous cell carcinoma. 


\section{LISTA DE ILUSTRAÇÕES}

\section{Capítulo 4}

Figura 1 - Histologia em $1^{\circ}$ e $2^{\circ}$ dígito de um cão, fêmea, Rottweiler, com CCE. HE. A. Observa-se os blocos de células epiteliais em meio a pequeno estroma fibrovascular. Obj. 10X B. A neoplasia apresenta-se pleomórfica, com necrose celular moderada. Obj. 10X C. Observa-se formação de "pérolas córneas" (asterisco) em meio a blocos de células neoplásicas. Obj. 10X D. Infiltração da neoplasia acometendo o tecido ósseo (terceira falange) (seta). Obj. 20X.

Figura 2 - A. Histologia de um digito de um cão Golden, macho. A. Observa-se uma neoplasia de células mesenquimais sem pigmentação. HE, Obj, 20X. B. As células neoplásicas, predominantemente da região da derme superficial, apresentam marcação citoplasmática. Imuno-histoquímica Melan-A, cromógeno AEC. Obj. 20X.

Figura 3 - Aspectos histológicos e imuno-histoquímicos de mastocitoma digital afetando o dígito do membro torácico direito de um cão Bulldog, macho A. Nota-se proliferação neoplásica de células redondas, densamente celular, com ausência de grânulos citoplasmáticos. HE, Obj. 20X. B. Visualiza-se ausência de grânulos metacromáticos no citoplasma das células neoplásicas. Azul de toluidina, Obj. 20X. C e D. Observa-se células redondas neoplásicas com imunomarcação citoplasmática moderada. Imuno-histoquímica CD117, cromógeno DAB. Obj. 10X (C) e 20X (D).

Figura 4 - Neoplasma de células redondas indiferenciado diagnosticado no dígito (altura da falange distal) de uma cadela Boxer. Visualiza-se corte longitudinal de massa neoplásica esbranquiçada e moderadamente delimitada (asterisco) na região caudal do dígito, próximo a falange distal (seta). Proveniente de amputação de um dígito.

Figura 5 - Osteossarcoma osteoblático digital detectado na região da falange proximal em uma cadela Tekel. Massa neoplásica esbranquiçada obtida em amputação de um dígito, cortada longitudinalmente. Nota-se a falange distal acometida pela neoplasia (seta), e a unha irregular e lascada (asterisco). 


\section{LISTA DE TABELAS}

\section{Capítulo 4}

Tabela 1 - Painel imuno-histoquímico utilizado, dependendo da suspeita histológica, para avaliação de lesões neoplásicas das mãos e dos pés de cães.

Tabela 2 - Distribuição e frequência de 105 alterações tumoriformes nas mãos e nos pés de cães, quanto ao tipo de lesão e comportamento.

Tabela 3 - Idade de 86 cães afetados por alterações tumoriformes nas mãos e nos pés (2003-2016).

Tabela 4 - Quantidade de alterações tumoriformes nas mãos e pés de cães obtidas por biópsia com ou sem amputação.

Tabela 5 - Frequência e localização anatômica de 105 alterações tumoriformes nas mãos e nos pés de cães.

Tabela 6 - Frequência e diagnósticos morfológicos de 105 alterações tumoriformes observadas nas mãos e nos pés de cães. 


\section{SUMÁRIO}

1. INTRODUÇÃOO 1

1.1 OBJETIVOS 2

2. REFERENCIAL TEÓRICO 3

2.1 ANATOMIA BÁSICA DAS MÃOS E DOS PÉS 3

2.1.1 Anatomia básica das mãos 3

2.1.2 Anatomia básica dos pés 5

$\begin{array}{lll}2.1 .3 & \text { Coxim } & 7\end{array}$

2.1.4 Unha 7

2.1.5 Demais informações de relevância anatômica 8

2.2 HISTOLOGIA BÁSICA DAS PATAS 8

2.2.1 Pele 8

2.2.1.1 Epiderme 8

2.2.1.2 Derme 11

2.2.1.3 Pelo e folículo piloso 11

2.2.1.4 Músculo eretor do pelo 13

$\begin{array}{lll}2.2 .1 .5 & \text { Glândulas } & 14\end{array}$

2.2.1.6 Hipoderme 15

2.2.1.7 Demais estruturas da pele 15

2.2.1.8 Particularidades do coxim 16

2.2.2 Unha 17

2.3 PRINCIPAIS ALTERAÇÕES DA REGIÃO DA MÃO E DO PÉ 18

$\begin{array}{lll}2.3 .1 & \text { Alterações neoplásicas } & 18\end{array}$

2.3.1.1 Neoplasmas epiteliais 19

2.3.1.1.1 Adenoma apócrino 19

2.3.1.1.2 Adenoma sebáceo 20

2.3.1.1.3 Carcinoma de células basais $\quad 21$

2.3.1.1.4 Carcinoma de células escamosas $\quad 21$

2.3.1.1.5 Carcinoma sebáceo 24

2.3.1.1.6 Epitelioma sebáceo $\quad 25$

2.3.1.1.7 Tricoepitelioma 26

$\begin{array}{lll}\text { 2.3.1.2 Neoplasmas mesenquimais } & 27\end{array}$ 
2.3.1.2.1 Hemangioma

2.3.1.2.2 Hemangiossarcoma $\quad 29$

2.3.1.2.3 Lipoma 31

2.3.1.2.4 Melanoma $\quad 32$

2.3.1.2.5 Osteossarcoma

2.3.1.2.6 Sarcoma histiocítico 37

2.3.1.2.7 Tumor de bainha de nervo periférico 40

2.3.1.2.8 Tumores da parede perivascular canina 41

2.3.1.3 Neoplasmas de células redondas 44

2.3.1.3.1 Histiocitoma 44

2.3.1.3.2 Mastocitoma 45

2.3.1.3.3 Plasmocitoma 48

2.3.2 Pododermatites 50

2.3.2.1 Principais pododermatites bacterianas $\quad 52$

2.3.2.2 Principais pododermatites fúngicas $\quad 53$

2.3.2.3 Principais pododermatites parasitárias 54

2.3.2.4 Demais causas de pododermatites de maior importância 58

2.3.3 Outras alterações $\quad 62$

2.3.3.1 Acrocordón $\quad 62$

2.3.3.2 Calcinose circunscrita 62

2.3.3.3 Cisto apócrino $\quad 64$

2.3.3.4 Cisto folicular 64

2.3.3.5 Comedão 65

2.3.3.6 Hamartoma 66

2.3.3.7 Hiperplasia sebácea 66

2.3.3.8 Hiperqueratose $\quad 67$

3. REFERÊNCIAS 69

4. ARTIGO CIENTÍFICO 75

$\begin{array}{lll}\text { 5. CONCLUSÕES } & 108\end{array}$ 


\section{INTRODUÇÃO}

O cuidado com a saúde dos animais de companhia tem crescido nos últimos anos. Para muitos proprietários, o cão deixou de ser apenas um simples animal de estimação e passou a ser um membro da família. Hoje em dia, a conduta rápida no tratamento de alterações clínicas e a aplicação de terapêutica adequada tornam-se imprescindíveis na clínica veterinária de pequenos animais. Assim, torna-se necessário que o clínico veterinário tenha conhecimento das alterações que mais acometem determinados ógãos, incluindo as alterações que afetam as mãos e os pés.

As lesões neoplásicas e não neoplásicas que afetam os dígitos de animais de companhia geralmente possuem manifestação clínica semelhante (MARINO et al., 1995) e, muitas vezes, podem resultar em amputação da região afetada (WOBESER et al., 2007). As manifestações clínicas mais comuns são massa visível e/ou claudicação, e é frequente existir ulceração dessa massa e alterações da unha (MADRUGA, 2011). Além disso, devido ao fato de frequentemente ocorrer infecção secundária, neoplasmas digitais podem inicialmente ser mal diagnosticados como paroníquia crônica ou osteomielite (WOBESER et al., 2007; MADRUGA, 2011).

Embora alguns estudos detalhem a prevalência e a caracterização clínico-patológica de alterações digitais em cães em alguns países (BELLUCO et al., 2013; HENRY et al. 2005, KIM et al. 2016; MADRUGA, 2011; MARINO et al., 1995), trabalhos similares não tem sido realizados no Brasil. Em um estudo norte-americano, foi observada prevalência alta de neoplasmas digitais em cães de grande porte (64\%), comparado com cães de médio porte (33\%) e de pequeno porte (12\%), além de afetar predominantemente machos (62\%). Além disso, $61 \%$ dos casos correspondiam a neoplasias malignas, $20 \%$ neoplasias benignas e $19 \%$ 
se tratavam de inflamações piogranulomatosas (MARINO et al., 1995). Alguns trabalhos têm apontado o carcinoma de células escamosas como a neoplasia mais frequentemente diagnosticada em dígitos de cães (HENRY et al., 2005; KIM et al., 2016; MARINO et al., 1995; WOBESER et al. 2007).

Devido às manifestações clínicas das lesões digitais em cães serem semelhantes independentemente da causa, a histopatologia é comumente utilizada para determinar o estado de doença e o prognóstico (WOBESER et al. 2007). A amputação do dígito afetado é o tratamento mais frequente na rotina médica veterinário e o exame histopatológico é fundamental para o diagnóstico e classificação da neoplasia (HENRY et al., 2005; WOBESER et al., 2007).

Portanto, a avaliação anatomopatológica desempenha papel fundamental na pesquisa de características histológicas que, associadas às informações provenientes do exame clínico sistemático, poderão fornecer dados essenciais para o estadiamento das neoplasias, o estabelecimento do prognóstico e da terapêutica (ARAÚJO, 2011). As características histológicas associadas às imuno-histoquímicas permitem prever o comportamento biológico das neoplasias, constituindo importantes fatores prognósticos e fonte de informação para o clínico que pretende instituir terapêutica eficaz (ARAÚJO, 2011).

\subsection{OBJETIVO}

Descrever as características clínico-patológicas e determinar a prevalência de 105 casos de alterações tumoriformes das mãos e pés de cães diagnosticados em três laboratórios de diagnóstico veterinário. 


\section{REFERENCIAL TEÓRICO}

\subsection{ANATOMIA BÁSICA DAS MÃOS E DOS PÉS}

O esqueleto da mão e do pé forma a base óssea das extremidades dos membros torácico e pélvico, respectivamente. Na mão o esqueleto abrange, em direção distal, os ossos do carpo, metacarpo e falanges; no pé é composto, do sentido proximal para distal, dos ossos do tarso, metatarso e digitais do pé (KÖNIG e LIEBICH, 2002).

\subsubsection{Anatomia básica das mãos}

Os ossos do carpo posicionam-se, nos animais domésticos, em uma fileira proximal (ou antebraquial) e em uma fileira distal (ou metacarpal), as quais cada uma são fundamentalmente formada por quatro ossos. A fileira proximal articula-se na extremidade proximal, na articulação antebraquiocárpica com o rádio e ulna, e a linha metacarpal distal articula-se na articulação carpometacárpica com os ossos metacárpicos (KÖNIG e LIEBICH, 2002).

Fundamentalmente, nos carnívoros, podem ser diferenciados na fileira antebraquial, no sentido medial para lateral, os ossos carporradial intermédio, carpoulnar e carpo acessório. Na fileira metacarpal, no sentido medial para lateral, em ossos cárpicos primeiro (I), segundo (II), terceiro (III) e quarto (IV). Nos carnívoros, o osso carporradial se funde com o osso carpo intermédio, aproximadamente depois do terceiro ou quarto mês pós-natal, formando o osso carpo intermedioradial (KÖNIG e LIEBICH, 2002; I.C.V.G.A.N, 2012). O osso acessório do carpo provavelmente apresenta origem sesamóide (DYCE et al., 2010).

Em cães e gatos, os ligamentos colaterais não se estendem além do comprimento do carpo e estão limitados a articulação proximal. Os ligamentos cárpicos curtos incluem alguns que são verticais, entre as articulações principais, alguns que são horizontais, unindo ossos 
vizinhos na mesma fileira, e outros que conectam o osso acessório do carpo à ulna, osso ulnar do carpo e quarto osso cárpico, e ao quarto e quinto ossos metacárpicos. Apenas as duas cavidades articulares distais se comunicam (DYCE et al., 2010).

Em relação ao metacarpo, cinco ossos podem ser diferenciados, no sentido medial para lateral, como metacárpico primeiro até o metacárpico quinto. Nos cães o primeiro osso metacárpico existe como um resquício digital, e o terceiro e o quarto são mais fortes e longos que os demais (KÖNIG e LIEBICH, 2002). Contudo, o primeiro metacarpo é o menor, o terceiro e o quarto são os mais longos e, aproximadamente, um quinto mais longo do que o segundo e o quinto ossos (GETTY et al., 1986).

$\mathrm{Na}$ região digital, as falanges distais da mão compreendem fundamentalmente cinco dígitos, indo do sentido medial (primeiro dedo) para lateral (quinto dedo). As falanges na mão podem ser divididas em proximal, média e distal (KÖNIG e LIEBICH, 2002). A falange proximal é um curto osso cilíndrico, cuja extremidade proximal está adaptada a cabeça do metacarpo; a falange média é mais curta do que a proximal, mas basicamente muito similar; e a falange distal possui forma da unha (DYCE et al., 2010). A falange distal é dividida em uma região em forma de cone, chamada processo ungueal, que é circundado por um fino colar ósseo, a crista ungueal (PATEL e FORSYTHE, 2010).

O esqueleto digital é completado pelos pares de ossos sesamóides proximais na face palmar da articulação metacarpofalangiana e por um osso sesamóide distal (cartilagem, em cães) na face palmar da articulação interfalangeana distal. Em cães, existem também pequenos ossos sesamóides no interior dos tendões extensores sobre a face dorsal das articulações metacarpofalangianas. Os ossos sesamóides na face palmar das articulações metacarpofalangianas estão incorporados no coxim metacárpico e associados a um complexo de ligamentos (DYCE et al., 2010). 
Os músculos de atuação primária nas articulações cárpicas e digitais são os músculos extensores do carpo e dos dígitos (extensor radial do carpo, ulnar lateral, extensor oblíquo do carpo, extensor digital comum e extensor digital lateral), músculos flexores do carpo e dos dígitos (flexor radial do carpo, flexor ulnar do carpo, flexor digital superficial e flexor digital profundo) e músculos digitais curtos (músculos interósseos) (DYCE et al., 2010).

Em relação aos tendões, distal aos ossos sesamóides proximais, os ramos do tendão flexor digital superficial são separados para a passagem do tendão flexor digital profundo e, nas articulações metacarpofalangianas e interfalangianas proximal e distal, são contidos por ligamentos anulares (DYCE et al., 2010).

Em relação aos nervos que inervam a região das mãos dos cães, as inervações cutâneas são realizadas pelo nervo ulnar, nervo radial e nervo mediano. Esse último inerva a maioria dos flexores do carpo e dígitos, o nervo ulnar inerva o restante dos flexores do carpo e digitais e, por último, o nervo radial supre os extensores das articulações do cotovelo, do carpo e dos dígitos (DYCE et al., 2010). A inervação sensorial do primeiro dedo ocorre somente pelo nervo radial, enquanto este, no segundo até o quinto dedo, supre apenas a superfície dorsal. As faces palmares do segundo até o quinto dedo (incluindo seus coxins) são inervados por ramos do nervo ulnar e nervo mediano (BRAGULLA et al., 2002).

A irrigação sanguínea da face dorsal da mão é feita por ramos da artéria ulnar, da artéria antebraquial superficial cranial, artéria radial e artéria interóssea caudal. Já na face palmar, a irrigação é feita pela artéria mediana, sendo que o primeiro e o segundo dedos são irrigadas pela artéria radial (GETTY et al., 1986).

\subsubsection{Anatomia básica dos pés}

Os ossos do tarso dispõem-se em fileiras: uma proximal, uma média e uma distal. Diferenciam-se na linha proximal e, em sentido medial para lateral, os ossos tarsotibial (talo) e tarsofibular (calcâneo); na linha intertarsal, encontra-se medialmente o osso central do tarso; 
e na linha distal contém, no sentido medial para lateral, os ossos tarsais primeiro, segundo, terceiro e quarto (KÖNIG e LIEBICH, 2002). Segundo a atual nomenclatura estabelecida pela International committee on veterinary gross anatomical nomenclature (I.C.V.G.A.N.) (2012), os atuais nomes são talo, calcâneo, tarso central, osso tarsal I, osso tarsal II, osso tarsal III e osso tarsal IV.

O esqueleto dos ossos do metacarpo do membro torácico corresponde aos ossos do metatarso do membro pélvico. Os ossos do metatarso, em comparação com os do metacarpo, são mais delgados e longos (KÖNIG e LIEBICH, 2002). Além disso, em cães o primeiro metatársico é rudimentar, visto que poucas raças apresentam, de forma consistente, um dígito vestigial do membro pélvico (DYCE et al., 2010). Em relação aos ossos digitais, a falange proximal, média e distal dos membros torácicos ou pélvicos comportam-se de modo idêntico, assim como os sesamóides (KÖNIG e LIEBICH, 2002).

Dentre os músculos de atuação primária nas articulações do tarso e dos dígitos, há os músculos cranilaterais da perna (tibial cranial, fibular longo, fibular curto, músculo extensor digital longo, extensor digital lateral e extensor longo do dedo I) e músculos caudais da perna (gastrocnêmico, flexor digital superficial e três músculos flexores digitais profundos) (DYCE et al., 2010; I.C.V.G.A.N., 2012).

A região do tarso até os dígitos é inervada pelos nervos safeno, isquiático, fibular e tibial. O nervo isquiático e seus ramos fibular e tibial suprem, em conjunto, a pele de todo o membro distalmente ao joelho, com exceção de uma faixa medial que é inervada pelo safeno (DYCE et al., 2010). Na face dorsal, o primeiro e o segundo dedos são inervados por ramificações do nervo fibular profundo, e do terceiro ao quinto dedo são por ramificações do nervo fibular superficial (GETTY et al., 1986), ao passo que as superfícies plantares (incluindo os coxins digitais) são supridas pelo nervo tibial (BRAGULLA et al., 2002). 
No pé, a irrigação sanguínea da face dorsal é realizada pelas artérias tibial cranial e safena, e a face plantar é realizada exclusivamente pela artéria safena (GETTY et al., 1986).

\subsubsection{Coxim}

O cão apresenta coxins digitais, metacárpico e cárpico no membro torácico, e coxins metatársico e digitais no membro pélvico (DYCE et al., 1997). No cão, apenas os coxins digitais e metacárpico (metatársicos) entram em contato com o solo, no qual as pequenas papilas que normalmente conferem aspereza à sua superfície podem tornar-se lisas e desgastadas em cães que caminham regularmente sobre pisos pavimentados. O coxim cárpico, logo distal ao osso acessório do carpo, normalmente não entra em contato com o solo, exceto nos animais que participam de competições de velocidade (DYCE et al., 2010). Os coxins digitais centralizam-se sobre as superfícies flexoras das articulações interfalângicas distais (DYCE et al., 1997).

\subsubsection{Unha}

A unha é uma estrutura queratinizada especializada da pele que utiliza como suporte a terceira falange (distal) (PATEL e FORYSTHE, 2010). Há autores que preferem relatar a unha em cães como garras, por serem animais com coxins sempre presentes (BRAGULLA et al., 2002).

De forma geral, o órgão digital dos carnívoros compõe-se do coxim digital e da unha, que a ele adere apicalmente. Correspondendo ao número de dedos, o cão possui em cada membro torácico ou pélvico quatro ou cinco unhas. A unha do primeiro dedo torácico é designada também por unha do polegar, a qual não toca o chão e não tem função. No cão doméstico é formada uma primeira unha predominantemente dérmica e sem base óssea, designada por unha de lobo, e muitas vezes é removida no filhote. Em algumas raças de cão ela é requisito para o padrão da raça, podendo até ser dupla (BRAGULLA et al., 2002). 


\subsubsection{Demais informações de relevância anatômica}

A drenagem linfática das extremidades dos membros torácicos dirige-se para os linfonodos cervicais superficiais e, nos membros pélvicos, para o linfonodo poplíteo (BRAGULLA et al., 2002).

\subsection{HISTOLOGIA BÁSICA DA PATA}

\subsubsection{Pele}

A pele é considerada o maior órgão do corpo e reveste-o externamente. É constituída por epiderme, derme, hipoderme e seus anexos (folículos pilosos e glândulas sebáceas, sudoríparas e outras). A pele com cobertura pilosa (hirsuta) é mais espessa nas regiões dorsal do corpo e lateral dos membros, e mais fina nas regiões ventral do corpo e medial dos membros pélvicos. Além disso, a pele hirsuta tem epiderme mais fina, ao passo que a pele sem pelos (glabra) do coxim possui epiderme mais espessa (HARGIS e GINN, 2013). A derme repousa sobre uma camada subjacente de tecido conjuntivo, a hipoderme (subcutâneo ou panículo) (BRUDAS et al., 2007). O tecido subcutâneo, constituído por lóbulos de tecido adiposo e fáscia, conecta as camadas mais superficiais (epiderme e derme) à fáscia e à musculatura adjacente (HARGIS e GINN, 2013).

\subsubsection{Epiderme}

A camada mais externa da pele, a epiderme, é constituída por epitélio pavimentoso estratificado queratinizado (BANKS, 1991). A epiderme é composta predominantemente de queratinócitos (cerca de $85 \%$ das células) e menor número de melanócitos (perto de 5\%), células de Langerhans (3 a 8\%) e células de Merkel (2\%) (CONCEIÇÃO e LOURES, 2016).

A epiderme é dividida em camadas, de acordo com a morfologia do queratinócito, o principal tipo celular da epiderme. A epiderme da pele hirsuta é constituída por quatro camadas básicas (estratos córneo, granuloso, espinhoso e basal), e a epiderme da pele glabra consiste em cinco camadas; a quinta camada adicional é o estrato lúcido, que está localizado 
entre o granuloso e o córneo (HARGIS e GINN, 2013). A espessura relativa desses estratos varia de região para região (BANKS, 1991).

Os queratinócitos posicionam-se no estrato basal da membrana basal, multiplicam-se por divisão mitótica e projetam-se para a superfície. Nesse sentido, as células percorrem os vários estágios do processo de diferenciação de queratinização e de cornificação, cujo produto final é a célula queratinizada morta. O processo contínuo de nova formação, queratinização, cornificação e, finalmente, descamação de células córneas é regulado por um mecanismo de feedback (BRAGULLA et al., 2002).

A camada mais ventral da epiderme é denominada estrato basal (BANKS, 1991). Essa camada única é constituída de células cuboides a colunares que repousa sobre uma membrana basal adjacente a derme, e essas células dão origem ao estrato espinhoso, uma camada de espessura variável, cujas células poligonais tornam-se escamosas em direção à superfície (BACHA e BACHA, 2003). O estrato espinhoso varia em espessura, sendo espesso em regiões sem pelos e fino em regiões com muitos pelos (BANKS, 1991). O estrato granuloso é assim chamado por causa dos grânulos querato-hialinos presente nas células (BRUDAS et al., 2007), sendo que o termo camada intermediária pode ser aplicado a esta zona (BANKS, 1991). O estrato lúcido é uma camada fina, pálida, eosinofílica e translúcida, estando limitada a regiões onde a epiderme é muito espessa, tais como os coxins podais dos carnívoros. Por fim, a camada cutânea mais superficial, o estrato córneo, é composta de células escamosas queratinizadas mortas, que se descolam a partir da superfície (BACHA e BACHA, 2003).

De forma geral, o estrato córneo é mais espesso na pele mais glabra (CONCEIÇÃO e LOURES, 2016). O revestimento superficial do tegumento, a queratina, é o produto da transformação da diferenciação das células basais, no qual as células que sofrem a queratinização se tornam células achatadas e anucleadas preenchidas por um produto de secreção - a queratina (BANKS, 1991). A queratina é dividida em queratina mole, presente 
na pele, e dura, constituinte de pelo, casco e unha (CONCEIÇÃO e LOURES, 2016). Ressalta-se que em estruturas compostas de queratina dura (em vez de mole), tais como cascos e garras, ambos os estratos granuloso e lúcido encontram-se ausentes (BACHA e BACHA, 2003).

Além das células epidérmicas, existem melanócitos, células de Langerhans e células de Merkel, especialmente no estrato germinativo (BRUDAS et al., 2007). Os melanócitos também estão presentes nas camadas mais inferiores do estrato espinhoso e produzem o pigmento melanina, conferindo coloração à pele e ao pelo (HARGIS e GINN, 2013). Além da camada basal da epiderme, os melanócitos estão presentes na bainha externa e nas células matriciais dos folículos pilosos, além dos ductos das glândulas sebáceas e sudoríparas (CONCEIÇÃO e LOURES, 2016). As células de Langerhans derivam da medula óssea, da linhagem monocítica-macrofágica, no qual processam e apresentam antígenos aos linfócitos T sensibilizados, modulando, assim, as respostas imunológicas da pele. As células de Langerhans estão presentes na camada basal, espinhosa e granular da epiderme, mas apresentam preferência pela posição suprabasal. Já as células de Merkel estão localizadas na camada basal e se ligam aos queratinócitos via junções desmossomais. As células de Merkel estão presentes na pele hirsuta e glabra, particularmente nas regiões do corpo com alta sensibilidade tátil (dedos e lábios) e na porção externa dos folículos pilosos (HARGIS e GINN, 2013). Elas têm a função de receptores de contato, os quais transmite a informação de um estímulo de contato para as fibras nervosas aferentes (BRAGULLA et al., 2002).

A epiderme e derme estão separadas por uma membrana basal típica (BANKS, 1991). Nas áreas livres de pelo, como os coxins, essa junção é irregular por causa das projeções epidérmicas que se interdigitam com as papilas dérmicas (rede de sulcos ou rede de pregas). Esse tipo de junção reforça a ligação entre a epiderme e a derme, proporcionando resistência a rasgos. Nas áreas densamente recobertas por pelos, a junção é mais suave e tem aparência 
ondulada, uma vez que a ligação entre a epiderme e a derme está reforçada pelos folículos pilosos (HARGIS e GINN, 2013).

\subsubsection{Derme}

A derme, ou cório, é constituída de fibras colágenas, elásticas e substância fundamental amorfa (formada por glicosaminoglicanos), e sustenta folículos pilosos, glândulas, vasos e nervos. Por convenção, a derme geralmente é subdividida em camadas superficial e profunda, que se misturam sem uma clara linha de demarcação (HARGIS e GINN, 2013). Alguns autores nomeiam a derme superficial como zona papilar e a derme profunda como zona reticular (BANKS, 1991; BRUDAS et al., 2007).

A derme superficial se adapta ao contorno da epiderme, e geralmente, sustenta a porção superior do folículo piloso e das glândulas sebáceas, e é composta por fibras delgadas de colágeno. Já a derme profunda sustenta a porção inferior do folículo piloso e das glândulas apócrinas e é composta por feixes colágenos maiores dos que os encontrados na derme superficial (HARGIS e GINN, 2013).

As papilas dérmicas são projeções digitiformes que se estendem para o interior da epiderme a partir da derme, e as papilas epidérmicas correspondentes também são evidenciadas como configurações complementares da epiderme e, em conjunto, estas formam as pregas epidérmicas. Além disso, a pele com muitos pelos geralmente não tem papilas (BANKS, 1991).

\subsubsection{Pelo e folículo piloso}

Os pelos são componentes específicos da pele dos mamíferos. Poucas são as regiões que não os apresentam, como, por exemplo, os coxins (BRAGULLA et al, 2002). Os pelos servem para numerosas funções, incluindo proteção, isolamento térmico, comunicação social e percepção sensorial (MAULDIN e PETERS-KENNEDY, 2016). Ressalta-se que a pele dos 
cães pelados naturalmente não é, de fato, sem pelos, mas recoberta por um grande número de pelos atrofiados (BRAGULLA et al., 2002).

Em uma análise longitudinal, o folículo piloso pode ser subdividido em: região infundibular (ou região pilossebácea), segmento entre a desembocadura do ducto sebáceo e o óstio folicular; istmo folicular (ou porção média), a porção entre o ducto sebáceo e a inserção do músculo eretor do pelo; e segmento inferior, entre a inserção do músculo eretor do pelo até a base do folículo piloso, a papila folicular. Além disso, o folículo piloso tem cinco componentes principais: a papila dérmica folicular, a matriz folicular, a haste pilosa, a bainha interna da raiz folicular e a bainha externa da raiz folicular (CONCEIÇÃO e LOURES, 2016).

No folículo piloso, a membrana basal separa o tecido conjuntivo do epitélio folicular, e a bainha externa da raiz é contínua com os estratos basal, espinhoso e granuloso (BANKS, 1991). A bainha interna da raiz é constituída por três camadas concêntricas, denominadas, da parte mais interna para a mais externa, como cutícula da bainha da raiz (única fileira de células achatadas), camada de Huxley (uma a três fileiras de células nucleadas) e camada de Henle (uma única fileira de células anucleadas). Essas camadas contêm grânulos citoplasmáticos eosinofílicos denominados grânulos trico-hialinos (CONCEIÇÃO e LOURES, 2016). Todas estas regiões não se estendem além da abertura das glândulas sebáceas no folículo (BANKS, 1991).

A cutícula ou bainha da raiz é uma monocamada de células queratinizadas que se apoia sobre a cutícula do pelo (BANKS, 1991). A raiz do pelo e bulbo piloso está em uma bainha epitelial dividida. A parte externa da bainha é contínua com a epiderme superficial. Contudo, as bainhas epidérmicas e dérmicas profundas, juntamente com o bulbo do pelo constituem o folículo piloso (BRUDAS et al., 2007).

As células germinativas da matriz, além de formar novas células pilosas, também dão origem à bainha radicular interna do folículo, sendo compostas por células parecidas com as 
da cutícula pilosa. A bainha radicular interna torna-se queratinizada e se afila distalmente, terminando proximamente à abertura das glândulas sebáceas no interior do folículo. A bainha radicular externa periférica representa uma continuação descendente da epiderme. Uma bainha de tecido conjuntivo (dérmica) circunda o folículo e toca a membrana basal da bainha radicular externa. Esta se funde com o resto do tecido conjuntivo dérmico (BACHA e BACHA, 2003).

Os pelos são estruturas cornificadas filiformes que são subdivididas em: eixo, que se projeta para além da superfície da pele; raiz, o qual é orientado obliquamente para dentro da derme e; bulbo piloso, presente na extremidade proximal com uma parte ampliada (BRUDAS et al., 2007). Os pelos surgem a partir das células germinativas (matriciais) do bulbo piloso, na base do folículo, e a multiplicação das células germinativas resulta em crescimento dos pelos (BACHA e BACHA, 2003). Além disso, a haste pilosa é subdividida em medula, córtex e cutícula (CONCEIÇÃO e LOURES, 2016). A cutícula é uma monocamada de células queratinizadas anucleadas que se interdigitam com a cutícula da bainha da raiz. O córtex, formado por várias camadas de células queratinizadas, forma a maior parte do pelo, e pode ser pigmentada. A medula pode estar ausente em alguns pelos, e quando presente é formado por células queratinizadas e cúbicas (BANKS, 1991). Dentro do pelo, a medula pode ficar reduzida distalmente, ficando completamente ausente em pelos lanosos. Contudo, a medida que as células pilosas são empurradas em direção à superfície a partir da região do bulbo piloso, tornam-se queratinizadas (BACHA e BACHA, 2003).

\subsubsection{Músculo eretor do pelo}

Fibras musculares lisas do músculo eretor do pelo ligam a bainha de tecido conjuntivo do folículo piloso à epiderme e são responsáveis por fazer o pelo ficar ereto (HARGIS e GINN, 2013). A sua contração não apenas ergue o pelo, mas também ajuda a espremer as glândulas sebáceas que estão localizadas entre a massa muscular e o folículo piloso (BANKS, 1991). 


\subsubsection{Glândulas}

As glândulas dérmicas incluem as sebáceas e as sudoríparas. As glândulas sebáceas, aberta para os folículos pilosos, estão presentes em alguns locais do organismo independente da presença de pelos (BRUDAS et al., 2007). As células basais (células-tronco) das glândulas sebáceas se dividem e dão origem a células secretoras vacuolizadas que sintetizam lipídeos. As células secretoras maduras mais internas morrem e se rompem, formando um produto oleoso chamado sebo, e essa forma de liberação é chamada de secreção holócrina (BANKS, 1991). Embora os ductos curtos das glândulas sebáceas drenem geralmente para o interior dos folículos piloso, elas também podem drenar diretamente sobre a superfície cutânea (BACHA e BACHA, 2003). As glândulas sebáceas são maiores e mais numerosas nas junções mucocutâneas e nas regiões interdigital, dorsal da cauda, mentoniana, cervicodorsal e lombossacra. Entretanto, as mesmas encontram-se ausentes nos coxins podais e no plano nasal de cães e gatos (CONCEIÇÃO e LOURES, 2016).

Já as glândulas sudoríparas são diferenciadas em dois tipos, as secretoras apócrinas e écrinas (BRAGULLA et al., 2002). Tradicionalmente, as glândulas merócrinas (écrinas) liberavam o produto da secreção através da exocitose e as apócrinas o produto secretório liberavam pequenos pedaços do citoplasma que continha o produto, sendo desprendidos da superfície livre da célula (BACHA e BACHA, 2003). Esta classificação foi baseada em uma suposta secreção apócrina das glândulas de odor; no entanto, esta classificação foi posteriormente refutada (BRUDAS et al., 2007). Contudo estudos recentes têm sugerido que as glândulas sudoríparas apócrinas e écrinas sejam denominadas de epitriquiais e atriquiais, respectivamente. Neste caso, as glândulas sudoríparas epitriquiais estão presentes em toda a pele hirsuta e ausentes no plano nasal e nos coxins podais, e as glândulas sudoríparas atriquiais (merócrinas) estão presentes apenas nos coxins podais (CONCEIÇÃO e LOURES, 2016). Anatomicamente, as glândulas sudoríparas podem ser desenroladas ou altamente 
enroladas e podem ser tubulares ou saculares. Elas drenam sua secreção através de um ducto, no interior de um folículo piloso ou por cima da superfície cutânea. Células mioepiteliais contráteis circundam as células secretoras e a porção inicial dos seus ductos (BACHA e BACHA, 2003). Entretanto, caso seja levado em conta as glândulas atriquiais, estas se abrem diretamente na superfície epidermal, ao contrário das glândulas epitriquiais, que se abrem no infundíbulo do folículo piloso (CONCEIÇÃO e LOURES, 2016).

\subsubsection{Hipoderme}

A hipoderme, ou subcútis, consiste em tecido conjuntivo frouxo que une a derme ao periósteo, ao pericôndrio ou à fáscia profunda subjacentes, permitindo a mobilidade tegumentar sobre as estruturas. Quando a hipoderme está infiltrada por numerosas células adiposas, esta camada é chamada panículo adiposo (BANKS, 1991). O tecido subcutâneo, ou panículo adiposo, é de origem mesenquimal, e é a mais profunda e espessa camada da pele (CONCEIÇÃO e LOURES, 2016).

\subsubsection{Demais estruturas da pele}

Na derme normal, há mastócitos, linfócitos, plasmócitos, macrófagos, e, raramente, eosinófilos e neutrófilos. Essas células são derivadas da medula óssea e transportadas a derme pelo sangue, e assim, elas ficam tipicamente concentradas ao redor dos pequenos vasos sanguíneos (HARGIS e GINN, 2013). Observam-se também os dendrócitos dérmicos, que se distribuem por toda a derme, mas localizam-se na região perivascular (CONCEIÇÃO e LOURES, 2016).

O suprimento e a drenagem sanguíneas da pele são feitos por artérias e veias do subcutâneo que, devido à mobilidade da pele, têm um curso tortuoso (BRUDAS et al., 2007). As artérias cutâneas dão origem a três plexos vasculares: o profundo, o médio e o superficial. O plexo profundo supre o tecido subcutâneo e as porções profundas de folículos e glândulas apócrinas; o plexo médio supre as glândulas sebáceas, a porção média dos folículos e os 
músculos eretores dos pelos; e o plexo superficial provê as porções superficiais dos folículos e a epiderme (HARGIS e GINN, 2013).

O fornecimento linfático ocorre por redes capilares linfáticas que começam subepidermalmente e investe os folículos pilosos e glândulas da pele (BRUDAS et al., 2007). Os capilares linfáticos surgem na epiderme superficial e se juntam ao plexo subcutâneo. Os vasos linfáticos convergem, então, para formar canais maiores que eventualmente se estendem até os linfonodos periféricos (HARGIS e GINN, 2013).

Em relação a anatomia cutânea sensorial, a pele tem a maior superfície sensorial do corpo, cuja função é exercida por termorreceptores (unidades frias e quentes), mecanorreceptores (corpúsculo de Pacini, corpúsculo de Meissner e corpúsculo de Ruffini) e nocirecptores (CONCEIÇÃO e LOURES, 2016). Além disso, os nervos da pele são uma mistura de fibras nervosas motoras e sensoriais. Contudo, a pele é um vasto e importante órgão sensorial, no qual as terminações nervosas ocorrem na hipoderme, derme e epiderme. Além disso, ramos de nervos cutâneos inervam os folículos pilosos formando uma rede folicular pilosa (BANKS, 1991).

\subsubsection{Particularidades do coxim}

Os coxins digitais dos carnívoros são regiões da pele altamente queratinizadas, espessadas, altamente pigmentadas e desprovidas de pelo (BANKS, 1991). A epiderme do coxim contem até $2 \mathrm{~mm}$ de espessura, formando depressões correspondentes (BRUDAS et al., 2007).

Os coxins digitais (palmares ou plantares) dos cães tem a epiderme composta de todas as camadas, incluindo o estrato lúcido (HARGIS e GINN, 2013). É nos coxins que o estrato espinhoso da epiderme se torna muito mais espesso (CONCEIÇÃO e LOURES, 2016). Notase que as papilas dérmicas, que aumentam a superfície de contato com a epiderme, são típicas das regiões submetidas à sobrecarga mecânica, como nos coxins plantares de carnívoros 
(BANKS, 1991). O subcutâneo do coxim é espesso, resistente e contém uma mistura de fibras colágenas e elásticas entremeadas por tecido adiposo (DYCE et al., 1997). Esta infiltração de tecido adiposo atua no amortecimento mecânico (BANKS, 1991). O subcutâneo do coxim canino contém glândulas sudoríparas, cujos ductos canalizam pela epiderme cornificada (DYCE et al., 1997), enquanto que as glândulas écrinas (atriquiais) estão presentes na derme e no tecido adiposo dos coxins (HARGIS e GINN, 2013). Além disso, bandas bem desenvolvidas de tecido conjuntivo estão presentes nos coxins do metacarpo e do metatarso, no qual fixam os coxins próximo ao metacarpo ou metatarso, respectivamente (BRUDAS et al., 2007).

Por fim, os coxins são ricamente supridos de vasos sanguíneos e linfáticos, bem como nervos (BRUDAS et al., 2007).

\subsubsection{Unha}

As unhas dos cães protegem a terceira falange e consistem histologicamente por parede (faces lateral e dorsal) e sola (face ventral), ambas formadas por epitélio estratificado escamoso queratinizado, onde a parede é constituída por queratina dura e a sola por queratina mais macia (HARGIS e GINN, 2013). Fundamentalmente se diferencia uma queratinização macia de uma queratinização dura, no qual a macia ocorre com a participação do estrato granuloso e a dura sem essa camada celular. Para a epiderme, a queratinização macia é típica, sendo a dura uma modificação característica encontrada na epiderme do órgão digital e da garra (BRAGULLA et al., 2002).

A derme da unha, conhecida como região ungueal, é constituída por colágeno denso, tecido elástico e vasos sanguíneos. E a dobra da unha cobre uma pequena parte da parede lateral e dorsal, próximo a sua inserção (HARGIS e GINN, 2013). 


\subsection{PRINCIPAIS ALTERAÇÕES DA REGIÃO DA MÃO E DO PÉ}

Há áreas da pele que em virtude de sua localização anatômica, por serem estruturas especializadas ou por sua função, merecem atenção especial quando se levam em considerações as doenças que afetam estes locais (PATEL e FORSYTHE, 2010). Dermatoses podais (pododermatoses) são doenças frequentemente encontradas na prática de pequenos animais, lembrando que há várias causas de doenças que envolvem as patas e que a determinação da etiologia da dermatose é a melhor estratégia para que o tratamento seja eficaz (WHITE, 1989).

Os dígitos podem ser alvo de alterações neoplásicas, benignas e malignas, e de alterações inflamatórias. Com base na literatura internacional, a neoplasia digital mais comum em cães é o carcinoma de células escamosas, seguindo-se do melanoma (HENRY et al., 2005; MADRUGA, 2011; MARINO et al., 1995; MEDLEAU e HNILICA, 2009; WOBESER et al., 2007). Contudo, além de CCE e melanoma, outras tumorações são relatadas, mas de forma aleatória e com raros estudos específicos da região. As alterações detalhadas a seguir foram todas as alterações observadas nos pés e nas mãos de cães deste estudo, mesmo que a alteração tenha sido encontrada uma única vez, adicionadas de algumas alterações de maior relevância de acordo com a literatura consultada.

\subsubsection{Alterações neoplásicas}

Um estudo que descreve a incidência dos diferentes tipos de neoplasias subungueais em cães, realizado nos Estados Unidos, verificou que, quando comparados a massas de outras regiões cutâneas, os tumores digitais são pouco frequentes, entretanto, 53,5\% dessas neoplasias são malignas. Além disso, múltiplos dígitos podem ser acometidos e metástases (525\% dos casos) podem ocorrer para linfonodos regionais e pulmão (HENRY et al., 2005). Entretanto, alguns autores citam que neoplasias primárias subungueais são comuns em cães, e 
aproximadamente um terço a metade dos casos de neoplasias ungueais primárias são carcinomas de células escamosas (VAIL e WITHROW, 2007).

A seguir serão descritas as alterações neoplásicas citadas como importantes na região das patas de cães.

\subsubsection{Neoplasmas epiteliais}

\subsection{Adenoma apócrino}

Adenomas de glândula apócrina são oriundos de células da glândula apócrina, sendo lesões incomuns em cães e que ocorrem mais em animais idosos (MEDLEAU e HNILICA, 2009). Os adenomas apócrinos simples são nódulos dérmicos bem circunscritos, firmes ou flutuantes, que em cães apresentem de 0,5 a 4 cm de diâmetro (GROSS et al., 2009). Macroscopicamente, o tumor localiza-se entre a derme e a hipoderme. Ao corte, alguns são multilobulados e císticos, estando os lóbulos cheios de líquido claro, e há múltiplos septos interlobulares conjuntivos (GOLDSCHMIDT e HENDRICK, 2002).

A cabeça, o pescoço e a região dorsal do tronco são as regiões anatômicas mais acometidas em cães (GROSS et al., 2009). Além disso, a incidência é maior entre oito a onze anos de idade (GOLDSCHMIDT e HENDRICK, 2002). Golden Retrievers, Cocker Spaniels e Pastores Alemães parecem ser mais predispostos (CONCEIÇÃO e LOURES, 2016).

Histologicamente, os adenomas apócrinos consistem de nódulos dérmicos bem delimitados que contém vários cistos, frequentemente revestidos por epitélio colunar proliferativo, com fluido claro ou eosinofílico, e com atividade mitótica baixa (MEDLEAU e HNILICA, 2009). Os adenomas apócrinos secretórios são divididos em simples e complexo (misto), no qual o misto se diferencia do simples por possuir proliferação de células mioepiteliais e diferenciação mixóide ou condroide (CONCEIÇÃO e LOURES, 2016; GROSS et al., 2009). 


\subsection{Adenoma sebáceo}

Os adenomas sebáceos são neoplasmas cutâneos de origem glandular e ductal, que se apresentam nas formas simples e composta, respectivamente, e podem ser solitários ou múltiplos (GROSS et al., 2009; JONES et al., 2000). O neoplasma ocorre comumente na pele de cães, especialmente em Cocker Spaniels e Poodles (THRALL, 2007). A faixa etária dos animais afetados varia em torno de 10 anos de idade, mas pode, ocasionalmente, ocorrer em indivíduos com menos de 1 ano de idade (GROSS et al., 2009).

Macroscopcamente, esses neoplasmas geralmente são firmes, proeminentes, com protuberância semelhante à verruga ou couve-flor, com diâmetro variando de poucos milímetros a vários centímetros (MEDLEAU e HNILICA, 2009). Apresentam coloração amarelo pálido a branco (GOLDSCHMIDT e HENDRICK, 2002), mas podem ser melanizados e assumir uma cor que varia entre marrom e preto. A pele sobrejacente normalmente possui alopecia e, às vezes, pode estar ulcerada (GROSS et al., 2009). Em cães este tumor apresenta predileção pela cabeça (GOLDSCHMIDT e HENDRICK, 2002; GROSS et al., 2009; MEDLEAU e HNILICA, 2009; THRALL, 2007;).

Na histologia este tumor mostra diferenciação sebácea, com predominância de sebócitos e poucas células de reserva basalóides e ductos, enquanto adenomas ductais sebáceos têm uma preponderância de ductos com menos sebócitos e células de reserva basaloides (GOLDSCHMIDT e HENDRICK, 2002). O adenoma sebáceo é histologicamente semelhante a hiperplasia sebácea, porém com maior quantidade de células germinativas basaloides e sebócitos imaturos, além de baixa atividade mitótica e perda da organização ao redor do ducto central (MEDLEAU e HNILICA, 2009). A hiperplasia nodular sebácea retém a orientação normal das glândulas ao redor dos ductos e do infundíbulo folicular, diferentemente do adenoma sebáceo (GROSS et al., 2009). 


\subsection{Carcinoma de células basais}

O carcinoma de células basais (CCB) é um tumor epitelial maligno de baixo grau que não mostra diferenciação epidérmica ou anexal (GOLDSCHMIDT e HENDRICK, 2002). São incomuns no cão (GOLDSCHMIDT e HENDRICK, 2002; GROSS et al., 2009), ocorrendo em cães entre 3 e 14 anos de idade, não havendo predileção racial, entretanto apresenta uma incidência maior em fêmeas (GOLDSCHMIDT e HENDRICK, 2002).

CCB geralmente ocorre solitário a ocasionalmente múltiplo, alopécico e com crosta, em placas ulceradas ou nódulos umbilicados que medem poucos milímetros a vários centímetros de diâmetro (GROSS et al., 2009; MAULDIN e PETERS-KENNEDY, 2016). A pele pode ter tonalidade azul ou preta por causa do pigmento melanina na neoplasia (MAULDIN e PETERS-KENNEDY, 2016). Segundo Goldschmidt e Hendrick (2002) a cabeça e o pescoço são frequentemente afetados, entretanto, segundo Gross et al. (2009) em cães o CCB apresenta predileção pelo tronco e ocasionalmente afeta a pele glabra.

Histologicamente, as células tumorais se assemelham a células basais normais da epiderme (GOLDSCHMIDT e HENDRICK, 2002). O principal parâmetro de malignidade é a invasão dos tecidos adjacentes com fibroplasia intensa do estroma (CONCEIÇÃO e LOURES, 2016). Alguns autores reconhecem três variantes histopatológicas do CCB em cães e gatos: sólido, queratinizante e de células claras (GROSS et al., 2009; MAULDIN e PETERS-KENNEDY, 2016). A variante de células claras tem sido observada exclusivamente em gatos (GROSS et al., 2009). Metástases para linfonodos ou locais distantes são possíveis, embora raramente documentadas (CONCEIÇÃO e LOURES, 2016).

\subsection{Carcinoma de células escamosas}

Carcinoma de células escamosas (CCE) é um neoplasma epitelial maligno, de crescimento lento e não necessariamente metastático, comum em cães (ROSOLEM et al., 2012). O CCE é uma neoplasia com origem nos queratinócitos que representa 
aproximadamente 5\% das neoplasias cutâneas em cães (MOURA, 2012) e é considerado o segundo tumor cutâneo mais comum em cães, após o mastocitoma (GROSS et al., 2009).

Existem vários fatores que estão associados com o desenvolvimento do CCE, incluindo a exposição prolongada à luz ultravioleta, a falta de pigmento em epiderme nos locais de desenvolvimento de tumores, e a falta ou escassez de pelo nos locais afetados (GOLDSCHMIDT e HENDRICK, 2002). A causa exógena mais comumente aceita é a exposição à luz ultravioleta, com consequente lesão do DNA e mutagenicidade associada (ROSOLEM et al., 2012). O desenvolvimento do CCE também tem sido associado com papiloma vírus, inclusive em cães (MAULDIN e PETERS-KENNEDY, 2016).

A maior incidência do CCE canino ocorre entre 6 e 10 anos de idade, sem predileção sexual, na região da cabeça, abdômen, membros torácicos, membros pélvicos, períneo e dígitos (GOLDSCHMIDT e HENDRICK, 2002). Macroscopicamente, o CCE se apresenta com placas crateriformes, papilares ou massas fungiformes que variam de poucos milímetros a alguns centímetros de diâmetros, além de que alopecia, crostas e úlceras estão presentes (GROSS et al., 2009). O CCE pode se manifestar tanto como lesão proliferativa como ulcerativa (VAIL e WITHROW, 2007).

O CCE é a alteração mais comum na região dos dígitos de cães (CONCEIÇÃO e LOURES, 2016; HENRY et al., 2005; KIM et al., 2016; MADRUGA, 2011; MARINO et al., 1995; MEDLEAU e HNILICA, 2009; VAIL e WITHROW, 2007; WOBESER et al., 2007). Um estudo concluiu que o CCE representa $47,4 \%$ de todas as lesões malignas digitais caninas (BELLUCO et al., 2013).

Em relação ao CCE especificamente na região das patas, Wobeser et al. (2007) e Madruga (2011) observaram maior prevalência em machos. A idade média dos cães encontram-se entre 9 e 11 anos (BELLUCO et al., 2013; HENRY et al., 2005; MADRUGA, 2011; WOBESER et al., 2007). Rottweiler e Schnauzer foram as duas raças mais comumente 
afetadas por CCE (KIM et al., 2016; WOBESER et al., 2007), vindo em seguida outras raças como Labrador Retriever e Poodle (MAULDIN e PETERS-KENNEDY, 2016; MEDLEAU e HNILICA, 2009).

Macroscopicamente, quando o dígito é atingido por CCE, este apresenta-se edemaciado e frequentemente dolorido ou pruriginoso. Paroníquia e dermatite erosiva ou ulcerativa são comuns, além de que pode haver deformação ou ausência de unha (MEDLEAU e HNILICA, 2009). Em geral, o CCE subungueal afeta um único dígito, o que leva a claudicação e deformidade da unha; entretanto, ocasionalmente, múltiplos dígitos podem estar afetados ou ser afetados em sequência em um período de anos (PATEL e FORYSTHE, 2010). Este fenômeno de múltiplos CCEs digitais tem sido descrito previamente em cães com pigmentação escura (HENRY et al., 2005; MAULDIN e PETERS-KENNEDY, 2016). Belluco et al. (2013) analisaram que 92\% dos cães com CCEs digitais tinham pelos escuros e $75,2 \%$ pertenciam a raças grande a gigantes.

Histologicamente o CCE subungueal consiste de proliferação não encapsulada, assimétrica e com margens irregulares e infiltrativas (PATEL e FORYSTHE, 2010). Nota-se também que as ilhas que se infiltram de epitélio escamoso neoplásico estendem-se através da lâmina basal do epitélio do leito ungueal com invasão e destruição do osso medular e cortical da terceira falange (GOLDSCHMIDT e HENDRICK, 2002). O CCE é classificado em três categorias: bem diferenciado, moderadamente diferenciado e pobremente diferenciado (GROSS et al., 2009), mas há outras classificações adicionais como acantolítico, verrucóide e alongado (GROSS et al., 2009; MAULDIN e PETERS-KENNEDY, 2016). Na maioria dos casos bem diferenciados, é observado a formação de "pérolas córneas", que correspondem a formação de lamelas concêntricas de queratina no centro de ninhos ou cordões de células neoplásicas (CONCEIÇÃO e LOURES, 2016). 
CCE subungueais em cães são localmente invasivos e quase sempre resultam em lise óssea da terceira falange (VAIL e WITHROW, 2007). Um estudo que comparou diagnóstico histológico de massa digitais com alterações de radiografias da região podal e do pulmão, observou que $13 \%$ dos animais com CCE digital apresentavam evidências radiográficas de metástase pulmonar até o tempo do diagnóstico e $80 \%$ dos cães com CCE tinham evidência de lise óssea na radiografia (MARINO et al., 1995).

Aparentemente, fatores epidemiológicos, grau histológico, índice mitótico e expressão de marcadores imuno-histoquímicos parecem não estar relacionados com a evolução clínica do CCE em cães com esta neoplasia na região digital (BELLUCO et al., 2013). Entretanto, o prognóstico varia de acordo com a localização e o estágio clínico no momento do diagnóstico, sendo considerado favorável quando o diagnóstico é realizado precocemente e também quando a excisão cirúrgica completa é possível, porém, quando houver lesões que envolvam estruturas ósseas, o prognóstico passa a ser reservado (ROSOLEM et al., 2012). De acordo com Medleau e Hnilica (2009) e Patel e Forysthe (2010) o dígito afetado pelo CCE deve ser amputado. Se houver suspeita de metástase localizada, deve-se realizar a retirada cirúrgica do linfonodo regional ou a amputação do membro (MEDLEAU e HNILICA, 2009).

\subsection{Carcinoma sebáceo}

O carcinoma (ou adenocarcinoma) sebáceo é a variante maligna de tumores de origem sebácea. É um tumor incomum em cães (GOLDSCHMIDT e HENDRICK, 2002; GROSS et al., 2009; THRALL, 2007; VAIL e WITHROW, 2007).

O adenocarcinoma sebáceo tende a se manifestar como nódulo intradérmico solitário eritematoso, alopécico ou ulcerado, com diâmetro inferior a quatro centímetros, que invade o subcutâneo (MEDLEAU e HNILICA, 2009). A idade média dos cães afetados por esse neoplasma varia entre nove e 13 anos, e as raças que apresentam maior risco são Cocker 
Spainel, West Highland White Terrier, Scottish Terrier e Husky Siberiano (GOLDSCHMIDT e HENDRICK, 2002).

Microscopicamente, observa-se lóbulos pouco definidos de células epiteliais grandes com graus variados de diferenciação sebácea e vacuolização citoplasmática, além de núcleos grandes e atividade mitótica moderadamente elevada (MEDLEAU E HNILICA, 2009). Em comparação aos adenomas, os adenocarcinomas sebáceos apresentam muitas das células tumorais indiferenciadas, e não possuem as óbvias gotículas de lipídeos no citoplasma; apenas algumas células apresentam citoplasma vacuolizado, semelhantes as células sebáceas normais (JONES et al., 2000).

Adenocarcinomas sebáceos geralmente se infiltram no local e metástases são raramente encontradas, mas quando elas ocorrem são para linfonodos regionais (GOLDSCHMIDT e HENDRICK, 2002; MEDLEAU e HNILICA, 2009).

\subsection{Epitelioma sebáceo}

Epiteliomas sebáceos são tumores frequentes em cães (GROSS et al., 2009). Apresentam diferenciação sebácea, baixo grau de malignidade e proliferação preponderante de células de reserva basaloides com poucos sebócitos e ductos proliferados (GOLDSCHMIDT e HENDRICK, 2002).

Os animais afetados são de meia-idade ou mais velhos, e a raça com mais predisposição ao desenvolvimento de tumores sebáceos é o Cocker Spaniel (GROSS et al., 2009). O epitelioma sebáceo geralmente é solitário e tende a ocorrer principalmente na cabeça e pálpebras (CONCEIÇÃO e LOURES, 2016).

Macroscopicamente, podem-se notar massas nodulares, firmes, espongiformes ou em formato de placa, que variam de vários milímetros a vários centímetros de diâmetro, e úlceras (GROSS et al., 2009). Alguns destes tumores podem ser marrons a pretos devido aos melanócitos associados ao tumor (GOLDSCHMIDT e HENDRICK, 2002). 
Na histologia o epitelioma sebáceo apresenta-se como lóbulos múltiplos compostos de células epiteliais basalóides entremeados por tecido colagenoso reativo e inflamação secundária. Observa-se também atividade mitótica relativamente alta e pode haver áreas escassas de diferenciação sebácea, metaplasia escamosa ou melanização (MEDLEAU e HNILICA, 2009). Ás vezes, para distinguir esta massa de um carcinoma de células basais, é necessário pesquisar células individuais que mostram evidência de diferenciação sebácea dentro do tumor (GOLDSCHMIDT e HENDRICK, 2002).

Os epiteliomas sebáceos podem ser localmente agressivos e recidivar profundamente após excisão cirúrgica (GROSS et al., 2009).

\subsection{Tricoepitelioma}

Tricoepiteliomas são neoplasmas comuns em cães que se originam de diferenciação rudimentar dos três segmentos do folículo piloso (infundíbulo, istmo e segmento inferior) (MAULDIN e PETERS-KENNEDY, 2016).

Tricoepiteliomas malignos são raros e descrito apenas em cães (GOLDSCHMIDT e HENDRICK, 2002; MAULDIN e PETERS-KENNEDY, 2016). Eles são geralmente maiores, assimétricos, e pobremente circunscritos em comparação com o seu homólogo benigno (MAULDIN e PETERS-KENNEDY, 2016) e, em muitos casos, os tumores se mostram ulcerados e em forma de placa (GROSS et al., 2009). Nenhuma predisposição de idade, sexo ou raça tem sido observada (GOLDSCHMIDT e HENDRICK, 2002). Entretanto, segundo Conceição e Loures (2016), cadelas castradas acima de 5 anos de idade tem maior risco de desenvolver tricoepitelioma, e algumas raças predispostas incluem Pastor Alemão, Golden Retriever, Basset Hound, Cocker Spaniel, Schnauzer Miniatura e Poodle. Localização dorsal no tronco parece ser a região anatômica mais afetada (GROSS et al., 2009).

Histologicamente, evidencia-se massa infiltrativa nodular envolvendo a derme e tecido subcutâneo. Muitas vezes as células tumorais estão associadas com a epiderme excedente ou 
infundíbulo folicular, e se estendem como cordões e ilhas de células basofílicas na derme (GOLDSCHMIDT e HENDRICK, 2002). Outras características incluem mitoses atípicas, necrose caseosa central dentro das ilhas de células matriciais, componente escamoso mínimo e invasão do tecido subcutâneo por vezes acompanhada de desmoplasia. A invasão linfática é considerada um achado essencial para confirmar malignidade por alguns patologistas (MAULDIN e PETERS-KENNEDY, 2016), e esta alteração pode ser vista na periferia do tumor (GOLDSCHMIDT e HENDRICK, 2002).

Tricoepiteliomas são distinguidos de todos os outros tumores epidérmicos, pois são rodeados por ninhos de células basais similares a folículos, e outros tumores ou cistos que se assemelham ao tricoepitelioma não apresentam esta característica (MAULDIN e PETERSKENNEDY, 2016).

\subsubsection{Neoplasmas mesenquimais}

Sarcomas de tecidos moles correspondem a uma população heterogênea de tumores mesenquimais com aparência patológica e comportamento clínico similares. Esses tumores são originários de tecidos mesenquimais, incluindo conjuntivo, muscular, adiposo cartilaginoso, ósseo e neurovascular (LIPTAK e FORREST, 2007).

Apesar das características histológicas diferentes, sarcomas de tecidos moles são agrupados por causa de algumas características importantes de comportamento biológico que são comuns a todos eles. Estas características foram descritos por Liptak e Forrest (2007) e incluem: 1) capacidade de surgir a partir de qualquer local anatômico no corpo, apesar de que pele e subcutâneo são os locais mais comuns; 2) tendem a aparecer como tecidos pseudoencapsulados com margens histológicas mal definidas; 3) tendência para se infiltrar através de planos faciais; 4) recorrência local comum após a excisão conservadora; 5) tendem a ter metástase hematógenas em mais de $20 \%$ dos casos; 6) metástase para o linfonodo regional é incomum (exceto para sarcoma de células sinoviais); e 7) má resposta à 
quimioterapia e radioterapia nos casos em que o tumor seja mensurável ou volumoso (com mais de $5 \mathrm{~cm}$ de diâmetro).

Sarcomas de tecidos moles tendem a ocorrer em cães de meia-idade a velhos, principalmente de raças médias a grandes. Estes muitas vezes apresentam uma massa firme e fixa envolvendo o tronco, extremidades ou a cavidade oral, geralmente de crescimento lento (EHRHART, 2005).

Com o desenvolvimento da imuno-histoquímica, a disponibilidade de anticorpos monoclonais e policlonais para vários marcadores de tecidos, e outras tecnologias específicas, melhoraram o diagnóstico de sarcomas de tecidos moles em patologia humana e veterinária.

\subsection{Hemangioma}

Hemangioma é um neoplasma benigno de células do endotélio vascular (CONCEIÇÃO e LOURES, 2016; MEDLEAU e HNILICA, 2009), que é mais comumente diagnosticado em cães do que sua versão maligna, o hemangiossarcoma (GROSS et al., 2009).

O hemangioma cutâneo geralmente ocorre em cães velhos (média de nove a dez anos) sem aparente predileção por sexo. O tumor pode ocorrer em qualquer local da pele, mas as regiões abdominal ventral e inguinal, além de locais levemente pigmentados ou com pouco pelo são mais predispostos. Danos solares crônicos nesta região têm sido sugeridos como uma das causas de hemangiomas cutâneos e estes podem ser múltiplos (MAULDIN e PETERSKENNEDY, 2016).

Em geral, o hemangioma na pele se manifesta como uma tumefação solitária, azulada a preto-avermelhada bem delimitada, redonda, firme a flutuante, com 0,5 a $4 \mathrm{~cm}$ de diâmetro, localizada na derme ou no tecido subcutâneo (MEDLEAU e HNILICA, 2009).

Na histologia é observado um nódulo bem delimitado na derme ou no tecido subcutâneo, composto de áreas preenchidas de sangue, revestidas por células endoteliais achatadas de aspecto relativamente normal, no qual não se constatam mitoses (MEDLEAU e HNILICA, 
2009). Os subtipos de hemangioma observado em cães e gatos incluem o cavernoso, o infiltrativo, o capilar, o arteriovenoso, o tipo tecido de granulação, o de células alongadas, o induzido pela luz solar e o angioceratoma (GROSS et al. 2009).

Os hemangiomas cutâneos geralmente apresentam crescimento lento e a excisão completa do tumor é curativa (GOLDSCHMIDT e HENDRICK, 2002).

\subsection{Hemangiossarcoma}

Hemangiossarcoma é um neoplasma maligno de células do endotélio vascular que pode atingir a pele, como sítio primário ou após metástases (MEDLEAU e HNILICA, 2009). O hemangiossarcoma pode ser único ou amplamente disseminado na apresentação (THAMM, 2007), embora mais comumente, observa-se a apresentação multicêntrica envolvendo o baço, fígado, pulmões e aurícula direita de cães, especialmente nas raças Pastor Alemão e Golden Retriever (GOLDSCHMIDT e HENDRICK, 2002). Um estudo que observou 62 casos de hemangiossarcoma em cães relatou maior ocorrência em indivíduos SRD (sem raça definida), com idade média de 9-10 anos e afetando a pele (ÁVILA et al., 2011). Já outro estudo que analisou 40 cães com hemangiossarcoma, foi observado que, independentemente do sitio anatômico inicial, os órgãos mais afetados foram baço, pulmão, fígado, peritônio, rim, encéfalo, pleura e coração (FLORES et al., 2012).

O envolvimento cutâneo pode ser solitário ou, raramente, parte do quadro multicêntrico, e alguns hemangiossarcomas dérmicos caninos parecem ser o resultado de radiação solar crônica. Raças de pelos curtos e pele clara, como Greyhound, Whippets e Pit bulls americanos estão em maior risco, e uma pequena porcentagem dos tumores caninos pode representar a transformação maligna de hemangiomas (GOLDSCHMIDT e HENDRICK, 2002). Em relação a localização na pele, a lesão atinge principalmente os membros e os troncos de cães (MEDLEAU e HNILICA, 2009). 
Macroscopicamente, a neoplasia pode ser semelhante ao hemangioma ou pode se apresentar como tumefação esponjosa vermelho-escura a preta, pouco delimitada, com até 10 cm de diâmetro, e comumente resultando em alopecia, sangramento e ulceração (MEDLEAU e HNILICA, 2009). Contudo, a maioria dos hemangiossarcomas dérmicos vistos em cães se manifesta na forma de placas pouco definidas, de coloração vermelha a azul-escuro, ou na forma de nódulos com menos de $2 \mathrm{~cm}$ de diâmetro; e os subcutâneos são massas esponjosas pobremente circunscritas que podem medir até $10 \mathrm{~cm}$ de diâmetro (GROSS et al., 2009). Independente do tecido afetado, o hemangiossarcoma apresenta tamanhos variados, coloração cinza pálido a vermelho escuro ou roxo, macio a gelatinoso, e geralmente contendo sangue ou áreas de necrose na superfície de corte. Ressalta-se que o hemangiossarcoma é um tumor extremamente friável, e complicações associadas à ruptura e hemorragia são frequentes (THAMM, 2007).

Histologicamente, há infiltração de células pleomórficas, atípicas, espiraladas, hipercromáticas, com tendência a formar canais vasculares na derme ou no tecido subcutâneo, com taxa mitótica variável (MEDLEAU e HNILICA, 2009). Um estudo que analisou os critérios microscópicos mais comumente avaliados na rotina do diagnóstico anatomopatológico desse neoplasma (grau de diferenciação, índice mitótico, padrão estromal, pleomorfismo celular, atipia, necrose, hemorragia e trombose), nenhum destes critérios demonstrou qualquer relação com o grau de agressividade (FLORES et al., 2012). Entretanto, clinicamente o hemangiossarcoma cutâneo comumente rescidiva após a excisão e tem potencial para invasão local generalizada e metástase; mas, em geral, verifica-se ser menos agressivo, com um curso clínico mais longo, e a sobrevivência prolongada quando comparado com hemangiossarcomas viscerais (MAULDIN e PETERS-KENNEDY, 2016).

A imuno-histoquímica pode ser necessária para identificar as células em tumores anaplásicos. As células endoteliais neoplásicas expressam vimentina, antígeno relacionado ao 
fator VIII (fator de von Willebrand) e CD31 (MAULDIN e PETERS-KENNEDY, 2016). Em um estudo sobre hemangiossarcoma em cães, a imuno-histoquímica utilizando anticorpo antifator VIII foi invariavelmente positiva e auxiliou inclusive no diagnóstico definitivo daqueles casos menos diferenciados (FLORES et al., 2012).

\subsection{Lipoma}

Lipoma é um neoplasma benigno de adipócitos, comum no tecido subcutâneo (ocasionalmente na derme) de cães de meia idade ou mais velhos, especialmente nas raças Dobermann, Labrador e Schnauzer miniatura (MEDLEAU e HNILICA, 2009). Cadelas e cães machos castrados apresentam predisposição a formação destes tumores, e alguns animais apresentam numerosos nódulos (GOLDSCHMIDT e HENDRICK, 2002).

Macroscopicamente se apresenta como uma tumefação subcutânea única ou múltipla, móvel, bem delimitada, em formato de domo ou multilobulada, macia ou firme, com 1 a 30 cm de diâmetro (MEDLEAU e HNILICA, 2009). Ao corte observa-se que este tumor é bem circunscrito, não encapsulado, branco a amarelado, indistinguível do tecido adiposo normal e, além disso, apresenta aspecto gorduroso e flutua na água ou na formalina (GOLDSCHMIDT e HENDRICK, 2002). Mais raramente, o tumor pode se manifestar como uma grande massa mole e pouco delimitada que se infiltra nos músculos, tendões e fáscias adjacentes (lipoma infiltrativo) (MEDLEAU e HNILICA, 2009), podendo causar dor, interferir na função dos membros e invadir a parede dos vasos (MAULDIN e PETERS-KENNEDY, 2016). As lesões frequentemente situam-se no tronco, região dos glúteos e membros proximais (GOLDSCHMIDT e HENDRICK, 2002).

Histologicamente, os lipomas bem diferenciados são indistinguíveis do tecido adiposo normal, com exceção de um limite comprimido e delicado do estroma que normalmente serve para delinear a margem entre tumor e tecido adiposo normal adjacente (MAULDIN e PETERS-KENNEDY, 2016). Segundo Gross et al. (2009), a ausência de grandes vasos e 
troncos nervosos auxilia a diferenciar o lipoma do tecido adiposo inalterado. Necrose, hemorragia, fibrose e inflamação moderada de macrófagos podem ocorrer resultado de traumas no lipoma (MAULDIN e PETERS-KENNEDY, 2016).

A maioria dos lipomas apresenta massas de crescimento lento e expansivas que são curativas após a excisão cirúrgica. Entretanto, lipomas infiltrativos, apesar de benignos, são mais difíceis de apresentar excisão completa e podem requerer múltiplas excisões (GOLDSCHMIDT e HENDRICK, 2002).

\subsection{Melanoma}

O melanoma (ou melanoma maligno) é um neoplasma maligno de melanócitos (CAMARGO et al., 2008; CONCEIÇÃO e LOURES, 2016; GOLDSCHMIDT e HENDRICK, 2002; GROSS et al., 2009; MEDLEAU e HNILICA, 2009), que pode ser pigmentado ou não (amelanótico), apresentar úlceras e tende a ser maior e a ter progressão mais rápida do que a sua versão benigna (MEDLEAU E HNILICA, 2009).

Este neoplasma afeta cães entre três e 15 anos de idade, com o pico de incidência entre nove e 13 anos, sem predileção por sexo (GOLDSCHMIDT e HENDRICK, 2002). Em um trabalho que observou neoplasias melanocíticas cutâneas em cães, os melanomas acometeram animais mais idosos, sem predisposição sexual, e as raças mais acometidas foram SRD, seguidas por Rottweiler, Pinscher, Cocker Spaniel e Airedale (CAMARGO et al., 2008).

O melanoma pode surgir em qualquer parte do corpo, porém em cães situam-se mais comumente na cabeça, no tronco e nos dígitos (MEDLEAU e HNILICA, 2009). Alguns estudos relatam o melanoma como a segunda neoplasia maligna mais comum na região digital de cães (HENRY et al., 2005; MADRUGA, 2011; MARINO et al., 1995; MEDLEAU e HNILICA, 2009; WOBESER et al., 2007). Existe uma variação do melanoma, o melanoma maligno subungueal, que afeta o leito ungueal. O tumor, que surge no epitélio do leito ungueal, pode não ser visível na avaliação externa, mas pode apresentar-se clinicamente com 
paroníquia, deformidade da unha, ou perda de unha e claudicação (GOLDSCHMIDT e HENDRICK, 2002). De acordo com Conceição e Loures (2016), o melanoma maligno ungueal corresponde a cerca de $8 \%$ dos melanomas malignos em cães. Geralmente há lise da terceira falange (CONCEIÇÃO e LOURES, 2016; GOLDSCHMIDT e HENDRICK, 2002).

Macroscopicamente, o melanoma possui entre 1 a $3 \mathrm{~cm}$ de diâmetro, usualmente é séssil, mas alguns podem ser polipóides ou ter formato de placa, e podem ser acinzentados, amarronzados ou pretos, dependendo da quantidade de melanina, da presença da atividade juncional e da hiperpigmentação da pele sobrejacente (GROSS et al., 2009). Em relação específica ao melanoma digital, este geralmente se manifesta com uma protuberância semelhante à verruga ou nódulo pedunculado solitário bem delimitado, na forma de domo, firme, marrom a preto, alopécico e com 0,5 a $10 \mathrm{~cm}$ de diâmetro (MEDLEAU e HNILICA, 2009).

Segundo Gross et al. (2009), a localização do tumor tem sido considerada importante em relação ao comportamento clínico da neoplasia; tumores melanocíticos da matriz ungueal, da junção mucocutânea e da mucosa oral geralmente são malignos, enquanto que as lesões de pele providas de pelo, incluindo os lábios e os dígitos, são provavelmente benignas. Um trabalho que analisou as alterações de dígitos de cães observou que dentre as neoplasias derivadas dos melanócitos, 58\% eram melanomas e 42\% melanocitomas (KIM et al., 2016). Conceição e Loures (2016) reforçam que os melanomas são mais comuns na cavidade oral do cão e em junções mucocutâneas, em particular lábios, além de afetar comumente escroto e dígitos.

Histologicamente, os melanócitos neoplásicos estão presentes como pequenos ninhos ou como células individuais dentro da porção basal da epiderme, podendo ser encontrados nas camadas superiores da epiderme, uma característica não visto nos melanocitomas, diferenciando também por apresentar mitoses e úlceras mais frequentes (GOLDSCHMIDT e 
HENDRICK, 2002). No cão, um índice mitótico de 3 ou superior por dez campos de maior aumento parece ser o indicador mais preciso de um prognóstico ruim (CONCEIÇÃO e LOURES, 2016; MAULDIN e PETERS-KENNEDY, 2016). Observa-se também que os melanomas podem ser fortemente pigmentados ou amelanóticos e formam padrões de feixes, folhas, ninhos e espirais (MAULDIN e PETERS-KENNEDY, 2016). Segundo Gross et al. (2009), histologicamente os tumores melanocíticos de cães incluem os melanomas com atividade juncional e os melanomas dérmicos, no qual os melanomas dérmicos são subclassificados em melanoma de células balonosas e melanoma de células alongadas. Já Conceição e Loures (2016) classificam de forma um pouco diferente, no qual as neoplasias melanocíticas cutâneas são classificadas como: juncional, quando a proliferação ocorre na junção dermoepidérmica; dérmica, quando a proliferação melanocítica ocorre na derme; e composta, quando há proliferação juncional e dérmica.

Estudos indicaram que o grau de pigmentação e o padrão histopatológico não estão correlacionados com o prognóstico (MAULDIN e PETERS-KENNEDY, 2016). Em geral, neoplasmas melanocíticos orais apresentam prognóstico pior do que neoplasmas cutâneos, e aqueles no lábio ou no dígito tem pior prognóstico que os cutâneos (SMEDLEY et al., 2011b). Além disso, metástases de melanoma geralmente ocorrem por via linfática para os linfonodos regionais e pulmões (GOLDSCHMIDT e HENDRICK, 2002). Em um estudo que realizou a comparação de diagnóstico de massa digitais com alterações de radiografias da região podal e do pulmão, $32 \%$ dos cães com melanomas digitais apresentavam evidencias radiográficas de metástase pulmonar até o tempo do diagnóstico e 5\% com melanoma tinham evidência de lise óssea na radiografia (MARINO et al., 1995).

Em casos de melanoma indiferenciado ou amelanótico a imuno-histoquímica é muito útil para o diagnóstico. A imuno-histoquímica para Melan-A, antígeno melanocítico PNL2, e 
proteínas relacionadas à tirosinase 1 e 2 (TRP-1 e TRP-2) são importantes para a confirmação desses tumores (SMEDLEY et al., 2011a; GELBERG, 2013). Um trabalho que analisou a marcação de 35 casos de melanoma amelanócito em cães observou que 86,6\% dos casos foram positivos para a vimentina, $70 \%$ para a proteína S-100 e 56,6\% para o Melan-A (ROLIM et al., 2012).

\subsection{Osteossarcoma}

Osteossarcoma é uma neoplasia maligna nos quais as células neoplásicas formam osso, osteóide ou ambos, compreendendo aproximadamente 80\% das neoplasias ósseas primárias em cães (CARLOS e WEISBRODE, 2013; THOMPSON e POOL, 2002).

Alguns autores citam que o osteossarcoma ocorre em cães com idade mediana a idosos (cerca de 7 anos) (CAVALCANTI, 2007; CRAIG et al., 2016; THOMPSON e POOL, 2002), entretanto este pode ocorrer tipicamente em cães mais novos (CARLOS e WEISBRODE, 2013). O tumor ocorre mais frequentemente em raças de cães grandes e gigantes, estando diversas vezes associada ao aumento da altura e do peso (CARLOS e WEISBRODE, 2013; CRAIG et al., 2016). Além disso, os osteossarcomas do esqueleto apendicular são mais descritos em machos (CRAIG et al., 2016). Um estudo que analisou osteossarcoma em cães observou maior frequência em cães machos, Rottweiler, com idade média de 7,4 anos (CAVALCANTI, 2007). Além disso, outros fatores predispõem os animais ao desenvolvimento de osteossarcoma, como raça (São Bernardo, Dogue Alemão, Boxer, Pastor Alemão e Setter Irlandês), idade (o risco aumenta a partir dos 5 anos de idade e diminui depois dos 9 anos de idade), fixação de fraturas com instrumentos metálicos e infartos ósseos (cães miniatura) (SERAKIDES, 2016).

Em geral, o osteossarcoma é um neoplasma de crescimento progressivo que leva a mortalidade rápida (CRAIG et al., 2016; THOMPSON e POOL, 2002). Este tumor surge mais comumente na metáfise, sendo mais comum no rádio distal, na tíbia distal e no úmero 
proximal (CARLOS e WEISBRODE, 2013), aparentando ter maior predileção por membros torácicos do que os pélvicos (CRAIG et al., 2016). O crescimento geralmente é rápido, invasivo, localmente agressivo e doloroso (CARLOS e WEISBRODE, 2013), portanto, clinicamente geralmente apresenta manifestações que refletem o local da lesão, que associado à aparência radiográfica, pode levar ao diagnóstico presuntivo de osteossarcoma (THOMPSON e POOL, 2002). Além disso, pela característica invasiva, o osteossarcoma causa obstrução da drenagem linfática, com edema secundário da área adjacente ao tumor (SERAKIDES, 2016). Nota-se também que a osteopatia hipertrófica é uma sequela relativamente comum em cães com metástases pulmonares de osteossarcoma ou com grandes tumores na costela que invadam a cavidade torácica (THOMPSON e POOL, 2002). Fraturas patológicas também são frequentes (SERAKIDES, 2016). Osteossarcomas digitais são mais comuns em gatos do que cães. Ocasionalmente, o tumor ocorre em locais de irritação e reparos crônicos, como aqueles associados a osteomielite, infartos ósseos ou dispositivos fixadores (CRAIG et al., 2016).

A aparência histológica do osteossarcoma varia marcadamente, mas a produção de osteoide e / ou tumor ósseo por osteoblastos malignos é um fator comum (CRAIG et al., 2016). Os osteossarcomas podem ser classificados como simples (osso sintetizado em uma matriz colagenosa), composto (osso e cartilagem presentes) ou pleomórficos (anaplásico, com apenas pequenas ilhas de osteoide presentes) (CARLOS e WEISBRODE, 2013). Além disso, várias são as subclassificações histológicas do osteossarcoma baseado no tipo e quantidade de matriz e as características das células: osteoblástico, condroblástico, fibroblástico, pouco diferenciado e telangiectásico (DERNELL et al., 2007), além do osteossarcoma rico em células gigantes (CRAIG et al., 2016; THOMPSON e POOL, 2002). Segundo Serakides (2016), existe ainda o osteossarcoma do tipo combinado, em que não há padrão predominante, ou seja, dois ou mais subtipos se organizam para dar origem a um único tumor. A 
classificação do osteossarcoma também pode ser baseada na aparência radiográfica (líticos, escleróticos ou mistos) ou no local de origem (centrais, justacorticais ou periosteais) (CARLOS e WEISBRODE, 2013).

A ocorrência de metástase pulmonar hematógena prematura é comum, exceto para aqueles oriundos do esqueleto axial e, em particular, na cabeça. As metástases também podem ser difusas, envolvendo tecidos moles, assim como outros ossos (CARLOS e WEISBRODE, 2013). A amputação do membro afetado é o tratamento local padrão para cães com osteossarcomas apendiculares (DERNELL et al., 2007).

Há casos em que a imuno-histoquímica é necessária para diferenciar de outras neoplasias. Em um trabalho que analisou imuno-histoquímica de osteossarcoma canino, $98,2 \%$ dos osteossarcomas tiveram reatividade para vimentina, e a imunorreatividade à osteocalcina ocorreu em células osteoblásticas, condroblásticas e fibroblásticas de $91 \%$ dos casos. Observou-se também que a proteína S-100 foi expressa em 79,7\% dos tumores, tendo ocorrido em todos os tumores condroblásticos, e uma proporção significativa de osteossarcomas reagiu positivamente aos anticorpos 1A4 e HHF35 (CAVALCANTI, 2007).

\subsection{Sarcoma histiocítico}

Sarcoma histiocítico é um tumor maligno originado de células dendríticas, melhor caracterizado em cães, com apresentação localizada ou disseminada (CRAIG et al., 2016). A forma disseminada envolve vários tecidos, pode representar um estágio posterior da forma localizada (CRAIG et al., 2016) e tem sido denominada histiocitose maligna (AFFOLTER e MOORE, 2002; GROSS et al., 2009; JACOBS et al., 2002).

O sarcoma histiocítico localizado ocorre com mais frequência em cães de meia-idade e o disseminado em cães de meia-idade a velhos (JACOBS et al., 2002). Em um trabalho que analisou esta alteração em cães, a idade média dos cães afetados variou de 2 a 13 anos, e a proporção entre fêmeas e machos foi de 1,2:1 (AFFOLTER e MOORE, 2002). 
O sarcoma histiocítico é o tumor que ocorre mais comumente nas articulações de cães (CRAIG et al., 2016; GROSS et al., 2009). As raças Bernese Mountain, Rottweiler, Bullmastiff, Golden Retriever, Labrador Retriever e Flat-Coated Retriever são predispostas, especialmente se tiverem um problema pré-existente na articulação, como a ruptura do ligamento cruzado cranial. Esta hipótese está associada à transformação maligna de células dendríticas dentro de uma membrana sinovial cronicamente inflamada (CRAIG et al., 2016). Em um estudo que analisou 39 cães com desordens proliferativas histocíticas, os locais de predileção foram o subcutâneo e tecidos subjacentes nas extremidades, mas ocorreram tumores em outros locais, incluindo o baço, pulmão, cérebro, cavidade nasal e medula óssea (AFFOLTER e MOORE, 2002). De acordo com Jacobs et al. (2002), tumores ocasionais podem ser encontrados no baço, fígado, parede gástrica e língua.

As lesões aparecem como massas solitárias de rápido crescimento em locais cutâneos e subcutâneos, geralmente na parte distal do membro ao lado de uma articulação (JACOBS et al., 2002). O sarcoma histiocítico é grosseiramente multilobulado, sendo um tumor infiltrativo que muitas vezes preenche a articulação e se estende até as adjacências de ossos e tecidos moles. O joelho é a articulação mais afetada, seguida pelo cotovelo, ombro e articulações coxofemoral, do carpo e do tarso (CRAIG et al., 2016). Os animais com tumores periarticulares apresentam claudicação, além de inchaço lento e progressivo da articulação em questão (GROSS et al., 2009).

Microscopicamente, as células neoplásicas são redondas, poligonais a fusiformes, com citoplasma eosinofílico abundante, com limites celulares distintos e o citoplasma contém, por vezes, vacúolos (CRAIG et al., 2016). Dois padrões principais são reconhecidos: um em que ocorre o predomínio de células redondas e outro no qual predominam as células alongadas. Esta neoplasia é pobremente demarcada, localmente invasiva e caracterizada por proliferação densa de células pleomórficas que destroem a arquitetura tecidular original (GROSS et al., 
2009). Ambos os sarcomas histiocíticos caninos, localizados e disseminados, analisados em um estudo eram compostos de populações de células tumorais pleomórficas (AFFOLTER e MOORE, 2002). Células multinucleadas e mitoses incomuns podem ser vistos (CRAIG et al., 2016; JACOBS et al., 2002), enquanto que infiltrados inflamatórios são geralmente mínimos (JACOBS et al., 2002). Portanto, a aparência histológica do tumor disseminado é indistinguível da variedade localizada, no qual não se sabe se as células em qualquer uma das formas reativas podem sofrer transformação maligna ou se as células do sarcoma histiocítico localizado podem adquirir características que permitem uma maior disseminação (JACOBS et al., 2002).

As células neoplásicas expressam marcadores de superfície de leucócitos característicos de células dendriticas, tais como CD1, CD11c e MHC II (CRAIG et al., 2016), além de expressarem reação a CD45 e CD18 (GROSS et al., 2009). Ressalta-se que, embora as células tumorais sejam negativas para CD3 e CD79a, existem muitas vezes numerosos linfócitos não neoplásicos, assim como a outras células inflamatórias, tais como eosinófilos, neutrófilos e plasmócitos em todo o tumor (CRAIG et al., 2016).

Os sarcomas histiocíticos geralmente causam metástase nos linfonodos de drenagem em estágios avançados da doença, mas metástases distantes podem ocorrer (GROSS et al., 2009). Locais comuns para metástases incluem linfonodos, pulmões, fígado e baço (CRAIG et al., 2016). Prognóstico favorável é observado após excisão cirúrgica das massas tumorais primárias, em especial quando a amputação da extremidade é realizada; entretanto, o prognóstico para o sarcoma histiocítico disseminado é desfavorável, uma vez que o diagnóstico normalmente é feito em estágios avançados da doença, quando a cirurgia não é mais uma boa opção de tratamento devido à distribuição generalizada das lesões em órgãos internos (GROSS et al., 2009). 


\subsection{Tumor de bainha de nervo periférico}

Tumores cutâneos de origem neural são incomuns em animais domésticos, mas é provavelmente sub-diagnosticada devido à sua semelhança histológica com outros tumores mais comuns da pele. Elas podem ser compostas por um ou mais elementos de um nervo, que são o axônio, as células de Schwann e fibroblastos perineurais. Consequentemente, esses tumores são histologicamente heterogêneos, e a histogénese é frequentemente incerta resultando em várias e confusas classificações e terminologias na literatura, tendo sido chamados neurofibromas / neurofibrossarcomas, neurilemomas, neurinomas e schwannomas / schwannomas malignos (MAULDIN e PETERS-KENNEDY, 2016). Esta distinção pode ocasionalmente ser feita por imuno-histoquímica com os marcadores S-100, GFAP e outros anticorpos neurais, no entanto, preconizou-se empregar o termo "tumores da bainha de nervos periféricos", porque a maioria dos diagnósticos são feitos sem estes exames complementares e porque os marcadores, quando eles são usados, não são específicos (GOLDSCHMIDT e HENDRICK, 2002). O nome de tumor de bainha do nervo periférico é um termo amplo que propõe a inclusão de todos os tumores resultantes de nervos periféricos; no entanto, a maioria dos tumores são compostos por células de Schwann, sendo o termo schwannoma apropriado para a maioria destes tumores (MAULDIN e PETERS-KENNEDY, 2016).

Este tumor é incomum no cão (GOLDSCHMIDT e HENDRICK, 2002; GROSS et al., 2009). Segundo Gross et al. (2009), existe a variante benigna e maligna deste tumor, e ambos se apresentam como massas cutâneas circunscritas e lobuladas de consistência variável, e geralmente medem cerca de 2 a $3 \mathrm{~cm}$ de diâmetro, podendo chegar a $5 \mathrm{~cm}$, sendo que a maioria se desenvolve no subcutâneo, podendo se expandir até a derme. Eles são geralmente brancos a acinzentados e, às vezes, apresentam protuberâncias na superfície de corte (GOLDSCHMIDT e HENDRICK, 2002). 
As lesões se localizam, com mais frequência, na região do tronco e na porção distal dos membros (GROSS et al., 2009). Um trabalho que analisou este tumor em cães demonstrou que $40 \%$ dos tumores estavam nos membros torácicos, 28,57\% nos membros pélvicos, e o restante se localizava no tronco, pescoço, cabeça e cauda; e, além disso, o Pastor Alemão e o Poodle foram as raças mais acometidas (BOOS, 2013).

Microscopicamente, schwannomas são mais comumente compostos por pequenas células fusiformes caracterizados por núcleo oval, fusiformes ou onduladas, cromatina fina, pequeno nucléolo imperceptível e citoplasma indistinto e pálido. As células fusiformes formam espirais, fascículos entrelaçados, e remanescentes do nervo em paliçadas, havendo diminuição da tendência para formar espirais e paliçadas em tumores malignos (MAULDIN e PETERSKENNEDY, 2016).

Projeções digitiformes delicadas de células tumorais comumente se estendem para tecidos adjacentes e entre planos fasciais, respondendo por recorrências frequentes (MAULDIN e PETERS-KENNEDY, 2016). Foi possível constatar em um trabalho que a chance de um animal que apresentava a variante maligna vir a desenvolver recidiva foi quatro a seis vezes maior em relação a um animal que apresentava o tumor benigno (BOOS, 2013).

Histologicamente e comportamentalmente, tumores da bainha de nervos periféricos podem ser difíceis de diferenciar de fibromas, fibrossarcomas bem diferenciados, e tumores da parede perivascular caninos. No entanto, os tumores neurais expressam a proteína S-100, proteína básica de mielina, enolase neurônio específica, e proteína ácida fibrilar glial, ao passo que os outros tumores cutâneos mais comuns não o fazem (MAULDIN e PETERSKENNEDY, 2016).

\subsection{Tumores da parede perivascular canina}

Tumores caninos da parede perivascular são neoplasias mesenquimais que foram anteriormente referidos como hemangiopericitomas, oriundas de células fusiformes 
relativamente comuns, histologicamente distintos de cães (MAULDIN e PETERSKENNEDY, 2016). A nomenclatura foi alterada para refletir a origem do tumor, isto é, as células neoplásicas são derivadas da parede vascular, e não do endotélio (AVALLONE et al., 2007; MAULDIN e PETERS-KENNEDY, 2016). O estudo realizado por Avallone et al. (2007), incluindo casos diagnosticados como hemangiopericitoma e selecionados com base em caraterísticas histológicas e citológicas específicas, demonstrou a origem perivascular da maioria dos tumores, excluindo o diagnóstico de tumores de bainha de nervo periférico e outros tipos de tumores de células fusiformes, de acordo com o fenótipo e a morfologia. Este estudo identificou padrões morfológicos consistentes com o diagnóstico de tumores da parede vascular, no qual este nome geral para esta categoria de neoplasia foi proposto. Além disso, uma subclassificação foi realizada através da aplicação de um amplo painel de anticorpos, identificando várias subcategorias deste tumor (AVALLONE et al., 2007). Contudo, esta categoria inclui os seguintes subtipos do tumor da parede perivascular: tumor glômico, hemangiopericitoma verdadeiro, angioleiomioma / sarcoma, angiomiofibroblastoma e angiofibroma (AVALLONE et al., 2007; MAULDIN e PETERS-KENNEDY, 2016). Apesar da nova nomeação, este tumor aparenta ser comum em cães idosos, com relato de maior ocorrência em animais de raças grandes (MAULDIN e PETERS-KENNEDY, 2016; MEDLEAU e HNILICA, 2009).

Em geral, esse neoplasma se manifesta como um tumor único, multinodular, bem delimitado, afetando a derme ou o tecido subcutâneo (GROSS et al., 2009; JONES et al., 2000; MAULDIN e PETERS-KENNEDY, 2016; MEDLEAU e HNILICA, 2009). Esses tumores podem ficar muito grandes, sendo difícil sua separação dos tecidos circunjacentes (JONES et al., 2000). A lesão pode ser hiperpigmentada, alopécica ou ulcerada e são encontradas mais comumente nos membros, no tórax e nos flancos (MEDLEAU e HNILICA, 2009). Santos (2005) analisou maior acometimento de membros (sobretudo a região de 
articulações) de cães com hemangiopericitoma. Todos os tumores caninos da parede perivascular têm comportamentos biológicos similares, e são infiltrativos, muitas vezes invadindo ao longo de planos fasciais. São comumente recorrentes e metástase é incomum (MAULDIN e PETERS-KENNEDY, 2016).

A característica microscópica dos tumores caninos de parede vascular inclui proliferação de células fusiformes tumefeitas, dispostas em camadas concêntricas espiraladas, às vezes com pequenos vasos no centro. Nas margens do tumor, microextensões "digitais" das células tumorais comumente se infiltram além dos planos faciais, e essa é a razão pela qual muitos tumores são incompletamente extirpados, apesar da impressão clínica de que eles são bem circunscritos (MAULDIN e PETERS-KENNEDY, 2016).

Por ser um tumor de difícil separação dos tecidos circunjacentes, eles demonstram tendência para recorrência local, devido a excisões incompletas (JONES et al., 2000). Esses neoplasmas por apresentarem esta taxa de recidiva local frequente se tornam mais invasivos após sucessivos procedimentos cirúrgicos (GROSS et al., 2009). Sobre um trabalho específico que analisou o prognóstico de tumores da parede perivascular em cães, os principais fatores relacionados ao prognóstico foram o tamanho do tumor, a profundidade e o perfil patológico da neoplasia (AVALLONE et al., 2014).

Um painel de anticorpos foi proposto para o diagnósico e aplicação correta dessa nova nomenclatura, incluindo vimentina, citoqueratina, fator VIII, CD31, GFAP, MBP, S100, melan-A e os marcadores musculares $\alpha$-SMA, pan actina, miosina e desmina. Visto que o tumor de parede perivascular canino abrange um grupo misto de entidades biológicas distintas, o diagnóstico deve ser considerado um processo de passos múltiplos em que a citologia, histologia e imuno-histoquímica podem ser necessárias, mas nem sempre é suficiente para diagnosticar e diferenciar estes tumores (AVALLONE et al., 2007). 


\subsubsection{Neoplasmas de células redondas}

Na região dos membros de cães, cita-se em primeiro lugar o mastocitoma, seguido do histiocitoma e do plasmocitoma.

\subsection{Histiocitoma}

Histiocitoma cutâneo é uma neoplasma benigno de células mononucleares oriundas de células de Langerhans epidérmicas, sendo comum em cães, com elevada prevalência em animais jovens com menos de quatro anos de idade (MEDLEAU e HNILICA, 2009). Segundo Patel e Forysthe (2010), há predileção racial, especialmente em Boxer, Dachshund, Terrier, Labrador, Cocker e Spaniel inglês. Um estudo que analisou histiocitoma cutâneo em cães, foi observado que Boxers e Dachshunds tiveram um risco significativamente maior do que todas as outras raças, e os cães de raça pura, em geral, tiveram um risco mais elevado que cães mestiços (TAYLOR et al., 1969).

Macroscopicamente, apresenta-se como uma pequena massa elevada com alopecia, em forma de botão, podendo ocorrer ulceração, sendo geralmente uma lesão única (CONCEIÇÃO e LOURES, 2016). De acordo com Patel e Forysthe (2010), o histiocitoma tende a ocorrer em cães jovens, na pina, na face ou nas extremidades distais, e geralmente sofre regressão espontânea. Muitos histiocitomas cutâneos caninos ocorrem na cabeça (TAYLOR et al., 1969). Quadros com múltiplas lesões podem ocasionalmente ocorrer e têm sido documentados em Shar-Pei Chinês (CONCEIÇÃO e LOURES, 2016).

Na histologia nota-se lâminas dérmicas infiltrativas densas e circunscritas de histiócitos homogêneos ou pleomórficos que podem se estender ao epitélio, podendo haver mitoses e infiltração linfocítica (CONCEIÇÃO e LOURES, 2016; MEDLEAU e HNILICA, 2009).

O prognóstico do histiocitoma é bom, pois a maioria dos tumores sofre resolução espontânea sem necessitar de tratamento, e as opções de tratamento incluem exérese com 
margem cirúrgica ampla ou monitoramento dos tumores enquanto se espera pela regressão espontânea (PATEL e FORYSTHE, 2010).

Segundo Pessoa et al. (2008) a avaliação imuno-histoquímica é essencial para se obter o diagnóstico definitivo. Em relação à imuno-histoquímica, os histiocitomas expressam CD1, CD11/18, CD45, classe MCH II e E-caderina (PATEL e FORYSTHE, 2010). Além disso, há também a expressão da lisozima. Um estudo concluiu que a demonstração da lisozima imunorreativa é um adjuvante útil para técnicas morfológicas convencionais para a identificação de macrófagos de tecidos, desde que seja exercido o devido cuidado na interpretação dos resultados (MOORE, 1986).

\subsection{Mastocitoma}

O mastocitoma, neoplasma de mastócitos, é o tumor cutâneo mais comum de cães (PATEL e FORYSTHE, 2010; THAMM e VAIL, 2007). Segundo Mauldin e Peters-Kennedy (2016), este tumor é responsável por 15 a $20 \%$ dos tumores de pele em cães e é o tumor maligno ou potencialmente maligno mais comum da pele. Embora sua manifestação mais comum seja na pele, há alguns casos que ocorrem envolvimento visceral (CONCEIÇÃO e LOURES, 2016).

A média de idade dos cães afetados é de aproximadamente 9 anos, e Boxer, Terrier, Boston Terrier, Labrador Retriever, Beagle e Schnauzer são as raças mais predispostas (MAULDIN e PETERS-KENNEDY, 2016). Além disso, Shar-Peis Chineses também são predispostos e, nesta raça, os mastocitomas muitas vezes ocorrem precocemente em relação a outras raças (CONCEIÇÃO e LOURES, 2016; MAULDIN e PETERS-KENNEDY, 2016). Sua distribuição anatômica compreende $50 \%$ no tronco, $40 \%$ nas extremidades e $10 \%$ na cabeça (CONCEIÇÃO e LOURES, 2016). Silva et al. (2014), que analisaram mastocitomas cutâneos em cães, observaram maior acometimento em Boxer e cães sem raça definida, e 
maior frequência em cães de 8 a 9 anos, além de observar mais acometimento na região inguinal, sendo a cabeça a região que apresentou maior grau de malignidade.

Macroscopicamente, mastocitomas têm aparência altamente variável (CONCEIÇÃO e LOURES, 2016; GOLDSCHMIDT e HENDRICK, 2002). As lesões podem ser macias a firmes, papulosas a nodulares, sésseis a pedunculosas, dérmicas ou subcutâneas, bem ou mal circunscritas, alopécicas ou não, e urticariformes (CONCEIÇÃO e LOURES, 2016). É comum a ulceração em tumores maiores. A maioria dos tumores são brancos a amarelados, mas grande parte da cor e consistência da neoplasia é dependente do grau de degranulação e da inflamação secundária que ocorre nos tumores (GOLDSCHMIDT e HENDRICK, 2002). Além disso, o histórico nos casos de mastocitomas são variáveis, em que podem se desenvolver recentemente ou em anos, podendo ter o histórico de aumento e diminuição súbitos em período de horas a dias. Alguns cães com mastocitoma podem ter o histórico de episódios repetidos de eritema e urticária ou angioedema, resultados de uma liberação massiva de mediadores vasoativos pelos mastócitos e, além disso, podem ser evidentes sinais sistêmicos, incluindo vômito, atraso na cicatrização de feridas e coagulopatias (PATEL e FORYSTHE, 2010).

Mastócitos bem diferenciados apresentam grânulos citoplasmáticos que se tornam maiores em células maturas, e esses grânulos contém numerosos constituintes bioativos, incluindo histamina e heparina, que se coram metacromaticamente pela azul de toluidina (THAMM e VAIL, 2007). Histologicamente, os mastócitos formam mantos difusos ou cordões densos de células redondas com um núcleo central redondo, citoplasma basofílico abundante e granular e membrana celular distinta (MAULDIN e PETERS-KENNEDY, 2016). Felizmente, a maioria dos mastocitomas caninos apresentam-se bem diferenciados, tornando seu diagnóstico relativamente fácil, além de que eosinófilos são quase sempre encontrados em mastocitomas caninos, às vezes podendo ser o tipo de célula predominante. 
Colagenólise, esclerose, edema, necrose e inflamação secundária são muitas vezes vistos nestes tumores (GOLDSCHMIDT e HENDRICK, 2002).

Muitos trabalhos têm sugerido uma correlação entre o grau de diferenciação celular e o comportamento biológico, no qual os sistemas de classificação têm sido desenvolvidos na esperança de prognosticar estes tumores. Contudo, tentativas de avaliação do prognóstico do mastocitoma canino foram realizadas, utilizando critérios como graduação histopatológica em graus I, II e III (PATNAIK et al., 1984) e alto grau e baixo grau histológico (KIUPEL et al., 2011), mensuração da atividade proliferativa com métodos imuno-histoquímico (SIMÕES et al., 1994) e estadiamento clínico e taxa de crescimento tumoral (THAMM e VAIL, 2007). Silva et al. (2014) relataram que a classificação de Kiupet et al. (2011) aparenta gerar menor divergência nos diagnósticos, demonstrando-se um método simples e eficaz para a avaliação histopatológica do mastocitoma. Entretanto, o fator mais importante em relação ao prognóstico é o grau histológico do tumor, e a excisão cirúrgica é o tratamento mais bemsucedido no tratamento do mastocitoma canino (PATEL e FORYSTHE, 2010). De acordo com Misdorp (2004), a graduação histológica (II ou III) e estadiamento clínico juntamente com os parâmetros cinéticos e raça (Boxers têm tumores relativamente benignos) são parâmetros importantes para o prognóstico. Contudo, a decisão do tratamento tem sido baseada na presença ou ausência de fatores prognósticos negativos e no estágio clínico da doença (THAMM e VAIL, 2007). Ressalta-se que a recorrência local, regional e as metástases distantes juntas com as desordens paraneoplásicas podem causar a morte dos animais (MISDORP, 2004).

Em relação à classificação, a marcação na imuno-histoquímica e outros parâmetros, Araújo (2011) que analisou 78 casos de mastocitoma canino, não observou diferenças estatisticamente significantes entre os graus histológicos e aos padrões KIT, nem como foram observadas diferenças estatísticas significantes entre o tumor primário e suas metástases. 
Segundo o autor, o período médio livre de recidiva em 25 animais com mastocitoma acompanhados foi de 325 dias, independente do grau histológico, padrão KIT ou tratamento (ARAÚJO, 2011).

Um estudo analisou a correlação do mastocitoma com a resposta do c-Kit, classificação histológica e angiogênese, e observou que a expressão do receptor c-kit predominantemente difusa citoplasmática e focal paranuclear foram correlacionadas com a alta densidade microvascular, com o grau histológico III e com a maior densidade de mastócitos degranulados. Além disso, a expressão predominante da membrana celular do c-Kit se correlacionou com a baixa densidade microvascular, grau histopatológico I e II, e maior densidade de mastócitos granulados (PATRUNO et al., 2014). Contudo, este trabalho indicou uma ligação entre expressão aberrante de c-Kit, aumento da angiogênese e maior grau histopatológico.

\subsection{Plasmocitoma}

Plasmocitoma cutâneo é um neoplasma oriundo de plasmócitos comuns em cães, que usualmente são benignos. No entanto, ocorrem plasmocitomas cutâneos malignos que demonstram invasão e destruição do tecido local (MAULDIN e PETERS-KENNEDY, 2016).

As lesões ocorrem no tronco, membros, cabeça (particularmente na região externa da pina e no canal de orelha), e na cavidade oral, incluindo a gengiva e língua (JACOBS et al., 2002). De acordo com Mauldin e Peters-Kennedy (2016), o plasmocitoma cutâneo ocorre mais frequentemente em cães de meia-idade ou idosos, com uma predileção marcada para os pés, canal auditivo e boca. Um trabalho que analisou plasmocitomas caninos observou maior proporção na pele do tronco e das patas, ocorrendo mais frequentemente em Yorkshire Terreier e em machos (CANGUL et al., 2002). Gross et al. (2009) também destaca importância da localização do plasmocitoma no dígito. 
Na macroscopia, os tumores são geralmente nódulos únicos, elevados e rosas de 1 a $2 \mathrm{~cm}$ de diâmetro, e lesões ulceradas e muito maiores podem estar presentes (JACOBS et al., 2002). Pode estar associada, principalmente nos dígitos, a alopecia e ulceração (CONCEIÇÃO e LOURES, 2016).

Histologicamente, observa-se que a localização é principalmente dérmica, mas pode estender-se para o tecido subcutâneo, não havendo infiltração da epiderme (JACOBS et al., 2002). A neoplasia é composta predominantemente por células com formato que varia de redondo a poligonal, as quais se arranjam em folhetos e em ninhos intimamente empacotados (GROSS et al., 2009), e estas células redondas pleomórficas são divididas em lóbulos sólidos por estroma fibroso (MAULDIN e PETERS-KENNEDY, 2016). Este tumor não é encapsulado e apresenta pouco a acentuada heterogeneidade, sendo que alguns tumores podem mostrar frequente binucleações e multinucleações, multilobulação e cariomegalia (JACOBS et al., 2002). Plasmócitos com halos perinucleares identificáveis podem ser visíveis, principalmente na periferia (MAULDIN e PETERS-KENNEDY, 2016; MEDLEAU e HNILICA, 2009). Há autores que subclassificam o plasmocitoma de acordo com o tipo celular: maduro, hialino, partido, assíncrono, mornomorfoblásticas e polimorfoblástica (CANGUL et al., 2002).

Se diversas lesões cutâneas, linfadenopatia ou outras observações clínicas e patológicas suportarem que estas doenças sistêmicas estão presentes, então o plasmocitoma extramedular ou o mieloma múltiplo devem ser considerados, sendo o prognóstico marcadamente diferente (JACOBS et al., 2002).

O prognóstico do plasmocitoma cutâneo é bom, não sendo observadas correlações significativas entre o tipo de célula, a localização do tumor e a presença de amilóide com o prognóstico (CANGUL et al., 2002). Mesmo plasmocitomas bizarros são curados após excisão, contudo, a distinção de outros tumores é importante (MAULDIN e PETERS- 
KENNEDY, 2016). Entretanto, segundo Conceição e Loures (2016), geralmente o plasmocitoma cutâneo apresenta comportamento clínico benigno, mas os tumores digitais, quando incompletamente excisados, podem recorrer com maior gravidade.

Em relação à imuno-histoquímica, os plasmocitomas caninos expressam de formam consistente o antígeno leucocítico comum CD18, e são negativos para CD45 (Gross et al., 2009). Tem sido reportado a coloração imuno-histoquímica positiva para IgG citoplasmático (para os quais são mais positivos), IgA, e vimentina, sendo negativos para citoqueratina e S100 (JACOBS et al., 2002). Há também o anticorpo Mum-1p que é razoavelmente específico para plasmocitomas, e parece ser superior ao CD79a e CD20 (MAULDIN e PETERSKENNEDY, 2016). No trabalho de Schrenzel et al (1998) que analisou a diferenciação leucocitária de antígenos nos plasmocitomas cutâneos e orais, 80\% dos plasmocitomas caninos, as células tumorais foram capazes de expressar o antígeno CD79a (Mb-1), uma molécula de sinalização associada aos receptores dos linfócitos B.

\subsubsection{Pododermatites}

A pododermatite em cães é uma afecção comum (BREATHNACH et al., 2008; WHITE, 1989). A acurácia do diagnóstico é essencial para um tratamento satisfatório ou para o controle da condição. O exame físico tem que incluir a procura por lesões em outros locais do corpo e com determinação de quantas patas estão afetadas, e o teste de diagnóstico deve incluir esfregaços de pele profundos, cultura de dermatófitos e esfregaço corado de qualquer conteúdo de exsudato ou pústula (WHITE, 1989).

Na realidade da clínica prática, grande parte das pododermatites em cães é causada por alergias, piodermas, demodicoses ou pênfigos, aproximadamente nesta ordem (WHITE, 1989).

Breathnach et al. (2008) resumiram em uma tabela as causas infecciosas e não infecciosas associadas a pododermatites em cães. Dentre as condições infecciosas havia 
dermatite bacteriana, dermatofitose, dermatite por Malassezia, micoses intermediárias ou profundas, demodicoses, infestação por Neotrombicula, dermatite por Pelodera, dermatite por ancilostomíase e leishmaniose. No mesmo trabalho, em relação as doenças não infecciosas associadas a pododermatites em cães, havia as doenças por hipersensibilidade (dermatites atópicas ou alérgicas por contato, e hipersensibilidade a alimentos, drogas, bacteriana e fúngica), doenças psicogênicas e neurológicas (dermatite acral por lambedura e síndrome da mutilação acral), doenças autoimunes (complexo pênfigo, pênfigo bolhoso, lúpus eritematoso sistêmico, lúpus eritematoso discoide e doença por aglutinação ao frio) e as causas de hiperqueratose e dermatoses nodular e pigmentar (dermatose responsiva ao zinco, hiperqueratose digital, piogranuloma estéril, síndrome dermatofibrose nodular e neoplasias) (BREATHNACH et al., 2008).

Em relação a distúrbios que acometem especificamente a bainha da unha, observa-se a onicodistrofia, que se refere à formação anormal da garra (unha), a onicomadese, no qual há perda da unha, e a paroníquia, a inflamação da pele da dobra da unha, sendo condições raras. A onicodistrofia e a paroníquia de várias unhas, em várias patas, tem uma variedade de causas, inclusive infecções localizadas (por ex., bactérias e fungos), distúrbios imunomediados (por ex., pênfigo e lúpus eritematoso), doença sistêmica (por ex., hiperadrenocorticismo e coagulação intravascular disseminada) e distúrbios de causa desconhecida (por ex., onicodistrofia lupoide, onicodistrofia idiopática), e o diagnóstico pode exigir a amputação da terceira falange e da pele adjacente proximal à dobra da unha para avaliação histopatológica (HARGIS e GINN, 2013).

A seguir serão resumidas as doenças encontradas no presente trabalho ou que apresentem grande importância na clínica de pequenos animais no Brasil, sendo doenças diferenciais de alterações que causem piodermites ou alterações diversas em cães. 


\subsubsection{Principais pododermatites bacterianas}

Os piodermas frequentemente envolvem as patas de cães e esta pode ser a única parte do corpo acometida, onde nódulos com ou sem fístulas podem estar presentes (WHITE, 1989). As áreas intertriginosas, como a pele interdigital, fornece um microambiente adequado para a proliferação bacteriana devido, entre outros fatores, aos efeitos de maior umidade e maceração das camadas mais externas do estrato córneo (PATEL e FORYSTHE, 2010).

A pododermatite bacteriana é uma infecção bacteriana profunda localizada nas patas, quase sempre secundária a corpos estranhos, parasitas, fungos, hipersensibilidades, endocrinopatias, traumatismos ou dermatites autoimunes e imunomediadas (MEDLEAU e HNILICA, 2009). Staphylococcus pseudintermedius é o principal agente bacteriano isolado em cães come piodermites, infecções de ouvido e feridas (MAULDIN e PETERSKENNEDY, 2016). Em relação especificamente a região das patas, culturas bacterianas de exsudato de unha ou prega da unha, da porção proximal da camada de unha desprendida, em geral isola-se Staphylococcus, sendo comum a ocorrência de infecção bacteriana mista (MEDLEAU e HNILICA, 2009).

Segundo Medleau e Hnilica (2009), uma ou mais patas podem ser atingidas por pododermatite bacteriana, apresentando eritema interdigital, pústulas, pápulas, nódulos, bolhas hemorrágicas, fístulas, úlceras, alopecia e/ou edema, além de prurido, dor e/ou claudicação. Com frequência as unhas acometidas se quebram e notam-se exsudação, paroníquia, edema digital e dor, sendo que a unha pode se desprender, e quando várias unhas são lesionadas, é possível verificar febre e depressão. Pode haver linfadenomegalia regional e osteomielite como sequela de infecção crônica (MEDLEAU e HNILICA, 2009).

De acordo com Medleau e Hnilica (2009), a infecção bacteriana da unha quase sempre é secundária a uma causa primária, e quando há lesão em uma unha, deve-se suspeitar de traumatismo. Contudo, em casos recorrentes de piodermites nas patas, um defeito no sistema 
imunológico pode ser suspeitado, sendo indicado o teste para hipotireoidismo e hiperadrenocorticismo (WHITE, 1989).

Há trabalhos que relatam a infecção bacteriana causada por micobactérias, como infecção por Nocardia sp., que afetam as patas (WHITE, 1989). A nocardiose é uma enfermidade cutânea que surge após a inoculação acidental de Nocardia, micro-organismo saprófita do solo, através de ferimento perfurante da pele, se manifestando como nódulos, celulite e abcessos localizados, com úlceras e fístulas que drenam uma secreção serossanguinolenta. A doença é incomum em cães mas, em geral, as lesões atingem os membros, patas ou abdômen (MEDLEAU e HNILICA, 2009).

Na histopatologia, nota-se paniculite e dermatite piogranulomatosa nodular a difusa contendo bactérias Gram-positivas, parcialmente ácido-resistentes e ramificadas no interior da lesão, podendo formar grânulos no tecido (MEDLEAU e HNILICA, 2009).

\subsubsection{Principais pododermatites fúngicas}

As dermatofitoses são infecções fúngicas da pele, unha e pelos de animais domésticos, causados por fungos taxonomicamente relacionados, conhecidos como dermatófitos, e que incluem os gêneros patogênicos Epidermophyton, Microsporum e Trichophyton (HARGIS e GINN, 2013). A face e os membros torácicos são os locais acometidos com mais frequência, visto que essas regiões interagem com o meio ambiente de maneira mais proeminente (GROSS et al., 2009). Os produtos elaborados pelos dermatófitos causam irritação dérmica e agressão a epiderme, resultando em hiperplasia epidérmica e inflamação dérmica (HARGIS e GINN, 2013).

Em especial, a infecção da unha por fungos é causada por dermatófitos, embora haja relatos de casos isolados de infecção por outros fungos. Tipicamente, apenas uma ou duas unhas são infectadas, sendo que as unhas acometidas frequentemente apresentam-se friáveis e deformadas, e a ocorrência concomitante de paroníquia é comum (MEDLEAU e HNILICA, 
2009). Macroscopicamente, a tríade de alopecia com envergadura e anormalidades na unha são especialmente sugestivas de dermatofitose (WHITE, 1989).

Os achados histológicos de dermatofitose incluem acantose, hiperqueratose, foliculite neutrofílica leve a moderada e, em alguns casos, crostas serocelulares e ruptura folicular. Dermatófitos podem ser vistos no interior ou ao redor de pelos protraídos ou, ocasionalmente, livres na camada de queratina epidérmica. De acordo com os autores, denomina-se quérion a furunculose nodular ou focalmente extensiva, ensejada por dermatófitos (GROSS et al., 2009). Estas infecções são raras em cães e a paroníquia fúngica secundária é comum em cães alérgicos. Pode-se verificar dermatite generalizada, especialmente quando várias unhas são acometidas (MEDLEAU e HNILICA, 2009).

O diagnóstico destas alterações é realizado através da demonstração de fungos na cultura (WHITE, 1989). De acordo com Medleau e Hnilica (2009), da cultura de fungos de fragmentos proximais da unha, o isolado mais encontrado é o Trichophyton spp., porém pode ocorrer infecções por Microsporum spp. e, mais raramente, por fungos não-dermatófitos (Malassezia spp.).

\subsubsection{Principais pododermatites parasitárias}

As causas parasitárias de pododermatites em cães incluem Demodex canis, Pelodera, Strongyloides e ancilostomídeos (Ancyclostoma e Uncinaria spp.) (WHITE, 1989). A demodicose é um distúrbio de pele comum em cães, principalmente jovens. Vários ácaros demodécicos diferentes foram identificados em cães e Demodex canis é o mais comum. Este vive em folículos pilosos e pode ser encontrado em glândulas sebáceas (HARGIS e GINN, 2013). De acordo com Bowman et al. (2006), Demodex canis está presente, em pequeno número, na pele da maioria dos cães normais. A transmissão deste ácaro se faz por contato direto (JONES et al., 2000). 
A demodicose canina ocorre de duas formas clínicas, localizada e generalizada. A demodicose localizada no cão consiste em uma a várias pequenas áreas alopécicas, eritematosas e descamantes sobre a face ou membros torácicos (HARGIS e GINN, 2013), e a maioria dos cães se cura espontaneamente por volta dos 12 a 18 meses de idade (GROSS et al., 2009). Em contrapartida, a demodicose generalizada é uma variante grave que se instala em cães com menos de um ano de idade (GROSS et al., 2009). Segundo Patel e Forysthe (2010), tem-se acumulado evidências que suportam a probabilidade de que cães susceptíveis a sarna demodécica apresentam imunodeficiência de células $\mathrm{T}$ específicas para Demodex, de gravidade variável, que favorece a proliferação dos ácaros.

Esses ácaros escavam pelos folículos pilosos da pele, o que causa prurido intenso acompanhado de alopecia e descamação da epiderme, e a proliferação seguida de necrose do epitélio e por inflamação acentuada da derme subjacente (JONES et al., 2000). A piodermite estafilocócica concomitante é comum nos casos generalizados, desenvolvendo pústulas que se rompem e transudam (BOWMAN et al., 2006).

O envolvimento adicional das patas (pododemodicose) pode se manifestar de forma individual, em conjunto com a demodicose generalizada, ou como sequela desta, após outras regiões do corpo terem respondido à terapia antiacariana. Eritema, inchaço e piodermite secundária profunda, com formação marcante de cicatriz podem ser notados nos dígitos, nas pregas interdigitais, entre os coxins ventrais e ao redor do leito das garras (GROSS et al., 2009). De acordo com White (1989), cães mais velhos com demodicose e pioderma profundo limitados aos pés devem ser avaliados para hiperadrenocorticismo.

$\mathrm{Na}$ maioria dos casos, o diagnóstico da forma localizada ou generalizada não é problemática, visto que geralmente os ácaros são identificados por meio de raspado de pele (GROSS et al., 2009). Já em casos crônicos, raspado de pele pode não ser capaz de penetrar o 
tecido fibroso ou o granuloma que circunda o ácaro e a biópsia tem de ser utilizada como ferramenta de diagnóstico (WHITE, 1989).

$\mathrm{Na}$ microscopia, nota-se pequenos abcessos, granulomas com células gigantes, e infiltração difusa de linfócitos, podendo ter infecções piogênicas secundárias. A foliculite profunda e a dermatite são identificáveis nas secções histológicas, onde os parasitos são facilmente demonstráveis (JONES et al., 2000). Histologicamente, o Demodex spp. possuem formato de charuto, encontrados nos folículos pilosos ou nas glândulas sebáceas associadas, e em cães com sarna demodécica grave, os ácaros podem ser encontrados em linfonodos (BOWMAN et al., 2006).

Lesões por leishmaniose também podem ser observados em patas de cães. A leishmaniose é causada pelo protozoário Leishmania spp. que são flagelados que causam manifestações cutânea, mucocutânea e visceral em cães, humanos e outros mamíferos (NELSON e COUTO, 2006). A leishmaniose nos Estados Unidos, causada pelos organismos protozoários Leishmania donovani e L. tropica, foi relatado no cão como causa de pododermatite (WHITE, 1989). Os roedores e os cães são reservatórios primários da Leishmania spp., humanos e felinos são provavelmente hospedeiros acidentais, e os flebotomíneos são os vetores (NELSON e COUTO, 2006). A importância da leishmaniose visceral como zoonose, reside não somente na sua alta incidência e ampla distribuição, mas também na possibilidade de assumir formas graves e letais quando associada ao quadro de má nutrição e infecções concomitantes (GONTIJO e MELO, 2004).

Após a picada do flebotomídeo transmissor, promastigotas são fagocitadas pelos macrófagos e se disseminam através do organismo, sendo que após um período de incubação de um mês a sete anos, a forma amastigota (aflagelada) e as lesões cutâneas se desenvolvem (NELSON e COUTO, 2006). 
As lesões cutâneas causadas por Leishmania spp. são caracterizadas por hiperqueratose, úlceras mucocutâneas descamativas, espessadas e nódulos intradérmicos no focinho, pina, orelhas e coxins (NELSON e COUTO, 2006). Em um estudo europeu que analisou as lesões cutâneas de cães com leishmaniose, observou que os principais padrões dermatológicos clínicos foram dermatite esfoliativa $(90,9 \%)$, ulcerações $(63,6 \%)$, onicogrifose $(54,5 \%)$, dermatite pustular estéril (13,6\%) e paroníquia (13,6\%) (KOUTINAS et al., 1992). Todavia, as lesões que afetam as patas incluem erosões, ulcerações, eritema, envergadura e hipertrofia da unha (WHITE, 1989).

Os padrões histopatológicos mais comumente observados nas lesões cutâneas em cães com leishmaniose são perifoliculite granulomatosa e adenite sebácea $(68,2 \%)$, dermatite perivascular superficial e profunda $(54,5 \%)$ e dermatite intersticial $(50,0 \%)$ (KOUTINAS et al., 1992). Além disso, as amastigotas da Leishmania quase sempre são encontradas em macrófagos ou em outras células do sistema reticuloendotelial da pele, medula óssea e em órgãos viscerais como o baço (BOWMAN et al., 2006). Um trabalho que analisou as lesões cutâneas em cães com leishmaniose, o agente foi detectado nas biópsias de pele de $50 \%$ dos cães (KOUTINAS et al., 1992).

O diagnóstico pode ser feito por citologia (principalmente aspirados de linfonodo e de medula óssea), histopatologia da pele, imunofluorescência indireta ou ELISA, imunohistoquímica (biópsia cutânea), PCR (amostra de biópsia cutânea ou de medula óssea) e por cultura de tecido (MEDLEAU e HNILICA, 2009). Ressalta-se que lâminas com exsudato ou esfregaços por aposição de lesões cutâneas ou de linfonodos e aspirados de medula óssea são especialmente úteis porque a estrutura do organismo é mais facilmente visível quando comparada com a histopatologia (BOWMAN et al., 2006). 


\subsubsection{Demais causas de pododermatites de maior importância}

Reação aos corpos estranhos ocorre com certa frequência em cães, no qual essas estruturas penetrantes normalmente passam pela epiderme e se alojam na derme e no subcutâneo. A porção dorsal das pregas interdigitais é a região mais atingida por farpas de gramíneas, embora isso possa ocorrer em qualquer área corporal, entretanto apresentam incidência mais elevada no final do verão e no início do outono, em épocas secas (GROSS et al., 2009). Além disso, o trauma também pode resultar em piodermas secundárias e/ou introdução de queratina do pelo na derme, sendo comum em cães de caça que vivem em superfícies ásperas (WHITE, 1989). Nestes casos, ocorre inflamação granulomatosa ou piogranulomatosa, resultante da resposta direta do hospedeiro contra o corpo estranho em conjunto com a ação de micro-organismos carreados ao material introduzido na ferida. Tais micro-organismos incluem bactérias que costumam causar infecções secundárias, actinomicetos ou Nocardia spp., micobactérias oportunistas, fungos que causam infecções subcutâneas ou sistêmicas, dermatófitos, oomicetos (Pythium insidiosum e Lagenidium spp), além de algas aclorofiladas (Prototheca spp.) (GROSS et al., 2009).

O principal diagnóstico diferencial da reação a corpos estranhos é a furunculose interdigital (ou furunculite e furunculose podais), sendo um subgrupo de piodermite profunda de ocorrência comum em cães. Embora esta seja uma síndrome multifatorial, o trauma folicular provavelmente exerce um papel importante na gênese da afecção (GROSS et al., 2009).

A furunculose podal em cães se manifesta com pápula eritematosa única ou múltipla, nódulos firmes ou instáveis, bolhas no espaço interdigital de uma ou mais patas, e as lesões podem ser doloridas ou pruriginosas, podem ulcerar, desenvolver fístulas que drenam exsudato serossanguinolento ou purulento e, em casos crônicos, podem se tornar fibrosadas (MEDLEAU e HNILICA, 2009). Além disso, a constante lambedura promove a maceração, a 
umidificação crônica e a proliferação de bactérias e de Malassezia (GROSS et al., 2009). Na histologia, observa-se perifoliculite supurativa a piogranulomatosa, foliculite, furunculose e dermatite piogranulomatosas, nodular e difusa (MEDLEAU e HNILICA, 2009).

Outra importante alteração que ocorre nos dígitos em cães é o pênfigo foliáceo, que é a forma mais comum e mais branda do complexo pênfigo, que se desenvolve em cães de forma espontânea e como uma reação adversa à terapia medicamentosa (HARGIS e GINN, 2013). De acordo com Mauldin e Peters-Kennedy (2016), no cão os anticorpos parecem reconhecer principalmente o autoantígeno Desmogleína-1, uma glicoproteína transmembrânica desmossomal envolvida em adesões intercelulares. Esta lesão não tem predileção sexual em cães, mas é mais descrita em cães com menos de 5 anos (MAULDIN e PETERS-KENNEDY, 2016). As raças mais susceptíveis são Bearded Collie, Akita, Chow Chow, Terra Nova, Schipperke e Doberman Pinscher (JONES et al., 2000).

As lesões macroscópicas do pênfigo foliáceo consistem em vesículas transitórias que rapidamente se tornam pústulas, e que podem estar localizadas em áreas específicas da pele (nariz, orelhas, região periocular, coxins, bainhas das unhas, banda coronária) ou podem ser mais generalizadas e simétricas (HARGIS e GINN, 2013). Em cães, pode-se observar hiperqueratose e crostas nos coxins, com paroníquia (MAULDIN e PETERS-KENNEDY, 2016), e os coxins plantares apresentam-se espessados e firmes, podendo conter fendas e fissuras abertas e dolorosas (JONES et al., 2000).

O padrão histológico do pênfigo foliáceo consiste de dermatite pustular intraepidermal superficial que normalmente envolve as camadas córnea e granular (MAULDIN e PETERSKENNEDY, 2016). Contudo, observa-se acantólise subcorneal e intragranular que resulta em vesículas transitórias, pústulas com neutrófilos, menos frequentemente com eosinófilos, queratinócitos acantolíticos e crostas (HARGIS e GINN, 2013). 
Além destas alterações citadas anteriormente, qualquer condição alérgica pode causar pododermatite. Segundo White (1989), a atopia e alergia alimentar são as causas alérgicas mais comuns de pododermatite em cães e ambas as condições podem envolver apenas os pés. Já a alergia por contato é provavelmente incomum como causa de pododermatose (WHITE, 1989). A dermatite de contato alérgica consiste de doença inflamatória da pele, raramente observada em cães e gatos, causada por reação imunológica adversa a uma concentração não irritante de determinada substância agressora. Acredita-se que seja uma reação de hipersensibilidade do tipo IV ou uma reação de hipersensibilidade tardia, mediada por linfócitos, que ocorre em indivíduo previamente sensibilizado (GROSS et al., 2009). A sensibilização ocorre pelo contato direto entre o alérgeno agressor e partes relativamente glabras do corpo (pele interdigital, virilhas, axilas, genitália, focinho, orelha e períneo), e as partes mais hirsutas do corpo estão mais protegidas (JONES et al., 2000). Eritema, pápulas, alopecia e prurido são vistos nas superfícies ventrais das patas (embora não normalmente nos coxins) e, dependendo do método de contato, no dorso da pata (WHITE, 1989).

Microscopicamente, as lesões iniciais começam por áreas de espongiose que progridem para a vesiculação, necrose e infiltração da epiderme afetada por linfócitos e menor número de neutrófilos e, nos casos crônicos, pode ocorrer acantose, erosões e infecção bacteriana secundária das áreas afetadas (JONES et al., 2000). Por ser a alergia de contato uma hipersensibilidade do tipo tardia, o patch-test (teste de sensibilidade alérgica com adesivo) é geralmente necessário para o diagnóstico (WHITE, 1989).

Deve-se lembrar que dermatite de contato irritante, embora apresentem lesões macro e microscópicas semelhantes a alergia de contato, apresenta a patogênese diferente, pois a dermatite de contato irritante ocorre devido à exposição da pele a substâncias químicas irritantes que lesionam diretamente as células epidérmicas, não sendo mediadas por reação 
alérgica. Contudo, nestes casos o agente agressor é mais facilmente identificado, e as lesões tendem a ser mais doloridas e pruriginosas (JONES et al., 2000).

A dermatite acral por lambedura (granuloma de lambedura) é uma inflamação comum em cães que muitas vezes é frustrante tanto para o proprietário como para o veterinário (WHITE, 1989). Essa condição é observada inicialmente por lambedura excessiva e compulsiva de determinada parte do membro, resultando em lesão alopécica firme, ulcerativa e proliferativa. As causas são multifatoriais, e embora o estresse ambiental possa contribuir na ocorrência da doença, geralmente outros fatores são mais importantes, como hipersensibilidade, pulgas, traumatismo, reação a corpo estranho, infecção, demodicose, hipotireoidismo, neuropatia, osteopatia e artrite (MEDLEAU e HNILICA, 2009). No entanto, a grande maioria destes casos deve ser denominada idiopática, no qual tradicionalmente, estes têm sido associados a problemas comportamentais, tais como o tédio, a introdução de uma nova pessoa ou animal de estimação em casa, confinamento em uma gaiola ou canil (WHITE, 1989).

Esta dermatite é comum em cães, e em geral há uma única lesão e, ocasionalmente, múltiplas (MEDLEAU e HNILICA, 2009). As raças de grande porte, como Dobermann, Dogue Alemão, Labrador Retriever, Golden Retriever, Pastor Alemão e Boxer, e de faixa etária intermediária, são predispostas à condição (CONCEIÇÃO e LOURES, 2016).

Normalmente, uma única lesão se desenvolve na área do carpo, metacarpo, metatarso, tíbia ou rádio, sendo lesões circunscritas, sem pelos e, às vezes, ulceradas (HARGIS e GINN, 2013). Um subgrupo de foliculite bacteriana profunda e de furunculose denominado furunculose traumática se associa comumente à dermatite acral por lambedura, sendo um fator que contribui para a persistência do quadro (GROSS et al., 2009).

O caso típico de dermatite acral por lambedura demonstra, no exame histológico, superfície ulcerada ou epiderme hiperplásica, verticalização das fibras colágenas na derme 
superficial, hiperplasia anexal, infiltrado periglandular plasmocitário e, frequentemente, foliculite luminal supurativa e furunculose (CONCEIÇÃO e LOURES, 2016).

\subsubsection{Outras alterações}

\subsubsection{Acrocórdon}

Os acrocórdons ou pólipos fibroepiteliais são como tumores hiperplásicos exófitos a pedunculados relatados na pele de seres humanos e animais (BIDAUT et al., 2003). Acrocórdon, entidade também referida como etiqueta cutânea, comumente se manifesta em cães e gatos, em forma de massa únicas ou múltiplas, de formato polipoide ou filiforme, que apresentam desde alguns milímetros a quase $1 \mathrm{~cm}$ de diâmetro (GROSS et al., 2009).

Os animais afetados possuem idade mediana ou são mais velhos (GROSS et al., 2009). Embora a etiologia dessas lesões permaneça obscura, pode haver predisposição para cães Bulldog (BIDAUT et al., 2003). Normalmente as lesões se manifestam na região do tronco, mas podem também acometer os pontos de pressão, os membros e o esterno. As lesões do esterno e dos membros pode medir até $3 \mathrm{~cm}$ de comprimento por $1 \mathrm{~cm}$ de diâmetro (GROSS et al., 2009).

Histologicamente é caracterizado por parte central edematosa a fibrosa envolvida por epiderme normal a moderadamente hiperplásica (BIDAUT et al., 2003). Os acrocórdons são lesões benignas e sua excisão cirúrgica é curativa (GROSS et al., 2009).

\subsubsection{Calcinose circunscrita}

A calcificação na pele ou abaixo dela é denominada calcinose (MYERS et al., 2013). Já a calcinose circunscrita é uma forma específica de mineralização do tecido em que o cálcio é depositado como agregados nodulares amorfos nos tecidos moles da língua e no subcutâneo dos coxins de cães (HARGIS e GINN, 2013).

A calcinose circunscrita é uma síndrome incomum de mineralização ectópica, idiopática ou iatrogênica caracterizada pela deposição de sais de cálcio nos tecidos moles (TAFTI et al., 
2005). Para alguns autores, a patogênese não é definida, mas alguns casos são considerados idiopáticos, enquanto outros podem ser o resultado de trauma tecidual (HARGIS e GINN, 2013). Todavia, esses casos podem ser oriundos de foco distrófico decorrente de traumatismo local, visto que as lesões surgem sobre pontos de pressão ou em locais previamente traumatizados (GROSS et al., 2009). Além disso, alguns trabalhos na literatura relatam que a calcinose circunscrita reportada nos coxins advêm de insuficiência renal (GROSS, 1997; KOWALEWICH e HAWKINS, 1992), representada como calcificação metastática secundária à insuficiência renal.

Apesar de ser incomum em cães, apresenta maior ocorrência em animais jovens (menor que dois anos de idade) e de raças grandes (especialmente Pastor Alemão) (MEDLEAU e HNILICA, 2009). Normalmente a calcinose circunscrita se apresenta como nódulos em formato de cúpula, os quais são firmes e bem circunscritos no tecido subcutâneo (GROSS et al., 2009). Algumas lesões são livremente móveis, enquanto outras são firmemente aderidas ao tecido circundante, e as superfícies de corte da maioria das lesões têm nódulos multifocais com material semelhante a giz branco (TAFTI et al., 2005).

Em um estudo com 77 casos de calcinose circunscrita em cães, o tamanho da lesão variou entre $2 \mathrm{~mm}$ a $13 \mathrm{~cm}$ de diâmetro, com lesões predominantes entre 0,5 a $3 \mathrm{~cm}$ de diâmetro, e a maioria das lesões eram únicas (82\%), que afeteram os membros pélvicos (50\%) e a língua (23\%) (TAFTI et al., 2005). Já a calcinose por insuficiência renal costuma afetar múltiplos coxins, e nos casos que tiver esse quadro, doença renal deve ser investigada (GROSS et al., 2009).

As lesões histológicas predominantes em cães com calcinose circunscrita são estruturas císticas, únicas ou múltiplas, bem definidas contendo material amorfo a granular, levemente a intensamente basofílico, com ou sem reação granulomatosa periférica e rodeado por quantidade variável de tecido conjuntivo fibroso (TAFTI et al., 2005). Além disso, esta lesão 
na derme profunda e subcutâneo contém quantidades variáveis de linfócitos e neutrófilos (JONES et al., 2000). Em uma análise de casos crônicos de calcinose circunscrita em cães, foi observado que $5 \%$ dos casos apresentava metaplasia óssea e condroide associada à lesão (TAFTI et al., 2005).

\subsubsection{Cisto apócrino}

Os cistos apócrinos são condições não neoplásicas que se manifestam com grande frequência em cães, podendo resultar da obstrução dos ductos das glândulas sudoríparas em alguns casos, mas sua etiologia ainda é desconhecida (GROSS et al., 2009). Em cães, os cistos das glândulas sudoríparas ocorrem com mais frequência na região da cabeça, dos membros, no pescoço e na porção dorsal do tronco (GROSS et al., 2009), entretanto estes situam-se predominantemente na cabeça (MEDLEAU e HNILICA, 2009).

Os cistos apócrinos se apresentam como nódulos bolhosos, bem definidos, de aspecto tenso a flutuante, que variam de alguns milímetros a alguns centímetros de diâmetro, normalmente únicos, mas diversas lesões podem ser identificadas em um paciente. Seu conteúdo é aquoso e claro, mas algumas vezes podem assumir aspecto gelatinoso e marrom, devido a sua condensação (GROSS et al., 2009).

São observados na microscopia cisto de glândula epitriquial dilatada, único ou múltiplo, de tamanho variável, revestidos por uma ou duas camadas de epitélio secretor colunar normal ou delgado (MEDLEAU e HNILICA, 2009).

\subsubsection{Cisto folicular}

É uma estrutura cística não-neoplásica com revestimento epitelial simples, e a classificação dos cistos depende da identificação do epitélio de revestimento ou da estrutura a partir da qual o cisto surgiu (MAULDIN e PETERS-KENNEDY, 2016). Com isso, existem os cistos foliculares, sendo estes classificados de acordo com o nível do folículo piloso a partir do qual elas se desenvolvem, no qual infundibular, istmo, matriarcal e híbrido são 
nomeações utilizadas, também com base no seu revestimento epitelial e tipo de queratinização (GROSS et al., 2009; MAULDIN e PETERS-KENNEDY, 2016). Em relação a estes, o termo cisto sebáceo é comumente e incorretamente designado para os cistos foliculares em razão da natureza grumosa do conteúdo ceratináceo, que ainda é descrito em algumas literaturas humanas e veterinárias mais antigas (GROSS et al., 2009).

Os cistos foliculares ocorrem em várias espécies de animais, sendo mais comuns em cães, principalmente das raças Boxer, Shih-tzu, Schnauzer e Basset Hound (MEDLEAU e HNILICA, 2009; MAULDIN e PETERS-KENNEDY, 2016).

Macroscopicamente, esses cistos apresentam-se como nódulos únicos (podendo ser múltiplos), firmes, intradérmicos ou, ocasionalmente, subcutâneos com 0,2 a $2 \mathrm{~cm}$ de diâmetro, e lesões maiores apresentam frequência rara (GROSS et al., 2009). Em lesões antigas, a parede epitelial pode se tornar muito fina, e a ruptura pode liberar a queratina retida para estimular a inflamação dérmica piogranulomatosa (MAULDIN e PETERS-KENNEDY, 2016). As lesões em cães são mais comumente vistas na cabeça, tronco e parte proximal dos membros (MEDLEAU e HNILICA, 2009).

Histologicamente, o cisto folicular é composto por uma estrutura cística preenchida por lâminas de queratina, recobertas por epitélio escamoso, estratificado e queratinizado, lembrando que sua ruptura pode induzir a resposta piogranulomatosa ao redor (MEDLEAU e HNILICA, 2009).

\subsubsection{Comedão}

Segundo Patel e Forysthe (2010), o comedo ou comedão é uma dilatação do folículo piloso, que ocorre em virtude de bloqueio por sebo ou outros debris celulares. Esta alteração ocorre em diversos distúrbios de pele, inclusive aqueles associados a traumatismo de superfície (calo, dermatose actínica), dermatose endócrina (especialmente hiperadrenocorticismo), distúrbios de cornificação herdados ou nutricionais (seborreia 
primária, dermatose responsiva à vitamina A) e em alguns distúrbios associados à infecção folicular (especialmente demodicose) (HARGIS e GINN, 2013).

De acordo com Hargis e Ginn (2013), no comedão observa-se histologicamente um plugue de estrato córneo e sebo dentro da luz de um folículo piloso.

\subsubsection{Hamartoma}

Hamartomas são nódulos semelhantes a tumores benignos compostos de quantidade excessiva e desorganizada, ou componentes ampliados, de elementos de tecidos maduros nativos para o local em que ocorrem. O termo nevo se refere a qualquer malformação congênita da pele. Sendo assim, o termo hamartoma é mais abrangente do que o nevo, e a nomenclatura preferencial para a maioria das lesões que são considerados como malformações, congênitas ou adquiridas (MAULDIN e PETERS-KENNEDY, 2016).

Existem vários tipos de hamartomas: epidermal, folicular, fibroadnexal, sebáceo, de glândulas sudoríparas e tricofoliculoma (MAULDIN e PETERS-KENNEDY, 2016). O prognóstico é favorável, por ser uma tumoração benigna e não neoplásica.

\subsubsection{Hiperplasia sebácea}

A hiperplasia sebácea apresenta as mesmas predisposições do que adenomas e carcinomas sebáceos, podendo haver múltiplos nódulos de hiperplasia sebácea. O que difere dos demais tumores é que histologicamente a hiperplasia sebácea é composta por múltiplos lóbulos sebáceos maduros maiores, com uma única camada periférica de células germinativas basaloides e um ducto central, sem mitoses (MEDLEAU e HNILICA, 2009).

Clinicamente, é caracterizada pela extrema oleosidade do pelame e da pele subjacente. Predileções raciais sugerem haver base hereditária para a afecção, sendo sustentado pelo fato de a doença se manifestar em fases precoces da vida (GROSS et al., 2009). 


\subsubsection{Hiperqueratose}

A hiperqueratose refere-se a aumento da espessura do estrato córneo, podendo ser ortoqueratótica (sem núcleos) ou paraqueratótica (núcleos retidos). A hiperqueratose e ortoqueratose são por vezes usados como sinônimos, no qual a ortoqueratose pode ser dividido em padrão trama em cesto (o padrão normal no estrato córneo), compacto e laminado. Ortoqueratose e paraqueratose não são mutuamente exclusivas e são vistos frequentemente na mesma secção de pele hiperqueratótica (MAULDIN e PETERSKENNEDY, 2016).

Os distúrbios de queratinização podem ser primários, como na seborreia primária, mas são mais frequentemente secundários a uma variedade de fatores, como inflamação, traumatismo, distúrbios metabólicos ou nutricionais (HARGIS e GINN, 2013).

Dentre as lesões que causam hiperqueratose na região das patas, destaca-se a hiperqueratose digital, que pode ocorrer espontaneamente em alguns cães adultos (WHITE, 1989). Esta alteração também é chamada de hiperqueratose nasodigital, uma afecção idiopática, caracterizada pela formação excessiva da cornificação no nariz e no coxim plantar (GROSS et al., 2009; MEDLEAU e HNILICA, 2009). Esta alteração apresenta incidência e gravidade aumentadas com o decorrer da idade do animal, representando provavelmente uma alteração senil (GROSS et al., 2009).

Entretanto, Hargis e Ginn (2013) relatam que a hiperqueratose nasal e/ou digital possui uma variedade de causas subjacentes, inclusive doenças infecciosas (por ex., cinomose, leishmaniose), distúrbios imunomediados (por ex., pênfigo foliáceo e lúpus eritematoso), distúrbios familiares ou herdados (por ex., seborreia idiopática, hiperqueratose familiar dos coxins de Irish Terriers e Dogue de Bordeaux, ictiose, paraqueratose nasal do Retriever Labrador e acrodermatite em Bull Terrier), doenças metabólicas ou nutricionais (por ex., dermatite necrolítica superficial, dermatose responsiva a zinco), reações adversas a fármacos 
e neoplasias (por ex., linfoma cutâneo). Segundo alguns autores, em alguns casos, a causa subjacente não é determinada, e a condição é, assim, considerada idiopática (ocorrendo geralmente em cães idosos) (HARGIS e GINN, 2013).

Hiperqueratose digital excessiva pode resultar em crescimentos córneos e dor decorrente da pressão no coxim plantar adjacente (MEDLEAU e HNILICA, 2009). A formação de fissuras pode causar inflamação ou infecção secundária por bactérias ou por Malassezia (GROSS et al., 2009). Contudo, o diagnóstico é baseado na histopatologia, com a exclusão de doenças diferenciais (WHITE, 1989), e o prognóstico é bom, por ser um problema estético e normalmente é possível seu controle sintomático (MEDLEAU e HNILICA, 2009). 


\section{REFERÊNCIAS}

AFFOLTER, V.K.; MOORE, P.F. Localized and disseminated histiocytic sarcoma of dendritic cell origin in dogs. Veterinary Pathology, v. 39, p.74-83, 2002.

ARAÚJO, M. R. Estudo retrospectivo e prospectivo de tumores cutâneos em cães e diferenciação dos tumores cutâneos de células redondas pela imuno-histoquímica. Dissertação de mestrado. Belo Horizonte: Escola de Veterinária, UFMG. 102p, 2011.

AVALlONE, G.; BORACCHI, P.; STEFANELLO, D.; FERRARI, R.; REBUGHINI, A.; ROCCABIANCA, P. Canine perivascular wall tumors: high prognostic impact of site, depth, and completeness of margins. Veterinary Pathology, v. 51, p.713-721, 2014.

AVALlONE, G.; HELMBOLD, P.; CANIATTI, M.; STEFANELLO, D.; NAYAR, R.C.; ROCCABIANCA, P. The spectrum of canine cutaneous perivascular wall tumors: morphologic, phenotypic and clinical characterization. Veterinary Pathology, v. 44, p. 607620, 2007.

ÁVILA, V.P.F.; ESMERALDINO, A.T.; WITZ, M.I. Aspectos clínicos e patológicos de hemangiossarcoma em cães: estudo de 62 casos. Veterinária em Foco, v. 8, n. 2, p.197-204, 2011.

BACHA, W.J.; BACHA, L.M. Atlas colorido de histologia veterinária. 2.ed. São Paulo: Roca, 2003. 472p.

BANKS, W.J. Histologia veterinária aplicada. 2 ed. São Paulo: Manole, 1991. 629p.

BELLUCO, S.; BRISEBARD, E.; WATRELOT, D.; PILLET, E.; MARCHAL, T.; PONCE, F. Digital squamous cell carcinoma in dogs: epidemiological, histological, and imunohistochemical study. Veterinary Pathology, v. 50, n. 6, p.1078-1082, 2013.

BIDAUT, A.P.; GROSS, T.L.; NOLI, C.; WELLE, M.; SUTER, M.M. Acrochordonous plaque in two Bulldogs and a Pug dog. Veterinary Dermatology, v. 14, p. 177-179, 2003.

BOSS, G.S. Tumores de bainha de nervo periférico na pele em cães: aspectos histológicos, imuno-histoquímicos e prognóstico. Dissertação de mestrado. Universidade Federal do Rio Grande do Sul. 80p. 2013.

BOWMAN, D.D. Parasitologia veterinária de Georgis. 8. ed. Barueri, SP: Manole, 2006. 422p.

BRAGULLA, H.; BUDRAS, K.D.; MULLING, C.; REESE, S.; KÖNIG, H.E. Tegumento comum. In: KÖNIG H.E. e LIEBICH H. G. Anatomia dos animais domésticos: texto e atlas colorido. (Órgãos e sistemas, v.2). Porto Alegre: Artmed, 2002. p. 645-579. 
BREATHNACH, R.M.; FANNING, S.; MULCAHY, G.; BASSET, H.F.; JONES, B.R. Canine pododermatitis and idiopathic disease. The Veterinary Journal, v. 176, p. 146-157, 2008.

BRUDAS, K.; MCCARTHY, P. H.; FRICKE, W.; RICHTER, R. Anatomy of the Dog. 5 ed. Berlin: Schlütersche Verlagsgesell schaftmb H\& Co. 2007. 218p.

CAMARGO, L. P; CONCEIÇÃO, L. G.; COSTA, P.R.S. Neoplasias melanocíticas cutâneas em cães: estudo retrospectivo de 68 casos (1996 - 2004). Brazilian Journal of Veterinary Research and Animal Science, São Paulo, v. 45, n. 2, p. 138-152, 2008.

CANGUL, I.T.; WIJNEN, M.; GARDEREN, E.V.; INGH, T.S.G.A.M.V.D. Clinicopathological aspects of canine cutaneous and mucocutaneous plasmacytomas. Journal of Veterinary Medicine Series A, v. 49, p. 307-312, 2002.

CARLOS, C.S.; WEISBRODE, S.E. Ossos, articulações, tendões e ligamentos. In: MCGAVIN, M.D.; ZACHARY, J.F. Bases da patologia em veterinária. 5 ed. Rio de Janeiro : Elsevier. 2013. p. 923-974.

CAVALCANTI, J.N. Osteossarcoma canino: estudo histopatológico, imunoistoquímico e da atividade proliferativa. Tese de Dourado. Universidade Estadual de Campinas. 96p. 2007.

CRAIG, L.E.; DITTNER, K.E.; THOMPSON, K.G. Bones and Joints. In: Jubb, Kennedy, and Palmer's pathology of domestic animals. 6 ed. v. 1., Elsevier, 2016. p. 16-163.

CONCEIÇÃO, L.G.; LOURES, F.H. Sistema tegumentar. In: SANTOS, R.L.; ALESSI, A.C. Patologia Veterinária. São Paulo: Roca, 2 ed, 2016. p. 407-486.

DERNELL, W.S.; EHRHART, N.P.; STRAW, R.C.; VAIL D.M. Tumors of the skeletal system. In: WITHROW, S.T.; VAIL, D.M. Small animal clinical oncology. 4 ed. Saunders. 2007. p. 540-582.

DYCE, K.M.; SACK, W.O.; WESING, C.J.G. Tratado de anatomia veterinária. 2 ed. Rio de Janeiro : Guanabara Koogan. 1997. 567p.

DYCE, K.M.; SACK, W.O.; WESING, C.J.G. Tratado de anatomia veterinária. 4 ed. Rio de Janeiro : Elsevier. 2010. 856p.

EHRHART N. Soft-tissue sarcomas in dogs: A Review. Journal of the American Animal Hospital Association, v. 41, p. 241-246, 2005.

FLORES, M.M.; PANZIERA, W.; KOMMERS, G.D.; IRIGOYEN, L.F.; BARROS, C.S.L.; FIGHERA, R.A. Aspectos epidemiológicos e anatomopatológicos do hemangiossarcoma em cães: 40 casos (1965-2012). Pesquisa Veterinária Brasileira, v. 32, n. 12, p.1319-1328, 2012.

GELBERG, H.B. Sistema alimentar, peritônio, omento, mesentério e cavidade peritonial. In: MCGAVIN, M.D.; ZACHARY, J.F. Bases da patologia em veterinária. 5 ed. Rio de Janeiro: Elsevier, 2013. p. 324-460. 
GETTY, R.; SISSON, S.; GROSSMAN, J. D. Sisson e Grossman's, Anatomia dos animais domésticos. 5. ed. Rio de Janeiro : Guanabara Koogan, 2 v. 1986. 2048p.

GOLDSCHMIDT, M.H.; HENDRICK, M.J. Tumors of the skin and soft tissues. In: MEUTEN D.J. Tumors in domestic animals. 4 ed. Iowa: Iowa State Press. 2002. p. 45-118.

GONTIJO, C.M.F.; MELO, M.N. Leishmaniose Visceral no Brasil: quadro atual, desafios e perspectivas. Revista Brasileira de Epidemiologia, v. 7, n. 3, p. 338- 349, 2004.

GROSS, T. L. Calcinosis circumscripta and renal dysplasia in a dog. Veterinary Dermatology, v. 8, p. 27-32. 1997.

GROSS, T.L.; IHRKE, P.J.; WALDER, E.J; AFFOLTER, V.K. Doenças de pele do cão e do gato: diagnóstico clínico e histopatológico. 2 ed. São Paulo: Roca. 2009. 904p.

HARGIS, A.M.; GINN, P.E. O Tegumento. In: MCGAVIN M.D. e ZACHARY J.F. Bases da patologia em veterinária. 5 ed. Rio de Janeiro: Elsevier, 2013. p. 975-1087.

HENRY, C. J.; BREWER, W. G.; WHITLEY, B. J.; TYLER, J.W.; OGILVIE, G.K.; NORRIS, A.; FOX, L.E.; MORRISON, W.B.; HAMMER, A.; VAIL, D.M.; BERG, J. Canine digital tumors: a veterinary cooperative oncology group retropective study of 64 dogs. Journal of Veterinary Internal Medicine, v. 19, n. 5, p. 720-724, 2005.

INTERNATIONAL COMMITTEE ON VETERINARY GROSS ANATOMICAL NOMENCLATURE (I.C.V.G.A.N.). Nomina Anatomia Veterinaria. 5 ed. 2012. 177p.

JACOBS, R.M.; MESSICK, J.B.; VALLI, V.E. Tumors of the hemolymphatic system. In: MEUTEN D.J. Tumors in domestic animals. 4 ed. Iowa: Iowa State Press. 2002. p. 119198.

JONES, T.C.; HUNT, R.D.; KING, N.W. Patologia veterinária. 6 ed. Editora Manole, SP. 2000. 1415p.

KIUPEL, M.; WEBSTER, J. D.; BAILEY, K. L.; BEST, S.; DeLAY, J.; ETRISAC, C.J.; FITZGERALD, S.D.;GAMBLE, D.; GINN, P.E.; GOLDSCHMIDT, M.H.;HENDRICK, M.J.; HOWERTH, E.W.; JANOVITZ, E.B.; LANGOHR, I.; LENZ, S.D.; LIPSCOMB, T.P.; MILLER, M.A.; MISDORP, W.; MOROFF, S.; MULLANEY, T.P.; NEYENS, I.; O'TOOLE, D.; RAMOS-VARA, J.; SCASE, T. J.; SCHULMAN, F.Y.; SLEDGE, D.; SMEDLEY, R.C.; SMITH, K.; SNYDER, P.W.; SOUTHORN, E.; STEDMAN, N.L.; STEFICEK, B.A.; STROMBERG, P.C.; VALLI, V.E.; WEISBRODE, S.E.; YAGER, J.; HELLER, J.; MILLER, R. Proposal of a 2-Tier histologic grading system for canine cutaneous mast cell tumors to more accurately predict biological behavior. Veterinary Pathology, Washington, v. 48, n. 1, p.147-155, 2011.

KÖNIG, H.E.; LIEBICH, H.G. Anatomia dos animais domésticos: texto e atlas colorido. (Aparelho locomotor, v.1). Porto Alegre: Artmed. 2002. 269p. 
KOUTINAS, A.F.; SCOTT, D.W.; KANTOS, V.; LEKKAS, S. Skin lesions in canine leishmaniasis (kala-azar): a clinical and histopathological study on 22 spontaneous cases in Greece. Veterinary Dermatology, v. 3, n. 3, p.121-130, 1992.

KOWALEWICH, N.J.; HAWKINS, E.C. Calcinosis circumscripta involving the metatarsal region in a dog with chronic renal failure. Canadian Veterinary Journal, v. 33, p. 465-466, 1992.

KIM, A; ARIAS, G.S.; TRIGO, R.H.; MINATEL, L. Estudio retrospectivo de lesiones digitales en caninos. Libro de Resúmenes. X Reunión Argentina de Patología Veterinaria 2016 (Rapave), p. 38, 2016.

LIPTAK, J.M.; FORREST, L.J. Soft tissue sarcoma. In: WITHROW, S.T.; VAIL, D.M. Small animal clinical oncology. 4 ed. Saunders. 2007. p. 356-380.

MADRUGA, F.L. Neoplasias dos dígitos em cães. Dissertação de mestrado. Faculdade de Medicina Veterinária, Universidade Técnica de Lisboa, Lisboa. 190p. 2011.

MARINO, D.J.; MATTHIESEN, D.T.; STEFANACCI, J.D.; MOROFF, S.D. Evaluation of dogs with digit masses: 117 cases (1981-1991). Journal of the American Veterinary Medical Association (JAVMA), v. 207, n. 6, p. 726-728, 1995.

MAULDIN, E.A.; PETERS-KENNEDY, J. Integumentary system. In: Jubb, Kennedy, and Palmer's Pathology of domestic animals. v. 1, 6 ed, Elsevier, 2016. p. 509-736.

MEDLEAU, L.; HNILICA, K.A. Dermatologia de pequenos animais: atlas colorido e guia terapêutico. 2 ed. São Paulo: Roca, 2009. 353p.

MISDORP, W. Mast cells and canine mast cell tumors. A review. Veterinary Quartely, v. 26, n. 4, p. 156-169, 2004.

MOORE, P.F. Characterization of cytoplasmic lysozyme immunoreactivity as a histiocytic marker in normal canine tissues. Veterinary Pathology, v. 23, p. 763-769, 1986.

MOURA, I.C. Carcinoma espinocelular cutâneo em cães. Dissertação de mestrado. Faculdade de Medicina Veterinária, Universidade Técnica de Lisboa. Lisboa. 87 p. 2012.

MYERS, R.K.; MCGAVIN, M.D.; ZACHARY, J.F. Adaptações, lesões e morte celular: bases morfológicas, bioquímicas e genéticas. In: MCGAVIN, M.D.; ZACHARY, J.F. Bases da patologia em veterinária. 5 ed. Rio de Janeiro : Elsevier. 2013. p. 2-59.

NELSON, R.W.; COUTO, C.G. Manual de medicina interna de pequenos animais. 2 ed. Rio de Janeiro: Elsevier. 2006. 1128p.

PATEL, A.; FORSYTHE, P. Dermatologia em Pequenos Animais. Elsevier, Rio de Janeiro, ed. 1, 2010. 392 p.

PATNAIK, A. K.; EHLER, W. J.; MACEWEN, E. G. Canine cutaneous mast cell tumor: morphologic grading and survival time in 83 dogs. Veterinary Pathology, New York, v. 21, n. 5, p. 469-474, 1984. 
PATRUNO, R.; MARECH, I.; ZIZZO, N.; AMMENDOLA, M.; NARDULLI, P.; GADALETA, C.; INTRONA, M.; CAPRIUOLO, G.; RUBINI, R.A.; RIBATTI, D.; GADALETA, C.D.; RANIERI, G. C-kit expression, angiogenesis, and grading in canine mast cell tumour: a unique model to study c-kit driven human malignancies. BioMed Research International, v. 2014, Article ID 730246, 8 p., 2014.

PESSOA, M.C.P.; MAIA, F.C.L.; NARDI, A.B.; PESSOA, H.F. Aspectos clínicos, diagnóstico e tratamento dos histiocitomas caninos. Medicina Veterinária, Recife, v. 2, n. 3, p. 42-53, 2008.

ROLIM, V.M.; CASAGRANDE, R.A.; WATANABE, T.T.; WOUTERS, A.T.; WOUTERS, F.; SONNE, L.; DRIEMEIER, D. Melanoma amelanóticos em cães: estudo retrospectivo de 35 casos (2004-2010) e caracterização imuno-histoquímica. Pesquisa Veteterinária Brasileira, v. 32, n. 4, p. 340-346, 2012.

ROSOLEM, M.C.; MOROZ, L.R.; RODIGHERI, S.M. Carcinoma de células escamosas em cães e gatos - Revisão de literatura. Publicações em Medicina Veterinária e Zootecnia (PUBVET), Londrina, v. 6, n. 6, Ed. 193, Art. 1299, 2012.

SANTOS, S.V. Classificação morfológica, imunoistoquímica e prognóstica dos hemangiopericitomas caninos. Dissertação de mestrado. Universidade Federal de São Paulo. Faculdade de Medicina Veterinária e Zootecnia. São Paulo. 227 p. 2005.

SCHRENZEL, M.D.; NAYDAN, D.K.; MOORE, P.F. Leukocyte differentiation antigens in canine cutaneous and oral plasmacytomas. Veterinary Dermatology, v. 9, p. 33-41, 1998.

SERAKIDES, R. Ossos e articulações. In: SANTOS, R.L.; ALESSI, A.C. Patologia Veterinária. Roca, São Paulo. 2 ed. 2016. p. 619-662.

SILVA, A.L.D.A.; QUEIROZ, R.P.; SZABÓ, M.P.J.; MEDEIROS, A.A. Grau de malignidade do mastocitoma cutâneo canino quanto à localização segundo as classificações de Patnaik et al. (1984) e Kiupel et al. (2011). Revista Brasileira de Ciência Veterinária, v. 21, n. 3, p. 183-187, 2014.

SIMÕES, J.P.C.; SCHONING, P.; BUTINE, M. Prognosis of canine mast cells tumors: a comparison of three methods. Veterinary Payhology, v. 31, n. 6, p. 637-647, 1994.

SMEDLEY, R.C.; LAMOUREUX, J.; SLEDGE, D.G.; KIUPEL, M. Immunohistochemical diagnosis of canine oral amelanotic melanocytic neoplasms. Veterinary Pathology, v. 48, p.32-40, 2011 a.

SMEDLEY, R. C.; SPANGLER, W. L.; ESPLIN, D. G.; KITCHELL, B.E.; BERGMAN, P.J.; HO, H.Y.; BERGIN, I.L.; KIUPEL, M. Prognostic markers for canine melanocytic neoplasms: a comparative review of the literature and goals for future investigation. Veterinary Pathology, v. 48, p. 54-72, 2011 b.

TAFTI, A.K.; HANNA, P.; BOURQUE, A.C. Calcinosis circumscripta in the dog: a retrospective pathological study. Journal of Veterinary Medicine Series A, v. 52, p. 13-17. 2005. 
TAYLOR, D.O.N.; DORN, C.R.; LUIS, O.H. Morphologic and biologic characteristics histiocytoma. Cancer Research, v. 29, p. 83-92, Janeiro. 1969.

THAMM, D.H. Miscellaneous tumors. In: WITHROW, S.T.; VAIL, D.M. Small animal clinical oncology. 4 ed. Saunders. 2007. p. 784-795.

THAMM, D.H.; VAIL, D.M. Mast cell tumors. In: WITHROW, S.T.; VAIL, D.M. Small Animal Clinical Oncology, 2007. p. 402-424.

THRALL, M.A. Diagnostic cytology in clinical oncology. In: WITHROW, S.T.; VAIL, D.M. Small animal clinical oncology. 4 ed. Saunders. 2007. p. 112-133.

THOMPSON, K.G.; POOL, R.R. Tumors of bones. In: MEUTEN, D.J. Tumors in domestic animals. 4 ed. Iowa : Iowa State Press. 2002. p. 245-318.

VAIL, D.M.; WITHROW, S.J. Tumors of the skin and subcutaneous tissues. In: WITHROW, S.T.; VAIL, D.M. Small animal clinical oncology. 4 ed. Saunders. 2007. p. 375-401.

WHITE, S.D. Pododermatitis. Veterinary Dermatology, v.1, p. 1-18, 1989.

WOBESER, B.K.; KIDNEY, B.A.; POWERS, B.E.; WITHROW, S.J.; MAYER, M.N.; SPINATO, M.T.; ALLEN, A.L. Diagnoses and clinical outcomes associated with surgically amputated canine digits submitted to multiple veterinary diagnostic laboratories. Veterinary Pathology, v. 44, p. 355-361, 2007. 


\title{
ARTIGo CIENTÍFICO
}

\section{Alterações Neoplásicas e não Neoplásicas das Mãos e dos Pés de Cães (2003-2016)}

Neoplastic and Non-neoplastic Lesions of the Hands and Feet of dogs (2003-2016)

\author{
Lorena Ferreira Silva ${ }^{1}$, Guilherme Reis Blume ${ }^{2}$, Jaqueline Alves de Lemos ${ }^{3}$, \\ Rômulo Santos Adjuto Eloi ${ }^{2}$, Anahí Souza Silva ${ }^{4}$, Cíntia de Lorenzo ${ }^{5}$, Luciana Sonne ${ }^{5}$, \\ Janildo Ludolf Reis $\mathrm{Jr}^{6}$ \& Fabiano José Ferreira de Sant'Ana ${ }^{7}$
}

\begin{abstract}
Background: Hands and feet of dogs are commonly affected by neoplastic and nonneoplastic lesions. These lesions can present similar clinical and gross features and sometimes the amputation of the affected region is the treatment. Main clinical signs included nodules or masses with swelling, ulcers, nails deformities, and maneness. Although some investigations detail the prevalence and the clinical and pathologic characterization of digital changes in dogs in some countries, similar studies have not been performed in Brazil. The aim of this work was to do a retrospective histopathological study to characterize the tumoriform changes of hands and feet in dogs from Brazil.
\end{abstract}

\footnotetext{
1 Programa de Pós-Graduação em Saúde Animal, área de concentração em Medicina Preventiva e Patologia Veterinária, Universidade de Brasília (UnB), Hospital Veterinário de Grandes Animais, SRB, Área Especial, Galpão 04, Granja do Torto, Brasília, DF, 70636-020. Bolsista da CAPES.

2 Laboratório Histopato Análise Anatomopatológica Veterinária. SHIS QI 29, B1. C., Subsolo Loja 41. Edifício Dom Bosco, Lago Sul, Brasília, DF, 71675-205.

3 Bolsista do Programa de Iniciação Científica (PIBIC), UnB. Hospital Veterinário de Grandes Animais, Brasília, DF.

4 Laboratório de Patologia Veterinária. UnB, Campus Universitário Darcy Ribeiro, L4 Norte, Asa Norte, Brasília, DF, 70910-900.

5 Setor de Patologia Veterinária. Universidade Federal do Rio Grande do Sul (UFRGS). Av. Bento Gonçalves, 9090, Prédio 42505, Bairro Agronomia, Porto Alegre, RS, 90650-001.

6 Curso de Medicina Veterinária, Universidade Federal de Juiz de Fora (UFJF), Av. Eugênio do Nascimento, Bom Bosco, Juiz de Fora, MG, 36038-330.

7 Laboratório de Diagnóstico Patológico Veterinário (LDPV), UnB, SRB, Área Especial, Galpão 04, Granja do Torto, Brasília, DF, 70636020. *Autor para correspondência: santanafjf@yahoo.com
} 
Materials, Methods \& Results: This study included 105 tumoriform lesions of the hands and feet of dogs sampled from 2003 to 2016. The samples are from three Brazilian veterinary diagnostic laboratories. All specimens were fixed in formalin $10 \%$, processed routinely for paraffin embedding, and stained with hematoxylin-eosin. In somes cases, additional stains, such as toluidine blue, Brown and Brenn Gram, periodic acid Schiff (PAS), Grocott Metanamine Silver (GMS), and Ziehl Neelsen, were used. Immunohistochemistry to Leishmania spp., CD117, CD79, CD3, Melan A, lysozyme, Pancytokeratin AE1/AE3, and vimentin was performed. The most frequently found lesion was neoplastic (62.9\%), followed by inflammation (19\%), and other changes (18.1\%). Among the neoplasms, $40.9 \%$ were mesenchymal, $39.4 \%$ epithelial, and $19.7 \%$ of round cells. All round cells neoplasms and the most of the epithelial and mesenchymal tumors were malignant. Female and male dogs were affected similarly. Breeds more frequently affected were Labrador Retriever, Schnauzer, Teckel, mongrel, German Shepherd, Rottweiler, and Pit Bull. Fila Brasileiro (aka Baziliam Mastiff), Pit Bull and Schnauzer were the main breeds injured by mesenchymal, epithelial, and round cells neoplasms, respectively. Labrador Retriever was the breed more diagnosed with inflammation and the other changes were observed more commonly in Teckel, Labrador Retriever, and mongrel dogs. Medium age and weight were 8.4 years and $28.5 \mathrm{~kg}$, respectively. Medium diameter of the tumoriform lesions was $2.5 \mathrm{~cm}$ and the neoplasms presented higher averages. Lesions were noted mainly in dogs with yellow coat. Most biopsies samples $(56.4 \%)$ were incisional, and amputations (85.3\%) were mostly from cases with neoplastic changes. Right forelimb was the most affected limb, and digits were the main injured anatomic structures. Squamous cell carcinoma was the most (14.2\%) commonly diagnosed neoplasm, followed by mastocytoma (7.6\%), melanoma (7.6\%), and undifferentiated sarcoma (7.6\%). In half of the inflammatory cases, the lesion was centered in hair follicle and surrounding dermis. The inflammatory infiltrate was predominantly 
piogranulomatous or lymphoplasmacytic. Follicular cyst, calcinosis circumscripta, and acrochordons were the main non neoplastic and non-inflammatory changes.

Discussion: Neoplasms (mainly malignant) correspond to approximately $62 \%$ of the tumoriform lesions of this study, followed of inflammatory alterations and other changes. Similar data were observed in previous studies performed in North America. Labrador Retriever, Schnauzer, Teckel, mongrel, German Shepherd, Rottweiler, and Pit Bull were the affected main breeds for the tumoriform lesions in this manuscript. Some authors also cite Labrador Retriever as a breed commonly affected by these lesions, whereas others investigations mention that digital tumors are frequent in large dogs. Digits were more frequently affected and squamous cell carcinoma was the most commonly diagnosed neoplasia in this retrospective investigation. Studies performed in other countries found similar results.

Keywords: diseases of dogs, dermatopathology, podology, pododermatitis, squamous cell carcinoma.

\section{INTRODUÇÃO}

As lesões tumoriformes que afetam os dígitos de cães geralmente possuem manifestação clínica semelhante [11] e, muitas vezes, podem resultar em amputação da região afetada [22]. As manifestações clínicas mais comuns são massas visíveis, muitas vezes ulceradas e com alterações das unhas, que geralmente causam claudicação [9]. Devido ao fato que frequentemente ocorre infecção secundária, neoplasmas digitais podem inicialmente ser confundidos com paroníquia crônica ou osteomielite [9,22].

Embora alguns estudos detalhem a prevalência e a caracterização clínico-patológica de alterações digitais em cães em alguns países [2,6,7,9,11], trabalhos similares não tem sido 
realizados no Brasil. Em um estudo norte-americano, foi observada prevalência alta de neoplasmas digitais em cães de grande porte (64\%), comparado com cães de médio (33\%) e de pequeno porte (12\%), além de afetar predominantemente machos (62\%). Além disso, 61\% dos casos correspondiam a neoplasias malignas, $20 \%$ neoplasias benignas e $19 \%$ se tratavam de lesões piogranulomatosas [11]. Estudos têm apontado o carcinoma de células escamosas como a neoplasia mais frequentemente diagnosticada em dígitos de cães $[6,7,11,22]$.

Devido às manifestações clínicas das lesões digitais em cães serem semelhantes, independentemente da causa, a histopatologia (eventualmente associada à imunohistoquímica) é comumente utilizada para determinar o diagnóstico e o prognóstico [22].

Assim, o presente trabalho objetiva descrever as características clínico-patológicas de 105 casos de alterações tumoriformes das mãos e pés de cães diagnosticados em três laboratórios de diagnóstico veterinário.

\section{MATERIAIS E MÉTODOS}

Foi realizado um estudo retrospectivo de lesões tumoriformes que afetaram as mãos e os pés (incluindo pele, anexos e ossos das regiões do carpo/tarso, metacarpo/metatarso e falanges) de cães, durante o período de janeiro de 2003 a julho de 2016. A pesquisa foi realizada nos arquivos do Laboratório de Patologia Veterinária da UnB (LPV-UnB), do Laboratório de Diagnóstico Patológico Veterinário da UnB (LDPV-UnB) e do Laboratório Histopato Análise Anatomopatológica Veterinária, em Brasília/DF. Todas as amostras foram fixadas em formol tamponado $10 \%$, processadas rotineiramente e coradas pela hematoxilinaeosina (HE). As lâminas foram analisadas e revisadas por três patologistas.

Foram coletadas das fichas de exames histopatológicos informações como idade, sexo, raça, pelagem, peso, histórico clínico, assim como regiões anatômicas e membros afetados, e outras alterações anatomopatológicas relacionadas à alteração das regiões supracitadas. Para 
obter o diâmetro da lesão, quando informado as três dimensões, foi calculado o volume $\left(\mathrm{cm}^{3}\right)$, logo após o raio (volume $=3 / 4 \times \pi \times$ raio $^{3}$ ), e posteriormente o diâmetro (diâmetro $=2 \times$ raio).

Com base nos diagnósticos morfológicos encontrados nas amostras, estes foram classificados em alterações neoplásicas (subclassificadas em neoplasmas de células redondas, mesenquimais ou epiteliais) e não neoplásicas (subclassificadas em inflamações e outras alterações). Na subcategoria outras alterações foram incluídas alterações não neoplásicas e não inflamatórias, como hiperplasias, cistos, calcinoses, entre outros.

Os casos de mastocitoma foram classificados histologicamente de acordo com Patnaik [15]. Quando havia suspeita desse neoplasma, os cortes eram submetidos também à coloração especial de azul de toluidina. Nas alterações inflamatórias e em algumas neoplasias foram realizadas outras colorações para melhor caracterização da lesão. Foram realizadas as colorações de Brown and Brenn Gram, periodic acid Schiff (PAS), Grocott Metanamine Silver (GMS) e Ziehl Neelsen, com o objetivo de detecção de possíveis agentes etiológicos envolvidos.

Nos neoplasmas indiferenciados ou pouco diferenciados e para pesquisa de Leishmania spp., a técnica de imuno-histoquímica (IHQ), pelo método estreptavidina-biotina peroxidase, foi utilizada para confirmar o diagnóstico. O painel de anticorpos usados encontra-se resumido na Tab. 1.

Tabela 1: Painel imuno-histoquímico utilizado, dependendo da suspeita histológica, para avaliação de lesões neoplásicas das mãos e dos pés de cães.

\begin{tabular}{ccccc}
\hline $\begin{array}{c}\text { Anticorpo } \\
\text { primário }\end{array}$ & Fonte & Clone & Diluição & Recuperação antigênica \\
\hline CD117 & Dako & Policlonal & $1: 400$ & Panela de pressão digital \\
& & & $\left(96^{\circ} \mathrm{C} / 40\right.$ min.) em \\
\hline
\end{tabular}


tampão citrato $\mathrm{pH} \mathrm{6,0}$

Panela de pressão digital

CD79

Dako

HM57

$1: 100$

$\left(96^{\circ} \mathrm{C} / 40\right.$ min.) em

tampão citrato pH 6,0

Panela de pressão digital

CD3

Dako

A0452 1:500

$\left(96^{\circ} \mathrm{C} / 40 \mathrm{~min}.\right) \mathrm{em}$

tampão citrato $\mathrm{pH}$ 6,0

Panela de pressão $\left(125^{\circ} \mathrm{C}\right.$

Pancitoqueratina

Dako

AE1/AE3 1:80

/ 7 minutos) em tampão

(CK) AE1/AE3

citrato $\mathrm{pH} 6,0$

Panela de pressão digital

Melan-A

Dako

A103

1:500

(96 ${ }^{\circ} \mathrm{C} / 40$ min.) em

tampão citrato pH 6,0

Lisozima

DakoCytomation

Policlonal

1:200

Protease XIV (Sigma

Aldrich $^{\circledR}$ ) por $15 \mathrm{~min}$.

Leishmania (L.) Soro produzido em

Policlonal 1:200

Protease XIV (Sigma

chagasi

coelho

Aldrich $^{\circledR}$ ) por $15 \mathrm{~min}$.

Panela de pressão $\left(125^{\circ} \mathrm{C}\right.$

Vimentina

Zimed

V9

$1: 200$

/ 7 minutos) em tampão

citrato $\mathrm{pH} \mathrm{6,0}$

Após incubação overnight dos cortes com anticorpo primário, foi aplicado anticorpo secundário biotinilado ligado a peroxidade (MACH 4 Univesal HRP-Polymer, Biocare Medical). A reação foi revelada com o cromógeno $\operatorname{DAB}\left(3,3^{\prime}\right.$ - diaminobenzidina), com 
exceção de Melan A onde utilizou-se 3-amino-9-etilcarbazol (AEC, DakoCytomation®). Os cortes foram contracorados com hematoxilina de Harris. Nos casos de sarcomas indiferenciados, não foi realizada IHQ para diferenciação especialmente entre fibrossarcoma, tumor de bainha de nervo periférico, leiomiossarcoma e rabdomiossarcoma. Entretanto, os casos suspeitos de sarcoma histiocítico foram investigados pela lisozima.

\section{RESULTADOS}

Foram observadas 105 alterações tumoriformes provenientes de 102 cães (Tab. 2). Dessas amostras, 66 consistiram de alterações neoplásicas (66/105, 62,9\%) e 39 eram não neoplásicas $(39 / 105,37,1 \%)$. Entre as alterações neoplásicas, 39,4\% (26/66) eram de origem epitelial, 40,9\% (27/66) de origem mesenquimal e 19,7\% (13/66) de células redondas. Dentre os neoplasmas epiteliais, $80,8 \%$ (21/26) eram malignos e 19,2\% (5/26) benignos. Dos tumores mesenquimais, $92,6 \%(25 / 27)$ eram malignos e 7,4\% (2/27) benignos, enquanto que todos os tumores de células redondas eram malignos. Considerando o número total de neoplasmas, 89,39\% (59/66) foram malignas e 10,61\% (7/66) benignas. Além disso, 20 casos eram inflamatórios $(20 / 105,19 \%)$ e 19 foram classificados como outras alterações (19/105, $18,1 \%)$

Tabela 2. Distribuição e frequência de 105 alterações tumoriformes nas mãos e nos pés de cães, quanto ao tipo de lesão e comportamento.

\begin{tabular}{cccc}
\hline Alterações & & \multicolumn{2}{c}{ Total } \\
& Malignos & Benignos & \\
\hline Neoplasmas epiteliais & $21(80,8 \%)$ & $5(19,2 \%)$ & $26(24,8 \%)$ \\
Neoplasmas mesenquimais & $25(92,6 \%)$ & $2(7,4 \%)$ & $27(25,7 \%)$ \\
Neoplasmas de células redondas & $13(100 \%)$ & - & $13(12,4 \%)$ \\
\hline
\end{tabular}




\begin{tabular}{ccc}
\hline Inflamações & n.s.a. & $20(19,0 \%)$ \\
Outras alterações & n.s.a. & $19(18,1 \%)$ \\
Total & & $105(100 \%)$ \\
\hline & & \\
\hline
\end{tabular}

Das amostras analisadas, 52 eram de fêmeas (52/105, 49,52\%), 50 de machos (50/105, 47,61\%) e em três casos, o sexo não foi informado. Entre as raças, a mais frequente foi o Labrador Retriever (12/101, 11,9\%), seguido de Schnauzer (10/101, 9,9\%), Teckel (9/101, 8,9\%), sem raça definida (SRD) $(9 / 101,8,9 \%)$, Pastor Alemão (9/101, 8,9\%), Rottweiler (9/101, 8,9\%), Pit Bull (9/101, 8,9\%), Fila (6/101, 5,9\%) e Boxer (5/101, 4,9\%). Outras dezoito raças (no total de 23 cães) foram encontradas com frequência baixa.

Relacionando o tipo da alteração com a raça, Pit Bull foi o mais afetado por neoplasmas mesenquimais $(4 / 26,15,4 \%)$, Schnauzer os que mais tiveram neoplasmas epiteliais $(5 / 25,20 \%)$ e Fila Brasileiro o mais acometido por neoplasmas de células redondas $(3 / 13,23,1 \%)$. Labrador Retriever foi a raça que mais se diagnosticou inflamações (3/19, 15,8\%), e o Teckel, Labrador Retriever e SRD os que mais tiveram outras alterações (3/18, 16,7\% cada). Com relação à idade dos cães, essa informação estava disponível em 86 casos. A média encontrada foi de 8,4 anos.

No total, foram observados três animais com até um ano de idade $(3 / 86,3,5 \%)$ e a maioria dos animais afetados eram adultos e idosos, principalmente cães com o intervalo de idade entre 6 a 12 anos (57/86, 66,3\%) (Tab. 3).

Tabela 3. Idade de 86 cães afetados por alterações tumoriformes nas mãos e nos pés (20032016).

\section{Idade (anos) Frequência}




\begin{tabular}{ccc}
\hline & $\mathbf{n}$ & $\%$ \\
$0-2$ & 3 & 3,5 \\
$2-4$ & 6 & 7,0 \\
$4-6$ & 7 & 8,1 \\
$6-8$ & 17 & 19,8 \\
$8-10$ & 16 & 18,6 \\
$10-12$ & 24 & 27,9 \\
$12-14$ & 6 & 7,0 \\
$14-16$ & 7 & 8,1 \\
Total & 86 & 100 \\
\hline
\end{tabular}

Relacionando os tipos de alterações com a idade, o grupo de alterações que obteve a menor média foi dos cães com outras alterações (7,6 anos), seguida de neoplasmas de células redondas (8,1 anos), inflamações (8,2 anos), neoplasmas mesenquimais (8,9 anos) e neoplasmas epiteliais $(9,4$ anos).

Em relação ao peso, disponível em apenas 50 casos, a média foi de $28,5 \mathrm{~kg}$. Considerando os pesos em intervalos de $5 \mathrm{~kg}$, a maior frequência de casos estava entre $5,1 \mathrm{a}$ $10 \mathrm{~kg}(9 / 50,18 \%), 35,1$ a $40 \mathrm{~kg}(9 / 50,18 \%)$ e acima de 45,1 kg (9/50, 18\%). Observou-se que a média de cães mais leves correspondia aos casos com outras alterações $(22,35 \mathrm{~kg})$ e a média de cães mais pesados eram dos casos com inflamação $(35,3 \mathrm{~kg})$.

Com relação ao tempo de evolução das lesões, essa informação estava disponível nos históricos de 53 casos. O tempo médio entre o início da lesão até a biópsia foi de nove meses. Dos 16 cães com mais de um ano de lesão, em seis foram diagnosticadas inflamações (6/16, $37,5 \%)$ 
Em relação às lesões específicas, a média estimada pelos clínicos do tempo de lesão dos neoplasmas de células redondas foi de 8,6 meses (relatado em seis casos), dos neoplasmas mesenquimais foi de 7,5 meses (informado em 16 casos), dos neoplasmas epiteliais foi de 7,3 meses (descrito em nove casos), das inflamações foi de 8,2 meses (relatado em 14 casos) e das outras alterações foi de 13,5 meses (informado em oito casos).

Foi possível definir o diâmetro médio das lesões de 77 casos, que consistiu de 2,5 cm. De forma decrescente, a média de neoplasmas mesenquimais foi a maior $(3,2 \mathrm{~cm})$, seguidas de neoplasmas de células redondas $(3 \mathrm{~cm})$, neoplasmas epiteliais $(2,2 \mathrm{~cm})$, outras alterações $(2$ cm) e inflamações $(1,6 \mathrm{~cm})$.

Em relação a cor do pelo, esse dado foi informado em apenas 46 casos $(43,8 \%)$, tendo o maior número de alterações com o pelo amarelado $(11 / 46,24,0 \%)$, com quatro casos de inflamação, dois neoplasmas epiteliais, dois neoplasmas mesenquimais e duas outras alterações, além de um neoplasma de células redondas.

Em 56,4\% dos casos (44/78), as amostras foram obtidas por biópsia incisional ou excisional sem amputação, enquanto que em 34 casos $(34 / 78,43,6 \%)$ a alteração foi obtida por amputação (usualmente parcial) do membro, na qual variavam de uma única falange (geralmente a terceira) até a amputação completa do membro. Foi observado que a maior parte das amputações $(85,3 \%)$ estava associada às neoplasias (29/34), e que 59\% das amostras provenientes de biópsia excisional sem amputação, eram alterações não neoplásicas (25/44) (Tab. 4).

Tabela 4. Quantidade de alterações tumoriformes nas mãos e nos pés de cães obtidas por biópsia com ou sem amputação.

Biópsia sem Biópsia com

Alteração 


\begin{tabular}{ccccc}
\hline & & Completa & Parcial \\
\hline Neoplasmas epiteliais & 6 & 2 & 11 & 19 \\
Neoplasmas mesenquimais & 10 & 1 & 9 & 20 \\
Neoplasmas de células redondas & 3 & 1 & 6 & 10 \\
Inflamações & 15 & - & 1 & 16 \\
Outras alterações & 10 & - & 3 & 13 \\
Total & 44 & 4 & 30 & 78 \\
\end{tabular}

Quanto ao membro acometido, 46,9\% (30/64) dos casos ocorreram em um dos membros torácicos e 53,1\% (34/64) em um dos membros pélvicos; 46\% (34/74) dos cães apresentavam a lesão do lado esquerdo e 54\% (40/74) do lado direito. Em 61 casos (61/105, $58,1 \%$ ) havia a localização anatômica completa da lesão. Assim, notou-se que as lesões estavam localizadas no membro torácico direito de 22 cães $(36,1 \%)$, seguido do pélvico esquerdo $(15 / 61,24,6 \%)$, pélvico direito $(13 / 61,21,3 \%)$ e torácico esquerdo $(11 / 61,18 \%)$. Considerando apenas os casos neoplásicos, 23 ocorreram no membro torácico $(23 / 43,53,5 \%)$ e 20 no pélvico (20/43, 46,5\%). A Tab. 5 demonstra a frequência e a localização anatômica das alterações tumoriformes. Observou-se que a maioria das lesões afetou os dígitos, seguidos do coxim, espaço interdigital e metatarso.

Tabela 5. Frequência e localização anatômica de 105 alterações tumoriformes nas mãos e nos pés de cães.

\begin{tabular}{cc}
\hline Localização & Número de casos (porcentagem) \\
\hline Dígito & $67(63,8 \%)$ \\
Coxim & $9(8,6 \%)$ \\
Espaço interdigital & $9(8,6 \%)$ \\
\hline
\end{tabular}




\begin{tabular}{cc}
\hline Metatarso & $8(7,6 \%)$ \\
Calcâneo & $4(3,8 \%)$ \\
Tarso & $4(3,8 \%)$ \\
Carpo & $3(2,9 \%)$ \\
Metacarpo & $1(0,1 \%)$ \\
\hline
\end{tabular}

Os neoplasmas epiteliais foram os mais observadas no dígito $(14 / 41,34,1 \%)$. Na região do coxim, as alterações mais comuns foram os neoplasmas de células redondas (4/9, $44,4 \%)$ e os mesenquimais $(3 / 9,33,3 \%)$. Na região interdigital, notou-se predominantemente neoplasmas mesenquimais $(4 / 9,44,4 \%)$, seguidos de inflamações e neoplasmas epiteliais $(2 / 9,22,2 \%$ cada) e de neoplasma de células redondas $(1 / 9,11,1 \%)$. Na região do metatarso, observaram-se três casos de inflamação $(3 / 8,37,5 \%)$, dois de neoplasmas epiteliais (2/8, $25,0 \%)$, dois de mesenquimais $(2 / 8,25,0 \%)$ e um de outras alterações $(1 / 8,12,5 \%)$.

Em 31 casos $(31 / 105,29,5 \%)$ foram relatados especificamente qual o dígito afetado, e em quatro casos havia acometimento de mais de um dígito. Notou-se maior acometimento do segundo (onze casos) e terceiro dígitos (oito casos), seguidos do primeiro (sete casos), do quarto e quinto dígitos (cinco casos, cada). A Tab. 6 mostra os diagnósticos morfológicos das 105 alterações, independente da região afetada. O neoplasma mais frequente foi o carcinoma de células escamosas (CCE) (14,2\%), seguido do mastocitoma, melanoma e sarcoma indiferenciado $(7,6 \%$, cada).

Tabela 6. Frequência e diagnósticos morfológicos de 105 alterações tumoriformes observadas nas mãos e nos pés de cães.

\begin{tabular}{ccc}
\hline Alteração & Frequência \\
& $\mathrm{N}$ & $\%$ \\
& & \\
\hline
\end{tabular}




\begin{tabular}{|c|c|c|}
\hline Carcinoma de células escamosas (CCE) & 15 & 14,2 \\
\hline Dermatite sem acometimento de folículos & 10 & 9,5 \\
\hline Foliculite / furunculose / perifoliculite & 10 & 9,5 \\
\hline Mastocitoma & 8 & 7,6 \\
\hline Melanoma & 8 & 7,6 \\
\hline Sarcoma indiferenciado & 8 & 7,6 \\
\hline Neoplasma de células redondas indiferenciado & 4 & 3,8 \\
\hline Cisto folicular & 4 & 3,8 \\
\hline Calcinose circunscrita & 3 & 2,9 \\
\hline Epitelioma sebáceo & 3 & 2,9 \\
\hline Osteossarcoma & 3 & 2,9 \\
\hline Sarcoma histiocítico & 3 & 2,9 \\
\hline Tricoepitelioma maligno & 2 & 1,9 \\
\hline Carcinoma de células basais & 2 & 1,9 \\
\hline Carcinoma metastático & 2 & 1,9 \\
\hline Acrocordoma & 2 & 1,9 \\
\hline Hiperqueratose & 2 & 1,9 \\
\hline Acantose com hiperqueratose & 1 & 0,9 \\
\hline Acantoma queratinizante & 1 & 0,9 \\
\hline Adenoma apócrino & 1 & 0,9 \\
\hline Adenoma sebáceo & 1 & 0,9 \\
\hline Comedo & 1 & 0,9 \\
\hline Ectasia sudorípara & 1 & 0,9 \\
\hline Fibrose & 1 & 0,9 \\
\hline Hamartoma colagenoso & 1 & 0,9 \\
\hline
\end{tabular}




\begin{tabular}{ccc}
\hline Hamartoma folicular & 1 & 0,9 \\
Hamartoma cavernoso & 1 & 0,9 \\
Hemangiopericitoma & 1 & 0,9 \\
Hemangiossarcoma & 1 & 0,9 \\
Hiperplasia sebácea & 1 & 0,9 \\
Lipoma & 1 & 0,9 \\
Plasmocitoma & 1 & 0,9 \\
Tumor de bainha de nervo periférico & 1 & 0,9 \\
Total & 105 & $\cong 100$ \\
\hline
\end{tabular}

Dos 15 cães diagnosticados com CCE, 14 eram fêmeas $(93,3 \%)$ e, dos onze animais que tiveram a idade informada, a média de idade dos cães afetados foi de 8,2 anos; as raças mais acometidas foram Rottweiler e Schnauzer, com três casos cada. Dos quatro cães que tinham lesões que acometiam mais de um dígito, dois deles tinham CCE. Em onze casos de CCE onde o membro afetado foi informado, observou-se que sete cães apresentaram o neoplasma no membro torácico (7/11), principalmente o direito $(5 / 11)$. Os dígitos foram a principal região anatômica afetada $(14 / 15)$ e apenas um caso ocorreu no coxim. As características histopatológicas incluíram múltiplos blocos ou pacotes de queratinócitos bem diferenciados e pleomórficos, invadindo acentuadamente e irregularmente a derme adjacente formando pérolas córneas características (Fig 1A-D). Áreas irregulares de necrose eram comuns. Em poucos casos indiferenciados, as células epiteliais neoplásicas foram regularmente positivas a $\mathrm{CK}$.

Os casos de melanoma ocorreram em cinco machos e três fêmeas, acometendo os dígitos $(6 / 8,75 \%)$ e o espaço interdigital $(2 / 8,25 \%)$. As raças mais afetadas foram Pastor Alemão e Rottweiler (dois casos, cada). A idade média dos cães acometidos foi 8,7 anos. Nos 
cinco casos onde o membro afetado foi informado, notou-se distribuição uniforme de acometimento. Histologicamente, notou-se proliferação de feixes de células fusiformes pleomórficas, regularmente contendo pigmentos amarronzados citoplasmáticos, que expandia a derme superficial e profunda. Um caso foi de melanoma amelanótico (Fig.2A) e o diagnóstico foi confirmado pela IHQ com reação positiva ao Melan-A (Fig. 2B).

Nos casos de mastocitoma, machos e fêmeas foram afetados igualmente (quatro casos, cada). O grau mais comum foi o II $(6 / 8,75 \%)$, seguido de um caso de I e outro de III. Com relação à raça, dois casos foram diagnosticados em Labrador Retriever e as demais raças acometidas (Boxer, Bulldog, Beagle, Teckel, Fila e Schnauzer) tiveram um caso, cada. Dos oito casos, cinco afetaram o dígito $(5 / 8,62,5 \%)$, e os outros três casos ocorreram na região do calcâneo, espaço interdigital e coxim. O membro mais acometido por mastocitoma foi o pélvico direito $(3 / 6,50 \%)$, seguido do pélvico esquerdo $(2 / 6,33,3 \%)$ e do torácico direito $(1 / 6,16,7 \%)$. Microscopicamente, havia proliferação em manto de mastócitos (geralmente bem diferenciados) na derme superficial e profunda (Fig. 3A) com número variável de eosinófilos. Dois casos de mastocitoma, sendo um grau II e um grau III, foram negativos na coloração azul de toluidina (Fig. 3B), sendo confirmados pela IHQ na reação positiva ao CD117 (Fig. 3C-D).

Os sarcomas indiferenciados afetaram igualmente machos e fêmeas (quatro casos, cada), com idade média de 8,5 anos. As raças acometidas foram Pit Bull (dois casos), Dobermann, Schnauzer, Labrador Retriever, Rottweiler e Pastor Alemão (um caso, cada), não sendo informada a raça em um caso. Quatro casos eram localizados na região do dígito (4/8, $50 \%$ ), e os demais na região do tarso, carpo, coxim e espaço interdigital. Nos seis casos onde o membro afetado foi informado, notou-se distribuição uniforme de acometimento. Todos esses casos apresentaram proliferação neoplásica indiferenciada de feixes de células 
mesenquimais, geralmente fusiformes, dispostas em vários sentidos e com marcação imunohistoquímca positiva heterogênea para vimentina.

Três casos de sarcoma histiocítico foram confirmados, um em Teckel fêmea de 9 anos com lesão no dígito do membro pélvico, um em Pit Bull macho de 5 anos com lesão na região do metatarso do membro esquerdo e um em Boxer macho de 13 anos com lesão interdigital no membro torácico direito. Os achados histopatológicos foram semelhantes aos dos sarcomas indiferenciados incluindo proliferação adicional de células mononucleares geralmente pleomórficas com núcleo reniforme e hipocromático, algumas vezes com células multinucleadas. O diagnóstico foi realizado relacionando os achados histológicos com a marcação imuno-histoquímica positiva para lisozima.

Em quatro casos de neoplasmas indiferenciados de células redondas, a IHQ foi inconclusiva com base nos resultados negativos para CD3, CD79, CD117 e lisozima (Fig. 4). Dois destes cães eram Fila, um macho sem idade não informada e uma fêmea de 7 anos, que apresentaram a lesão no coxim, sendo que a fêmea apresentava a lesão no membro torácico direito. Os outros dois, uma Boxer fêmea de 9 anos e um Beagle macho de 2 anos, apresentaram a lesão na região da falange distal do membro pélvico direito. Em geral, muitos neoplasmas de células redondas afetaram o coxim (4/9).

Três casos de epitelioma sebáceo foram diagnosticados, afetando dois machos e uma fêmea, sendo dois SRD e um Beagle, que variavam de 7-11 anos. As lesões foram encontradas na região do dígito (membro não informado), espaço interdigital (membro torácico direito) e metatarso (membro pélvico direito).

Adicionalmente, observou-se três casos de osteossarcoma, sendo estas amostras provenientes de uma cadela adulta, SRD, com lesão no dígito, de uma cadela Teckel, de 7 anos, com lesão na falange proximal do dedo 4 do membro torácico direito, e de um Labrador Retriever macho, de 15 anos e com a lesão na falange distal do dedo 3 do membro torácico 
esquerdo. Histologicamente foi observada proliferação neoplásica de células osteoides com predomínio de matriz osteoblástica, tendo como diagnóstico a subclassificação osteoblástica (Fig. 5).

Com relação às dermatites, 50\% dos casos não acometiam o folículo piloso (10/20) e nos casos restantes notou-se foliculite, furunculose e/ou perifoliculite (10/20). Nessas alterações, somente em três casos havia apenas um tipo de célula inflamatória $(3 / 20,15,0 \%)$, e a maior parte $(17 / 20,85,0 \%)$ continha infiltrado inflamatório misto. Os infiltrados predominantes eram piogranulomatosos $(6 / 20,30 \%)$ e linfoplasmocíticos $(5 / 20,25 \%)$. Com relação à intensidade da inflamação, houve predomínio de lesão acentuada (12/20, 60,0\%), seguida de moderada $(6 / 20,30,0 \%)$ e leve $(2 / 20,10,0 \%)$. Aproximadamente $37,5 \%$ dos cães com mais de um ano de lesão foram diagnosticados com processos inflamatórios. $\mathrm{Na}$ investigação da causa da inflamação, foi possível encontrar o agente infeccioso em $20 \%$ dos casos (4/20). Em três casos foram identificados poucos agregados de bactérias cocoides gramnegativas (15\%), e em um deles havia associação dessas mesmas bactérias com organismos álcool-ácido resistentes raros (5\%), e no último caso notou-se numerosos ácaros intrafoliculares, consistentes com Demodex spp. Em um caso inflamatório com suspeita de leishmaniose, a IHQ para análise de Leishmania (L.) chagasi. foi negativa.

Por fim, no grupo outras alterações (19/105), as lesões mais comuns incluíram quatro casos de cisto folicular $(21 \%)$, três de calcinose circunscrita $(15,8 \%)$ e dois de acrocordoma e hiperqueratose (10,5\% cada) (Tab. 5).

\section{DISCUSSÃO}

Embora as alterações que afetam a pele e tecidos adjacentes de cães sejam comuns e amplamente estudadas em vários países, estudos que detalhem as características clínicopatológicas dessas lesões nas extremidades de membros torácicos e pélvicos caninas são 
escassos [2,6,7,9], especialmente no Brasil. Essas alterações são importantes pois, em muitos casos, a amputação é um tratamento comumente utilizado, especialmente nos casos neoplásicos ou não responsivos as terapias preconizadas [22].

No presente estudo, os neoplasmas (principalmente malignos) corresponderam a aproximadamente $62 \%$ das alterações tumoriformes, enquanto que os $38 \%$ restantes consistiram de percentuais semelhantes de inflamações e outras alterações. Dados similares foram observados em um trabalho que analisou 428 amostras de dígitos amputados de cães, onde notou-se frequência alta de neoplasias malignas $(53,5 \%)$ [22]. Além disso, esses autores observaram neoplasias benignas em $15,7 \%$ e inflamações em 25,5\% dos casos [22]. Em uma investigação recente que analisou alterações digitais em cães, foi observado que somente $38 \%$ das lesões eram neoplasmas malignos, $15 \%$ consistiam de lesões inflamatórias e 30\% de outras alterações [7]. Ademais, esses pesquisadores detectaram que 73\% e 62,5\% dos neoplasmas epiteliais e mesenquimais, respectivamente, eram malignos [7]. Em outro estudo que analisou 124 massas digitais, 61\% eram neoplasias malignas, 20\% eram benignas e 19\% correspondiam a inflamações piogranulomatosas [11].

Tomando por base todas as alterações tumoriformes estudadas nesse estudo, os dados indicam que não há predisposição de sexo para essas lesões, assim como já foi detectado previamente por outros autores [7]. Entretanto, considerando os grupos de alterações isoladamente, notou-se que fêmeas foram mais afetadas por neoplasmas epiteliais (20/25, $80 \%)$ e os machos por inflamações $(16 / 20,80 \%)$. Dados similares não foram observados em outros trabalhos. As principais raças afetadas por tumorações nas patas desse estudo foram Labrador Retriever, Schnauzer, Teckel, SRD, Pastor Alemão, Rottweiler e Pit Bull. Alguns autores afirmam que essas alterações são mais comuns em cães de grande porte [7], enquanto alguns pesquisadores citam Labrador Retriever [6,7] e SRD [7] como raças frequentemente acometidas por essas alterações. 
No presente estudo, a maioria dos cães afetados eram adultos a idosos com média de 8,4 anos. Outras investigações apontam faixas etárias muito similares em cães com tumorações digitais [6,9]. Uma pesquisa realizada em cães nos Estados Unidos demonstrou que neoplasias digitais malignas foram diagnosticadas mais frequentemente em animais velhos, enquanto que neoplasias benignas e inflamações piogranulomatosas foram confirmadas predominantemente em jovens [11]. Os dados do presente estudo indicam que os cães jovens apresentaram maior número de outras alterações (7,6 anos), enquanto que cães com inflamações e neoplasmas tiveram média similar de 8,2 anos. Outro trabalhou demonstrou que a média de idade de cães com amputação de dígitos por inflamação foi de 7,1 anos [22]. Na presente avaliação, cerca de $54 \%$ dos cães tinha entre 5,1 a $10 \mathrm{~kg}, 35,1$ a $40 \mathrm{~kg}$ e acima de 45,1kg (18\% para cada faixa etária), no qual os animais mais leves tinham predominantemente outras alterações e os mais pesados apresentaram inflamação. Um trabalho norte americano, avaliando 117 massas digitais em cães, verificou 55\% dos casos em indivíduos com peso superior a $30 \mathrm{~kg}$ e $33 \%$ dos casos em cães pesando entre 10 e $30 \mathrm{~kg}$ [11]. Considerando todas as alterações tumoriformes avaliadas nesse estudo, o tempo médio entre o início da lesão e a biópsia foi de nove meses. Pesquisadores norte americanos encontraram tempo médio bem inferior (4,6 semanas) [6], mas nesse trabalho foram incluídos apenas neoplasmas, o que justifica essa diferença acentuada. Como esperado, os processos neoplásicos do presente trabalho apresentaram diâmetro maior em comparação as lesões não neoplásicas, com os tumores mesenquimais sendo os maiores, seguidos dos neoplasmas de células redondas, neoplasmas epiteliais, outras alterações e processos inflamatórios. Dados semelhantes referentes às neoplasias foram encontrados previamente por outros autores [6]. Cerca de um quarto dos cães avaliados no presente estudo tinham o pelo amarelo, entretanto não é possível definir precisamente se há predisposição para maior número de alterações 
tumoriformes com esta cor. Segundo Vail e Withrow [20], 25\% dos cães com tumores malignos do leito ungueal apresentam pelagem preta.

Aproximadamante metade das amostras desse trabalho foram obtidas por biópsia excisional ou incisional, e as demais alterações por amputação, parcial ou completa. A grande maioria das neoplasias foi obtida por amputação, enquanto que 59\% das tumorações coletadas por biópsia sem amputação compreendiam alterações não neoplásicas. O tratamento de eleição para as neoplasias digitais consiste na amputação do dígito, que geralmente é reservada para situações de recorrência ou metástases, sobretudo se há evidências de comprometimento de linfonodos regionais [9]. Uma técnica eficaz que pode, em muitos casos, antever e aumentar o número de amputações com diagnóstico sugestivo ou compatível de neoplasma maligno é a citopatologia [10].

O percentual de alterações tumoriformes entre membros torácicos e pélvicos e entre os dois antímeros foi muito semelhante. As lesões ocorreram predominantemente no membro torácico direito, seguido dos pélvicos esquerdo e direito, e do torácico esquerdo. Admite-se que os tumores digitais são mais frequentes em membros torácicos [6,7,9,11,22], atingindo em alguns estudos $80 \%$ de acometimento [9]. Os fatores apontados para justificar essa hipótese são o aumento de função de suporte de peso dos membros torácicos quando comparado com os pélvicos, bem como o aumento do potencial de exposição à carcinógenos durante o comportamento de cavar [6].

A principal região anatômica afetada na presente investigação foi o dígito, principalmente por neoplasmas epiteliais. O segundo dígito foi o mais afetado, seguido do terceiro, quarto e quinto. Em outro estudo, realizado em Portugal, o terceiro e segundo dígitos também foram afetados mais frequentemente que os demais [9], enquanto que em um trabalho realizado nos Estados Unidos a distribuição das tumorações foi homogênea entre todos os dígitos, com exceção do primeiro [6]. Segundo esses pesquisadores, a frequência baixa de 
tumorações no primeiro dígito ocorre porque, usualmente essa estrutura não entra em contato com o solo, dificultando o contato com potenciais agentes cancerígenos ou evitando neoplasias associadas com traumas.

O principal neoplasma diagnosticado no presente estudo foi o $\mathrm{CCE}$, seguido do mastocitoma, melanoma e sarcoma indiferenciado. Esses dados são similares aos citados por Vail e Withrow [20], que citam que aproximadamente um terço a metade dos tumores ungueais em cães são diagnosticados como CCE, seguidos em frequência por melanomas, osteossarcomas, sarcomas e mastocitomas. O CCE correspondeu a 14,2\% de todas as alterações e a aproximadamente $25 \%$ de todos os neoplasmas desse trabalho. Esse tumor afetou predominantemente fêmeas e adultos, principalmente nos coxins do membro torácico direito. Alguns pesquisadores citam que machos são mais comumente afetados por esse tumor [9,22] enquanto que outros não apontam predileção por sexo [2]. Henry et al. [6] e Belluco et al. [2] também detectaram CCE mais comumente em cães adultos. O CCE é um neoplasma de queratinócitos que representa aproximadamente 5\% de todas as neoplasias cutâneas caninas [14]. Em outros trabalhos que também analisaram alterações digitais em cães, o CCE foi a alteração e a neoplasia maligna mais comum $[6,7,9,11,13,20,22]$, representando $47,4 \%$ de frequência entre lesões malignas digitais em um trabalho [2]. Rottweiler e Schnauzer foram as raças mais acometidas por CCE na presente investigação, como observado em outros estudos $[7,9,22]$. Em geral, o CCE subungueal afeta um único dígito, conforme visto na maioria dos casos desse trabalho. A região acometida fica edemaciada, dolorida e usualmente ulcerada, causando claudicação e deformidade da unha. Ocasionalmente, múltiplos dígitos podem ser afetados ou ser afetados em sequência em um período de anos [15]. Este fenômeno de CCEs digitais múltiplos tem sido descrito previamente em cães com pigmentação escura [6]. Belluco et al. [2] analisou que 92\% dos cães com CCE digitais tinham pelos escuros e 75,2\% pertenciam a raças grande a gigantes. Além disso, em um estudo que analisou CCE digital em 
cães, foi relatado que o membro torácico foi duas vezes mais afetado que o membro pélvico [2]. CCEs subungueais em cães são localmente invasivos e quase sempre resultam em lise óssea da terceira falange [20], como observado em alguns casos do presente estudo. Aparentemente, fatores epidemiológicos, grau histológico, índice mitótico e expressão de marcadores imuno-histoquímicos não apresentaram relação com a evolução clínica de CCE digital em cães [2].

No presente trabalho, o melanoma ocorreu similarmente em machos e fêmeas, geralmente acometendo o dígito, principalmente em adultos e as raças mais afetadas foram Pastor Alemão e Rottweiler. Algumas investigações citam que o melanoma é o segundo neoplasma maligno digital mais comum em cães $[6,9,11,13,22]$. Em um trabalho que estudou neoplasias melanocíticas cutâneas em cães, os melanomas acometeram principalmente indivíduos idosos, sem predisposição sexual, e as raças mais acometidas foram SRD, seguidas por Rottweiler, Pinscher, Cocker Spaniel e Airedale [3]. Com relação ao sexo dos cães afetados por esse neoplasma, há estudos citando predominância de machos [9] e de fêmeas [22]. Rottweiler também foi apontada como uma raça predisposta a melanoma digital [9], além do Scottish Terrier [22] e do Schnauzer [6]. Os neoplasmas melanocíticos que lesam os dígitos têm sido considerados de pior prognóstico quando comparados a outras regiões comprometidas da pele [18]. Estudos demonstram que os melanomas digitais são altamente metastáticos [11].

Os casos de mastocitoma desse estudo acometeram igualmente machos e fêmeas, e a localização digital e o grau II foram mais frequentes. No trabalho de Kim et al. [7], os graus II e I foram os mais comuns. Em outras investigações [9,22], o mastocitoma foi menos frequente em comparação ao presente estudo. Uma pesquisa apontou que as raças Labrador, Boxer, Pug, Boston Terrier e Weimaraner são predispostas a desenvolverem mastocitomas [12]. No presente trabalho, várias raças foram afetadas similarmente. 
Sarcomas de tecidos moles compreendem uma população heterogênea de tumores mesenquimais cutâneos e subcutâneos com aparência patológica e comportamento clínico similares [8]. Esse grupo de neoplasmas também foi frequente em outros estudos [22]. No presente trabalho, os sarcomas indiferenciados afetaram animais adultos, ocorreram igualmente em machos e fêmeas, semelhantes a trabalhos prévios [22]. Não foram observadas diferenças em relação ao membro afetado, mas metade dos casos ocorreu na região do dígito.

Os neoplasmas cutâneos indiferenciados de células redondas podem ter aparência morfológica similares e o diagnóstico baseado apenas na histopatologia de rotina é frequentemente desafiador. Nesse estudo, quatro casos se enquadraram nessa categoria, mesmo após a realização de IHQ para investigação de linfoma $\mathrm{T}$ ou $\mathrm{B}$, plasmocitoma, sarcoma histiocítico e mastocitoma, que resultaram negativos para todos os marcadores empregados. É possível que o tempo prolongado de fixação em formol de algumas amostras tenha dificultado a reação imuno-histoquímica para alguns marcadores [17].

Os casos inflamatórios do presente trabalho ocorreram similarmente afetando o folículo piloso e adjacências, bem como o restante da derme sem afetar essa estrutura pilosa, geralmente com infiltrado acentuado (misto, piogranulomatoso ou linfoplasmocítico). Nos poucos casos, onde pode-se identificar a etiologia do processo, foram confirmados quatro casos de infecção bacteriana e outro de demodicose. Em um estudo das alterações de pele em cães, notou-se que as inflamações, depois das neoplasias, são as doenças de pele mais frequentemente diagnosticadas pela histopatologia, com predominância de dermatites em padrão perivascular, sendo o segundo padrão histopatológico mais frequentemente encontrado o grupo da foliculite, furunculose e adenite sebácea [21]. Kim et al. [7] observaram que as lesões inflamatórias da região digital em cães mais frequentes foram furunculose interdigitais e reações a corpo estranho. Wobeser et al. [22] e Marino et al. [11] também observaram maior frequência de infiltrado piogranulomatoso em inflamações digitais de cães amputados. 
Provavelmente este elevado número de casos com inflamação acentuada pode ter sido por geralmente as biópsias serem realizadas em casos crônicos e intratáveis clinicamente. Um estudo analisou as principais dermatopatias não-tumorais em cães, que em ordem decrescente, foram: atopia, dermatite alérgica à picada de pulga, foliculite bacteriana superficial, sarna demodécica, foliculite bacteriana profunda/furunculose, sarna sarcóptica, miíase, alergia alimentar, dermatite piotraumática e malassezíase [19]. Diversas são as causas de pododermatite em cães, no qual pode ser somente um indicativo de outras doenças de base que não estão sendo caracterizadas por outros sinais mais característicos e assim dificultando o diagnóstico definitivo. Acredita-se que grande parte dos casos de inflamações nas patas apresentem causas traumáticas, principalmente devido à localização dos dígitos, com seu predomínio de infiltrado piogranulomatoso [4,13]. Entretanto, acredita-se que a frequência destas alterações inflamatórias seja maior do que o observado, pois há casos inflamatórios que são resolvidos ou diagnosticados clinicamente, não sendo necessário a realização de análise histológicas para melhor diagnóstico.

As principais lesões detectadas nesse estudo incluídas no grupo outras alterações foram cisto folicular, calcinose circunscrita, acrocordoma e hiperqueratose. Em outra investigação, as principais alterações não neoplásicas e não inflamatórias dos dígitos caninos incluíram hamartoma fibroanexal e lesões císticas derivadas da matriz ungueal ou dos folículos pilosos [7]. Entretanto, a calcinose circunscrita é frequentemente relatada no subcutâneo dos coxins de cães [5].

\section{CONCLUSÃO}

Com base nos resultados do presente trabalho, pode-se concluir que: a) os neoplasmas, principalmente mesenquimais e epiteliais, são as alterações mais comuns que afetam as mãos e pés de cães; b) não há predileção por sexo para essas lesões; c) Labrador Retriever, 
Schnauzer, Teckel, SRD, Pastor Alemão, Rottweiler e Pit Bull são as raças mais acometidas por essas alterações; d) o peso e a idade médios foi $28,5 \mathrm{~kg}$ e 8,4 anos, respectivamente; e) o tempo médio de evolução das lesões foi nove meses; f) o diâmetro médio das lesões foi 2,5 cm; g) a cor do pelo mais acometida foi a amarela; h) o membro torácico direito foi o mais afetado, principalmente no dígito (especialmente o segundo); i) o carcinoma de células escamosas foi o neoplasma mais frequente, seguido do mastocitoma, melanoma e sarcoma indiferenciado; j) metade dos casos de dermatite afetavam o folículo piloso e adjacências, predominantemente com infiltrado piogranulomatoso ou linfoplasmocítico e; k) as principais lesões incluídas no grupo outras alterações foram cisto folicular, calcinose circunscrita, acrocordoma e hiperqueratose.

Acknowledgments. The authors thank the laboratories which provide the samples used in this study.

Funding. The authors are grateful to CAPES for provide scholarships to two authors (LFS e GRB).

Declaration of interest. The authors report no conflicts of interest. All authors approved the manuscript and its submission to the journal.

\section{REFERÊNCIAS}

1. Araújo M.R. 2011. Estudo retrospectivo e prospectivo de tumores cutâneos em cães e diferenciação dos tumores cutâneos de células redondas pela imuno-histoquímica. 102f. Belo Horizonte, MG. Dissertação (Mestrado em Ciência Animal) - Programa de Pós-graduação em Cência Animal, Universidade Federal de Minas Gerais. 
2. Belluco S., Brisebard E., Watrelot D., Pillet E., Marchal T. \& Ponce F. 2013. Digital squamous cell carcinoma in dogs: epidemiological, histological, and imunohistochemical study. Veterinary Pathology. 50(6), 1078-1082.

3. Camargo L.P., Conceição L.G., Costa P.R.S. 2008. Neoplasias melanocíticas cutâneas em cães: estudo retrospectivo de 68 casos (1996 - 2004). Brazilian Journal of Veterinary Research and Animal Science. 45(2), 138-152.

4. Gross T.L., Ihrke P.J., Walder E.J \& Affolter V.K. 2009. Doenças de pele do cão e do gato: diagnóstico clínico e histopatológico. 2 ed. - São Paulo : Roca. 904p.

5. Hargis A.M. \& Ginn, P.E. 2013. O Tegumento. In: Mcgavin M.D. \& Zachary J.F. Bases da patologia em veterinária. 5 ed. Rio de Janeiro : Elsevier, pp. 975-1087.

6. Henry C.J., Brewer W.G., Whitley B.J., Tyler J.W., Ogilvie G.K., Norris A., Fox L.E., Morrison W.B., Hammer A., Vail D.M. \& Berg J. 2005. Canine digital tumors: a veterinary cooperative oncology group retropective study of 64 dogs. Journal of Veterinary Internal Medicine. 19(5): 720-724.

7. Kim A., Arias G.S., Trigo R.H. \& Minatel L. 2016. Estudio retrospectivo de lesiones digitales en caninos. In: Libro de Resúmenes of the X Reunión Argentina de Patología Veterinaria 2016 (Rapave). v.1. (Esperanza, Argentina). p. 38.

8. Liptak J.M. \& Forrest L.J. 2007. Soft tissue sarcoma. In: Withrow S.T. \& Vail D.M. Small animal clinical oncology. 4 ed. Saunders, pp. 356-380.

9. Madruga F.L. 2011. Neoplasias dos dígitos em cães. 190f. Lisboa, Portugual. Dissertação (Mestrado integrado em Medicina Veterinária). Faculdade de Medicina Veterinária, Universidade Técnica de Lisboa.

10. Magalhães A.M., Ramadinha R.R., Barros C.S.L. \& Peixoto P.V. 2001. Estudo comparativo entre citologia e histopatologia no diagnóstico de neoplasias caninas. Pesquisa Veterinária Brasileira. 21(1): 23-32. 
11. Marino D.J., Matthiesen D.T., Stefanacci J.D., Moroff S.D. 1995. Evaluation of dogs with digit masses: 117 cases (1981-1991). Journal of the American Veterinary Medical Association (JAVMA). 207(6): 726-728.

12. Melo S.R. 2013. Fatores prognósticos em mastocitoma canino: correlação entre parâmetros clínicos, histológicos, marcadores de proliferação e análise termográfica. 98f. São Paulo, SP. Dissertação (Mestrado em Clínica Cirúrgica Veterinária). Programa de Pós-Graduação em Clínica Cirurgica Veterinária e Zootecnia. Universidade de São Paulo.

13. Medleau L. \& Hnilica K.A. 2009. Dermatologia de pequenos animais: atlas colorido e guia terapêutico. 2. ed. São Paulo: Roca. 528p.

14. Moura I.C. 2012. Carcinoma espinocelular cutâneo em cães. 87f. Lisboa, Portugual. Dissertação (Mestrado Integrado em Medicina Veterinária). Faculdade de Medicina Veterinária. Universidade Técnica de Lisboa.

15. Patel A. \& Forsythe P. 2010. Dermatologia em Pequenos Animais. Elsevier, Rio de Janeiro. pp.161-168.

16. Patnaik A.K., Ehler W.J. \& Macewen E.G. 1984. Canine cutaneous mast cell tumor: morphologic grading and survival time in 83 dogs. Veterinary Pathology. 21(5): 469-474.

17. Prophet E.B., Mills B., Arrington J.B. \& Sobin L.H. 1992. Laboratory Methods in Histotecnology. Washington: Armed Fources Institute of Pathology. 275p.

18. Smedley R.C., Spangler W.L., Esplin D.G., Kitchell B.E., Bergman P.J., Ho H.Y., Bergin I.L. \& Kiupel M. 2011. Prognostic markers for canine melanocytic neoplasms: a comparative review of the literature and goals for future investigation. Veterinary Pathology. 48: 54-72. 
19. Souza T.M. 2009. Dermatopatias não-tumorais em cães: bases para diagnóstico e dados de prevalência em Santa Maria, Rio Grande do Sul (2005 - 2008). 167f. Santa Maria, RS. Dissertação (Doutorado em Patologia Veterinária). Programa de Pósgraduação em Medicina Veterinária. Universidade de Santa Maria.

20. Vail D.M. \& Withrow S.J. 2007. Tumors of the skin and subcutaneous tissues. In: Withrow S.T. \& Vail D.M. Small animal clinical oncology. 4 ed. Saunders. pp. 305320.

21. Werner J. 2002. Avaliação histopatológica das dermatopatias de pequenos animais diagnosticadas entre janeiro de 1998 e abril de 2001 em Curitiba - Paraná. 71f. Curitiba, PR. Dissertação (Mestrado em Ciências Veterinárias). Programa de Pósgradução em Ciências Veterinárias. Universidade Federal do Paraná.

22. Wobeser B.K., Kidney B.A., Powers B.E., Withrow S.J., Mayer M.N., Spinato M.T. \& Allen A.L. 2007. Diagnoses and clinical outcomes associated with surgically amputated canine digits submitted to multiple veterinary diagnostic laboratories. Veterinary Pathology. 44:355-361. 


\section{Legendas das figuras}
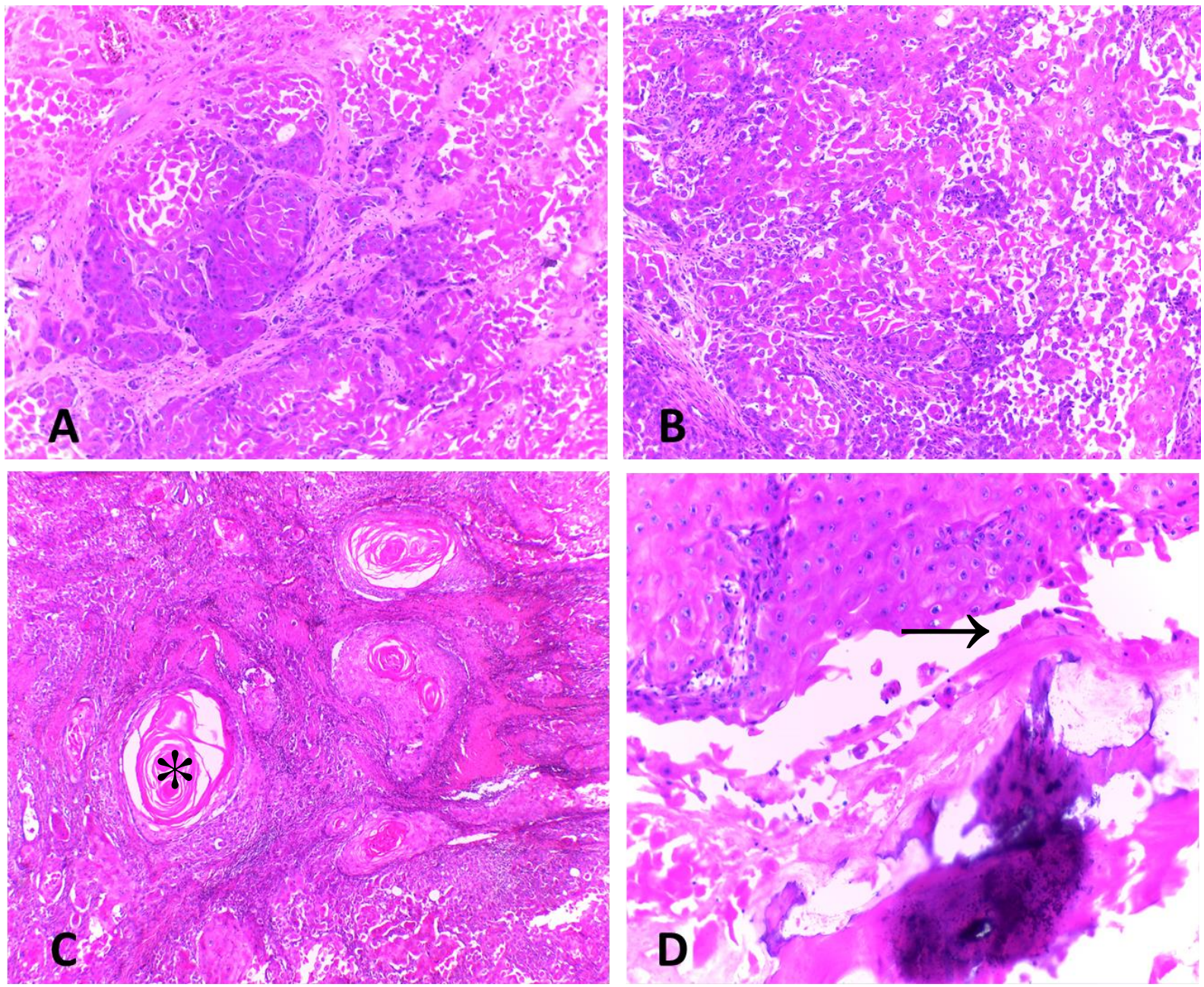

Figura 1. Histologia em $1^{\circ}$ e $2^{\circ}$ dígito de um cão, fêmea, Rottweiler, com CCE. HE. A.

Observa-se os blocos de células epiteliais em meio a pequeno estroma fibrovascular. Obj.

10X B. A neoplasia apresenta-se pleomórfica, com necrose celular moderada. Obj. 10X C.

Observa-se formação de "pérolas córneas" (asterisco) em meio a blocos de células neoplásicas. Obj. 10X D. Infiltração da neoplasia acometendo o tecido ósseo (terceira falange) (seta). Obj. 20X. 

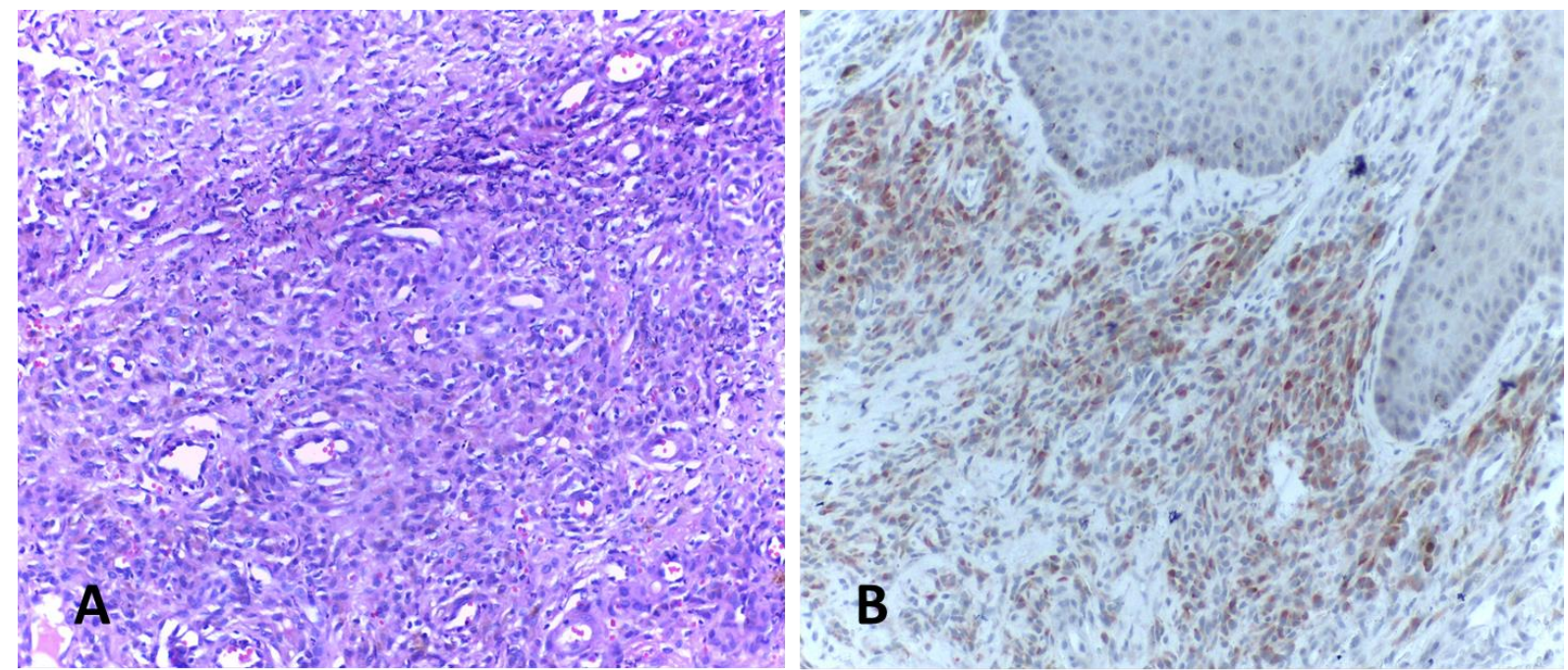

Figura 2. A. Histologia de um digito de um cão Golden, macho. A. Observa-se uma neoplasia de células mesenquimais sem pigmentação. HE, Obj, 20X. B. As células neoplásicas, predominantemente da região da derme superficial, apresentam marcação citoplasmática. Imuno-histoquímica Melan-A, cromógeno AEC. Obj. 20X. 


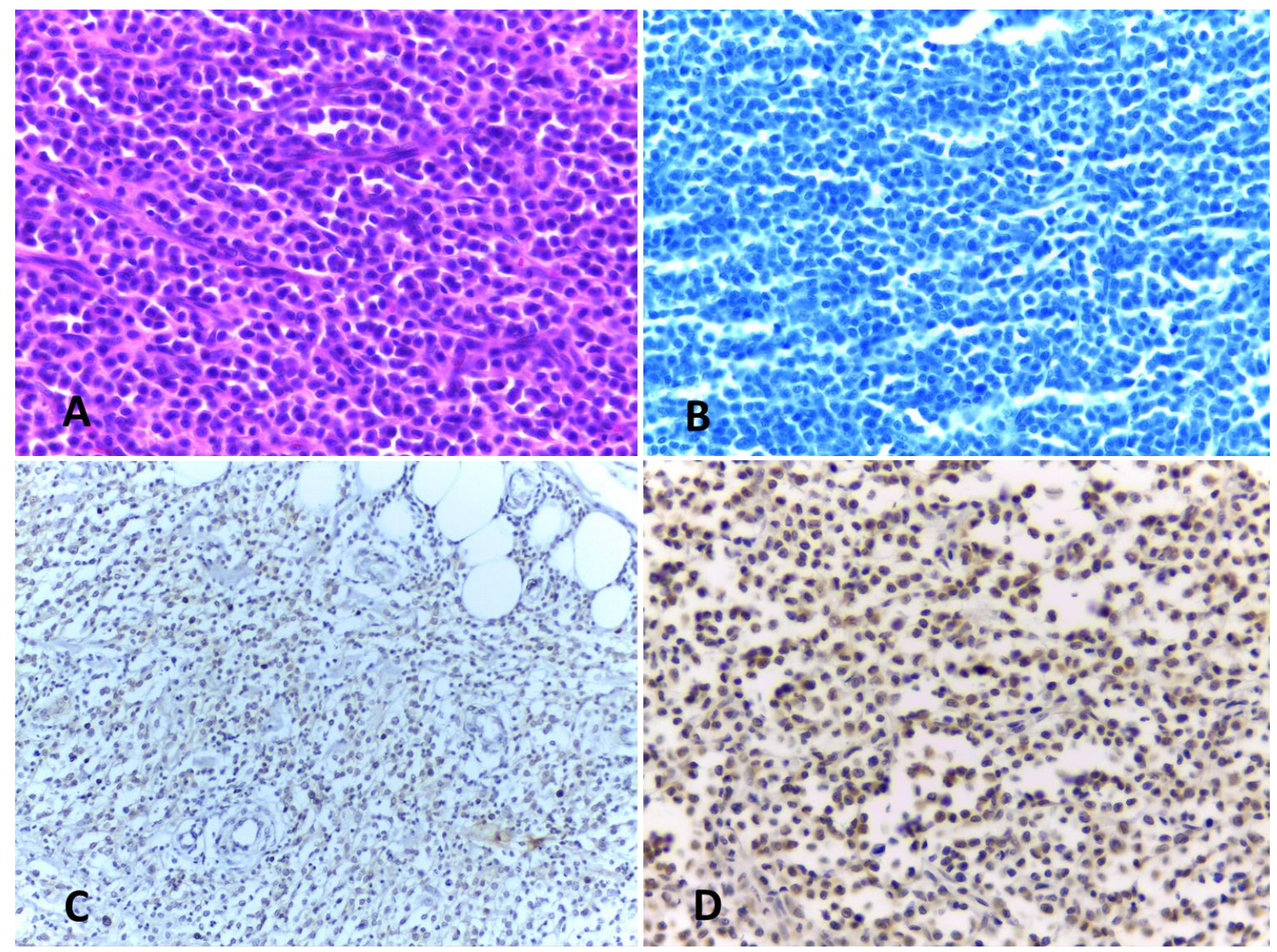

Figura 3. Aspectos histológicos e imuno-histoquímicos de mastocitoma digital afetando o dígito do membro torácico direito de um cão Bulldog, macho A. Nota-se proliferação neoplásica de células redondas, densamente celular, com ausência de grânulos citoplasmáticos. HE, Obj. 20X. B. Visualiza-se ausência de grânulos metacromáticos no citoplasma das células neoplásicas. Azul de toluidina, Obj. 20X. C e D. Observa-se células redondas neoplásicas com imunomarcação citoplasmática moderada. Imuno-histoquímica CD117, cromógeno DAB. Obj. 10X (C) e 20X (D). 


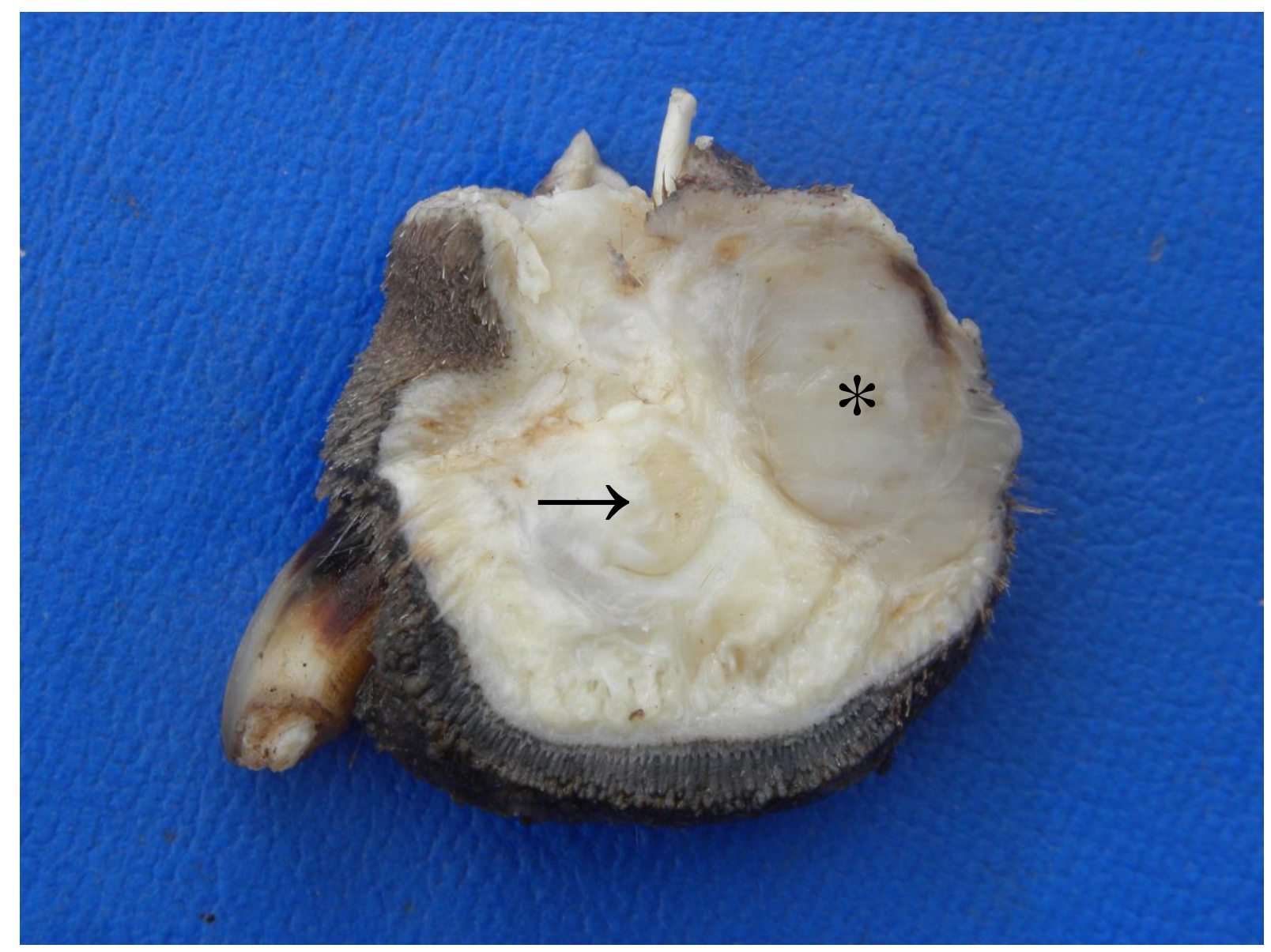

Figura 4. Neoplasma de células redondas indiferenciado diagnosticado no dígito (altura da falange distal) de uma cadela Boxer. Visualiza-se corte longitudinal de massa neoplásica esbranquiçada e moderadamente delimitada (asterisco) na região caudal do dígito, próximo a falange distal (seta). Proveniente de amputação de um dígito. 


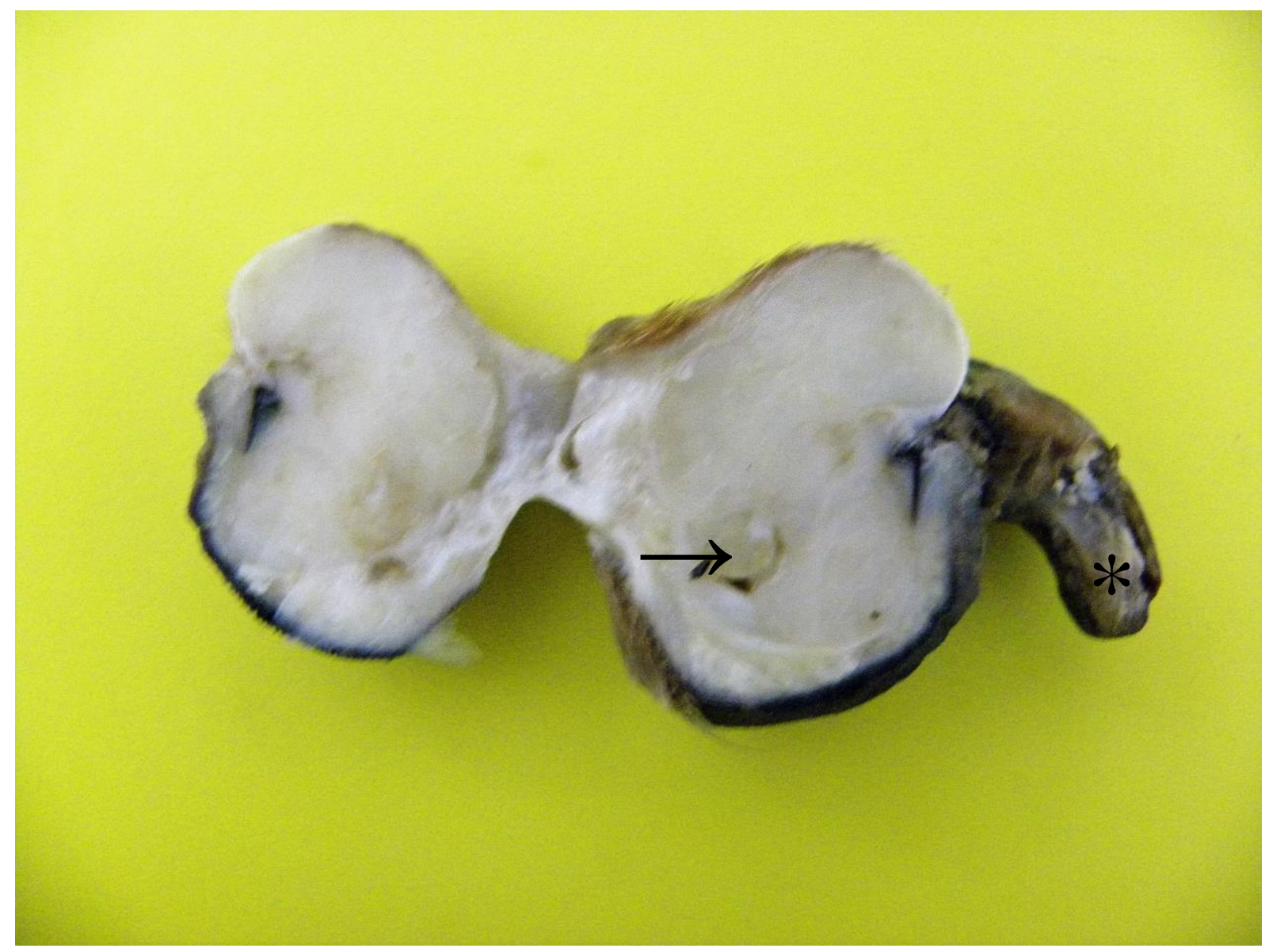

Figura 5. Osteossarcoma osteoblático digital detectado na região da falange proximal em uma cadela Tekel. Massa neoplásica esbranquiçada obtida em amputação de um dígito, cortada longitudinalmente. Nota-se a falange distal acometida pela neoplasia (seta), e a unha irregular e lascada (asterisco). 


\section{CONCLUSÕES}

Com base nos resultados do presente trabalho, pode-se concluir que:

a) os neoplasmas, principalmente mesenquimais e epiteliais, são as alterações mais comuns que afetam as mãos e pés de cães;

b) não houve predileção por sexo para essas lesões;

c) Labrador Retriever, Schnauzer, Teckel, SRD, Pastor Alemão, Rottweiler e Pit Bull são as raças mais acometidas por essas alterações;

d) o peso e a idade médios foi $28,5 \mathrm{~kg}$ e 8,4 anos, respectivamente;

e) o tempo médio de evolução das lesões foi nove meses;

f) o diâmetro médio das lesões foi $2,5 \mathrm{~cm}$;

g) a cor do pelo mais acometida foi a amarela;

h) o membro torácico direito foi o mais afetado, principalmente no dígito (especialmente o segundo);

i) o carcinoma de células escamosas foi o neoplasma mais frequente, seguido do mastocitoma, melanoma e sarcoma indiferenciado;

j) metade dos casos de dermatite afetavam o folículo piloso e adjacências, predominantemente com infiltrado piogranulomatoso ou linfoplasmocítico;

k) as principais lesões incluídas no grupo outras alterações foram cisto folicular, calcinose circunscrita, acrocordoma e hiperqueratose. 